\title{
KILLING “WOMAN": GENDER AND VIOLENCE IN SELECTED PLAYS BY SHEILA CALLAGHAN AND MARISA WEGRZYN
}

A Dissertation
presented to
the faculty of the Graduate School
at the University of Missouri - Columbia
In partial fulfillment
of the Requirement for the Degree of
Doctor of Philosophy
KATE BUSSELLE
Dr. Cheryl Black, Dissertation Supervisor
JULY 2019


The undersigned, appointed by the dean of the Graduate School, have examined the dissertation entitled

\title{
KILLING “WOMAN”: GENDER AND VIOLENCE IN SELECTED PLAYS BY SHEILA CALLAGHAN AND MARISA WEGRZYN
}

\author{
Presented by Kate Busselle, \\ a candidate for the degree of \\ Doctor of Philosophy \\ And hereby certify that, in their opinion, it is worthy of acceptance. \\ Professor Cheryl Black \\ Professor David Crespy \\ Professor Claire Syler
}

Professor Ilyana Karthas 


\section{ACKNOWLEDGEMENTS}

I would like to acknowledge the many people who have aided me in this journey to write, debate, and develop this dissertation.

I would like to thank my parents for their unyielding support and their repeated encouragement to use my Finnish roots and "sisu" through any struggles I encountered along the way.

To Dan, thank you for being my absolute rock, my number one cheerleader, and my constant reminder that if writing a dissertation was easy, then everyone would do it.

Dr. Black, I am forever in your debt and endlessly thankful for your guidance, mentorship, and friendship on this journey. You will forever be one of my favorite collaborators in scholarship and artistic practice. You held me to the highest standard and expected nothing less than the best from me and my work, and for that, I am sincerely grateful.

Dr. Crespy, Dr. Syler, and Dr. Karthas, thank you for your service, your insights, and your enthusiasm for this project. It was so refreshing to have a team of individuals who not only believed in the work I was doing but championing it and thinking of all the ways that this work could continue to grow and flourish.

To Sheila and Marisa, thank you for writing works that challenge the status quo and have inspired me, provoked my thinking, and challenged the depth and breadth of my scholarship. You two are true pioneers in feminist playwriting and I cannot wait to see what you write next.

To all my friends and colleagues, thank you for indulging me when I needed a shoulder to cry on, a second set of eyes and ears to process an idea, and 
the repeated encouraging line of "I can't wait to read your dissertation when it's done." 


\section{TABLE OF CONTENTS}

ACKNOWLEDGEMENTS .............................................................................. ii

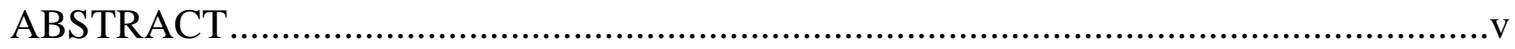

CHAPTER ONE: Introduction ...........................................................................

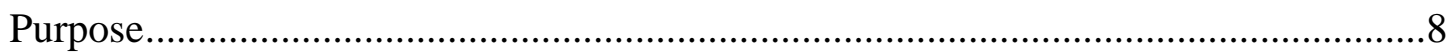

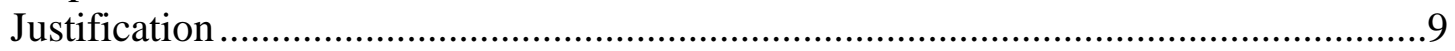

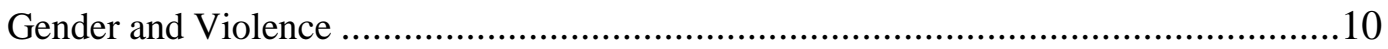

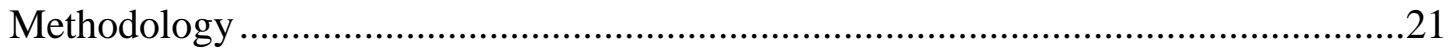

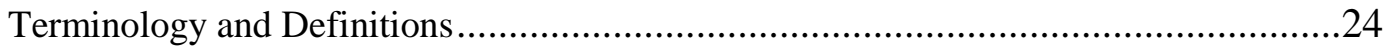

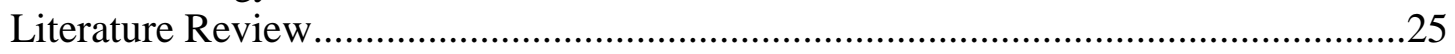

Dramatic Representations of Violence ............................................................25

Scholarship on Sheila Callaghan ....................................................................29

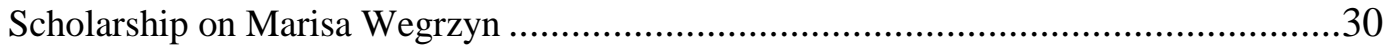

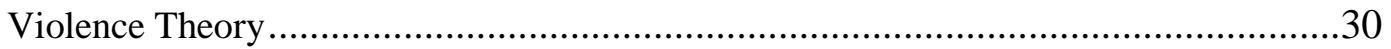

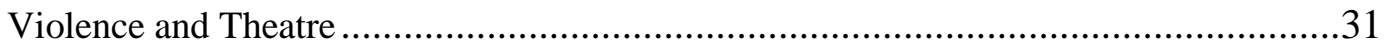

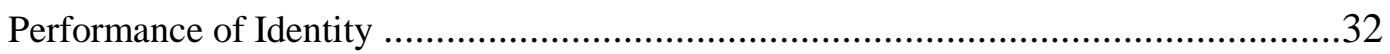

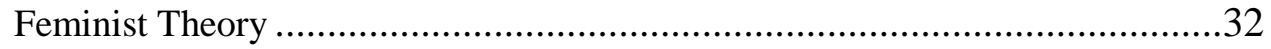

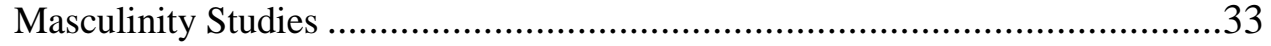

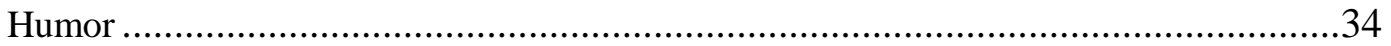

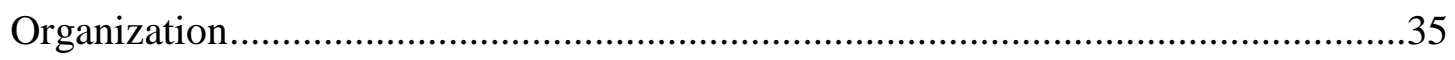

CHAPTER TWO: Roadkill Confidential: "I am the keeper of the marvel" ......................37

CHAPTER THREE: That Pretty Pretty; Or, the Rape Play: "I want to kill that pretty"..73

CHAPTER FOUR: Killing Women: "What is execution but, literally, the opposite of who we are?".

CHAPTER FIVE: The Butcher of Baraboo: "Lots of ways to kill a person..." .............150

CHAPTER SIX: Conclusion: “That's some subversive shit right there.”.....................181

Summary of Findings................................................................................ 182

Staging Violence: Realism, Romanticism, and Reinforcing Gender Disruptions .....186

Implications for Further Research

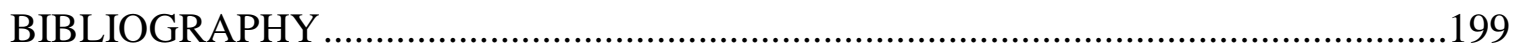

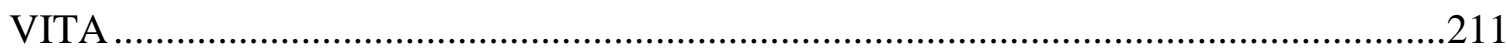




\begin{abstract}
One of the most popular manifestations of spectacle in the theatre is violence. Frequently, violence on the stage manifests in the form of violence towards women at the hands of men. As a woman violence and intimacy designer, I wanted to find works that challenged and subverted this popular staging and question what those works have to say about gender, violence, and gender performance. Two playwrights who are challenging long-held dramatic representations of women and violence are playwrights Sheila Callaghan and Marisa Wegrzyn. Callaghan and Wegrzyn are two of the founders of the Kilroys, a group of femme-identifying literary managers, playwrights and producers living in Los Angeles, California, who organized in 2013 to promote the work of female and trans playwrights. Not only do their most representative works contain several acts of violence committed by women characters, but the nature of these portrayals of violence strays from "traditional" representations of violence. Using a range of relevant theoretical lenses, I will analyze four representative plays_-Sheila Callaghan's Roadkill Confidential and That Pretty Pretty; or, the Rape Play and Marisa Wegrzyn's The Butcher of Baraboo and Killing Women to investigate how these works disrupt essentialist notions of gender and identity, with special attention to the implications and meanings of their dramatic representation of onstage acts of violence committed by women. Through critical analysis of these works, this dissertation seeks to increase understanding of how these performances of violence challenge heteronormative notions of gender. As the context in which these violent acts occur is crucial, this dissertation analyzes the gendered implications of the setting, plot, and characterizations of each work. Additionally, this dissertation explores how designing the violence within these moments may help reinforce the gender disruption created by Callaghan and Wegrzyn.
\end{abstract}




\section{CHAPTER ONE}

\section{Introduction}

"Kate, you throw a great punch, but you need to learn how to receive one better because women are always on the receiving end in theatre."

This was said to me as an undergraduate student by a female fight instructor in my very first stage combat class. This moment, while intended to be a fleeting moment of guidance from my instructor, has become cemented in my brain. In the moment, I was puzzled, but took the note seriously and headed back to my apartment. On the walk home, I began to interrogate this statement in more detail. What about all the images of strong women I saw on television growing up, like teenage secret agent Kim Possible, the yellow and pink Power Rangers, and The Powerpuff Girls? If I never get to throw a punch, then why is a female fight instructor teaching me how to do one? I was confused about my potential prospects in acting with stage combat. If I am good at throwing a punch, why are there not opportunities for me to showcase my talent?

Unsatisfied with the answers I could come up with to these questions, I decided to start seeking out and collecting plays in which women committed acts of violence onstage. That quest has translated into several years of building a library of texts that provided me, or any of my woman-identifying students, with opportunities to perform onstage violence.

Tracing the texts I had through theatre history, visibility of violent female characters grows over time. ${ }^{1}$ Starting with the Greeks, Medea and Clytemnestra have

\footnotetext{
${ }^{1}$ These works are referenced as highlights or iconic milestones in violent female characters through theatre history and are intended to be representative of the types of violence the audience does or does not see, rather than being a comprehensive survey of all such instances.
} 
cemented themselves in the canon of violent women in theatre, but their violent acts are committed offstage. During the medieval period, entertainment was often divided into two camps - liturgical and secular. Liturgical drama would rarely stage the violent acts that occur within the bible (for example, the crucifixion), and secular drama and pageant wagons would generally use effigies in place of actors to stage acts of violence. ${ }^{2}$ The dramas of the Spanish Golden Age and the Italian Renaissance feature more women performing violence on stage. Columbina, one of the zanni characters of Commedia Dell'Arte, would sometimes use a slapstick or her tambourine to beat sense into other characters. ${ }^{3}$ Meanwhile, women characters from Spain's Golden Age like Rosaura in Pedro Calderon de la Barca's Life is a Dream, were occasionally given opportunities to fight against opponents onstage. Restoration comedy in Great Britain depicted a considerable amount of attempted violence committed by women, whether they were in breeches roles or presenting as feminine characters. A key example of this is Aphra Behn's The Rover, in which the sex worker Angelica threatens the main character Willmore by pressing a gun against his chest repeatedly until Don Antonio, another potential suitor, disarms her. ${ }^{4}$ Restoration comedy also brought forth the refined art of dueling with smallsword - a delicate weapon that even women could maneuver with ease. Over the course of the 1800s, the trend of dramatizing acts of violence by women spreads throughout Europe and explodes with the emergence of realism and naturalism. ${ }^{5}$ George Bernard Shaw's Pygmalion contains one of the most iconic moments of female

\footnotetext{
${ }^{2}$ Oscar G. Brockett and Franklin J. Hildy, "European Theatre in the Middle Ages," in History of Theatre, 9th ed. (Boston: Allyn and Bacon, 2003), 93.

${ }^{3}$ Tim Shane, "Commedia Stock Characters Columbina," accessed October 14, 2018, http://www.timshane.com/Commedia-Columbina.htm.

${ }^{4}$ Aphra Behn, "The Rover; or, the Banish'd Cavaliers.," Project Gutenberg, accessed November 7, 2018, https://www.gutenberg.org/files/21339/21339-h/files/rover.html.

5 This information is drawn from a general survey of English works from the restoration era to the present.
} 
violence onstage during the Edwardian era. ${ }^{6}$ Eliza Doolittle, enraged at Henry Higgins for using her and claiming her victorious deception as his own, throws his slippers at him when he enters the parlor to look for them. ${ }^{7}$ The trend of British works using onstage female violence for comedy continues into the 1930s with British farce Private Lives by Noel Coward, in which Amanda breaks a record over the head of her ex-husband Elyot and he retaliates by slapping her in the face. ${ }^{8}$ Throughout the modern era the frequency of women performing violence onstage climbs, most predominantly after the 1960 s. Some representative texts containing women performing onstage violence include The Rimers of Eldritch by Lanford Wilson, Fool for Love by Sam Shepard, Cementville by Jane Martin, Marisol by Jose Rivera, The Beauty Queen of Leenane by Martin McDonagh, The Glory of Living by Rebecca Gilman, and Breath, Boom by Kia Corthron.

A general understanding of human history offers an obvious explanation for the dearth of female characters performing acts of violence onstage, as women in real life were accorded fewer opportunities to engage in violent acts. Acts of physical aggression and violence, including war and murder as well as acts of general physical abuse, have been the domain of men. When Shakespeare's Lady Macbeth sets out to murder the king, she exhorts the gods to "unsex me here!"9 In other words, Lady M cannot commit this violent act as a woman. She needs a gender re-assignment before carrying out the bloody deed.

${ }^{6}$ George Bernard Shaw, "Pygmalion," Project Gutenberg, accessed November 7, 2018, https://www.gutenberg.org/files/3825/3825-h/3825-h.htm\#act4.

\footnotetext{
${ }^{8}$ Noel Coward, Private Lives: An Intimate Comedy in Three Acts (New York: Samuel French, 1947).

${ }^{9}$ William Shakespeare, "The Tragedy of Macbeth," accessed May 3, 2019, http://shakespeare.mit.edu/macbeth/full.html.
} 
When women do commit acts of violence, in the dramatic texts I surveyed, the acts tended to be reactive, retaliatory, or self-harming. Although these acts would indeed provide the opportunities I sought to develop and practice a creative, physical artform, I found these revelations oddly troubling. It seemed that the representations held two diametrically opposed viewpoints; either women are victims that are in need of rescue, or the only way that women could enact some form of power on their environment is to "lash out" and inflict violence on themselves or others. These works were reinforcing the stereotype that women are innately passive and re-active and that they can only exert will and enact violence when there is a "socially valid" reason, such as escaping a domestic violence scenario or killing themselves to escape their troubles, problems, and mistakes. To add to the complexity, the images I saw growing up of the power rangers and Powerpuff Girls showed young women and girls asserting a sense of agency through mutual combatancy — both parties agreed to the conflict and the fight, and whomever was the strongest, smartest, or luckiest in the end would be declared the victor (most often the heroines). What had begun as a question about limited artistic opportunities was morphing into larger questions about gender identity. What was the relationship between violence and gender? Why was it that in some instances, I was troubled by women enacting violence, whereas in others, I found redemption and empowerment? What does it mean when women commit acts of violence? Why were these empowered, (often) superheroine figures solely relegated to the world of film and television, and yet had so little representation in the theatrical world? Why are women in western culture "always" on the receiving end of violence? Why does a strong "warrior woman" have to be the exception to this alleged rule? What is "appropriate" or "normal" behavior for a woman 
to perform? Upon further reflection, I realized that my interest in these questions went far beyond my need for opportunities to practice a particular theatrical artform. I would find myself cheering on female characters that were aggressive or violent as a tangential source of empowerment. Although I was not entirely sure why I was cheering the act of harming, possibly killing, another human being, I knew these acts had deeper meaningsthat somehow these fictional acts represented a wider range of possibilities for me both as an artist and as a woman. At its core, the relationship I became most interested in, as a woman and a feminist, is the relationship between gender and violence, and as a theatre artist, I wanted to explore this relationship through analysis of dramatic works with violent female characters in them.

I began to interrogate dramatized representations of violent acts by women in my Masters' thesis (completed in 2015). ${ }^{10}$ In it, I examined four plays containing acts of violence committed by women. Wanting to elevate the works of women playwrights of color, I selected three works from playwrights of different ethnicities (Suzan-Lori Parks' In the Blood, Young Jean Lee's Songs of the Dragons Flying to Heaven, and Maria Irene Fornes' The Conduct of Life), and one, Tracy Letts' August: Osage County as a White male-authored work for comparison. The purpose of this thesis was to interrogate the specific acts of onstage violence committed by female characters; I wanted to examine who was enacting the violence, who or what was the target of the violence, and what that might say about the character enacting the violence. After analyzing these works, I concluded that the utilization of violence by Parks, Lee, and Fornes is didactic in nature and is used as a tool to force the audience to reflect upon the violence as an expression of

\footnotetext{
${ }^{10}$ Kate Busselle, "When Oppressed Women Attack: Female-Enacted Violence through Minority American Female Playwrights' Works" (Thesis, University of Central Florida, 2015).
} 
societal pressure (such as poverty in In the Blood and intimate partner violence in The Conduct of Life). Letts, by comparison, mainly uses violence as a moment of levity and directs the violence towards objects more than other characters, which may reduce the impact that these moments of violence have on the audience. ${ }^{11}$ All the acts of violence depicted in these plays were, like those discussed earlier, reactive, self-harming, or retaliatory. While important in the development of my work as a scholar, at the conclusion of this thesis I realized that the investigation left many questions unanswered. It left me especially curious about work by women featuring female characters who are actively aggressive, not employing violence that fell into one of those "traditional" categories that seemed to reinforce essentialist attitudes about women. I began to search for additional plays that featured aggressive women, and I found them in more contemporary works written sometime after 2001. I also wanted to find playwrights who included more than one instance of aggressive women across their plays as it would be more indicative of a trend than a sampling of works from four different playwrights with different cultural backgrounds and identities. My continuing research has revealed several contemporary playwrights who are beginning to incorporate violent and aggressive acts by women into their works. I am particularly interested in how women playwrights craft these aggressive women characters and the varying presentations of gender these characters perform, so my focus began to narrow to contemporary women playwrights. These playwrights include Rebecca Gilman, Cherrie Moraga, Naomi Wallace, Hannah Moscovitch, Naomi Iizuka, and Sarah Kane, to name a few. These

\footnotetext{
${ }^{11}$ Ibid.
} 
playwrights are known for frequently addressing and critiquing essentialist and heteronormative notions of cultural identities.

Among these writers who are challenging long-held dramatic representations of women and violence, two relatively unknown innovators have emerged as particularly worthy of attention. They are playwrights Sheila Callaghan and Marisa Wegrzyn, two of the founders of the Kilroys, a group of femme-identifying literary managers, playwrights and producers living in Los Angeles, California, who organized in 2013 to promote the work of female and trans playwrights. With a name intended to conjure the World War II graffiti tag "Kilroy was Here," 12 the goals of The Kilroys are similar to those of World War II soldiers: to playfully, and purposefully, make their presence known - in this case, in the theatre world. The Kilroys are committed to ending both the systemic underrepresentation of female and trans playwrights in the American theater and the underrepresentation and misrepresentation of female and trans characters. They are especially concerned with producing works that challenge gender /sexual stereotypical and negative portrayals of women as submissive, weak, and inferior to men, and reliant upon men to further their own narratives. In this context, women characters displaying aggressive, even violent, tendencies may be viewed as especially subversive. Callaghan and Wegrzyn are beginning to garner considerable critical attention, winning several awards (Wegrzyn received the Wasserstein Prize in 2009, and Callahan has received The Princess Grace Award for emerging artists, the Susan Smith Blackburn Award, and the Whiting Award to name a few). Their works are being read, studied, and produced, and are often featured on The Kilroys' annual lists highlighting the best work of female and

\footnotetext{
12 “About," The Kilroys, last modified June 11, 2015, accessed January 4, 2019, https://thekilroys.org/about/.
} 
transgender playwrights. While Callaghan and Wegrzyn are not the only contemporary dramatists who are writing women who commit acts of violence, two works by Wegrzyn (Killing Women and The Butcher of Baraboo) and two by Callaghan (Roadkill Confidential and That Pretty Pretty; or, The Rape Play) are notable both for the extent (the frequency of examples of the phenomenon occurring onstage in front of the audience) and the extraordinary nature of the representations that veer from the traditional reactive violence traditionally enacted by women onstage. All four works contain particularly provocative and diverse portrayals of gender identit(ies) and gendered violence and all four are notably original and innovative in form. These four representative works are the focus of this study. Callaghan's Roadkill Confidential, premiering at Clubbed Thumb in New York in 2010, examines the life of Trevor, a woman who hits rabbits and other small animals with her car and tortures them to create an art installation. That Pretty Pretty; or, The Rape Play by Callaghan presents explosive stereotypical tropes in drafts of a burgeoning (male) screenwriter's screenplay; it debuted at Rattlestick Playwrights Theatre in New York in 2009. Wegrzyn's Killing Women, first produced at Washington University in Saint Louis, Missouri in 2002, evokes a Kill Bill meets 9 to 5 vibe, observing the lives of professional hitwomen. Wegrzyn's The Butcher of Baraboo, which debuted in 2007 at Second Stage Theatre Uptown, New York, presents a Midwestern twist on family secrets in a conservative town. These plays, debuting within an eight-year period from 2002-2010, contain onstage acts of violence committed by aggressive women, and these acts of violence are often associated with these characters' careers.

\section{PURPOSE}


Through critical analysis of these representative works, this dissertation seeks to extend burgeoning inquiry into works by women in the United States who write plays containing onstage acts of violence by aggressive women. More specifically, this dissertation seeks to increase understanding of how these performances of violence challenge heteronormative notions of gender by analyzing these aggressive and violent actions in the four representative plays named above. As the context in which these violent acts occur is crucial, this dissertation will also analyze the gendered implications of the setting, plot, and characterizations of each work. Additionally, this dissertation will explore how designing the violence within these moments may help reinforce the gender disruption inherent in the scene.

\section{JUSTIFICATION}

Violence is intriguing. It is universally condemned yet to be found everywhere. Most of us are both fascinated and horrified by it. It is a fundamental ingredient in how we entertain ourselves (children's stories, world literature, the movie industry) and an essential feature of many of our social institutions. In most parts of the world it is notoriously common in family life, religious affairs, and political history. ${ }^{13}$

As Robert F. Litke, Professor of Philosophy at Wilfred Laurier University notes above, violence is a part of culture as well as cultural entertainment, in spite of its universal condemnation. American culture is known for being especially violent, for frequent mass shootings and easy access to firearms. According to Amnesty International, among highincome countries, eighty percent of all gun deaths occur in the United States. ${ }^{14}$

Everytown for Gun Safety Action Fund has reported that each day, ninety-six Americans

\footnotetext{
${ }^{13}$ Robert F. Litke, "Violence and Power," in Violence: A Philosophical Anthology, ed. Vittorio Bufacchi (New York: Palgrave Macmillan, 2009), 296.

14 "Gun Violence," Amnesty International USA, accessed November 10, 2018, https://www.amnestyusa.org/issues/gun-violence/.
} 
are killed due to gun violence and that Americans are twenty five times more likely to be murdered with a gun than those in other developed countries. ${ }^{15}$ The easy access to firearms in the United States is due to the second amendment to the United States constitution, which states that all United States citizens have a right "to keep and bear Arms," and justifies this as necessary for "the security of a free State."16 The ease of access to firearms in the United States could be a major factor of the frequency and lethality of mass shootings in the United States. Since 1982, one hundred and six mass shootings have occurred in the United States, and sixty-seven of them have occurred since $2006 .^{17}$

\section{Gender and Violence}

All but one of the mass murderers identified in the above report were men and were often lone gunmen showing signs of compromised mental health. ${ }^{18}$ Moreover, men are more likely to be the perpetrators of violence of any kind, and women represent only seven percent of the incarcerated population in the United States. ${ }^{19}$

Because so many instances of violence, especially high-profile incidents of gun violence in the United States, are committed by men, one could see how it would be easy to make the corollary leap to say that men must be more violent than women "by nature." Some evolutionary psychologists support what is called the "male warrior hypothesis," which contends that men are more aggressive than women due to the evolutionary

\footnotetext{
15 "Everytown for Gun Safety," Everytown for Gun Safety, accessed November 10, 2018, https://everytown.org/learn/.

16 "Second Amendment | Wex Legal Dictionary / Encyclopedia | LII / Legal Information Institute," accessed November 10, 2018, https://www.law.cornell.edu/wex/second_amendment.

${ }^{17}$ Deanna Pan, "A Guide to Mass Shootings in America," Mother Jones, n.d., accessed November 10, 2018, https://www.motherjones.com/politics/2012/07/mass-shootings-map/.

${ }^{18}$ Ibid.

${ }^{19}$ Renee Sorrentino, Susan Hatters Friedman, and Ryan Hall, "Gender Considerations in Violence,"

Psychiatric Clinics of North America 39, no. 4 (December 2016): 701.
} 
tendency for men to protect their own tribes over thousands of years of evolution, and those who were successful at their aggression are more likely to have survived. ${ }^{20}$ Many contemporary scientists (biologists, psychologists, and geneticists alike) tend to blame testosterone, the primary sex hormone for men, for violent and aggressive behavior. Joe Herbert, an emeritus professor of neuroscience at the University of Cambridge, points to castration and neutering as evidence for testosterone being inherently linked to aggression: "Comparative and experimental studies show that interfering with the early actions of testosterone on the brain, or castration in adulthood, reduces aggressive tendencies, as any owner of a 'neutered' dog or cat will know." ${ }^{21}$ Herbert also argues that the hormone "inclines males to like violence and use it as a strategy," and that testosterone is also responsible for risk-taking behavior exhibited by men. ${ }^{22}$ Menelaos L. Batrinos of Athens University Medical School conducted a survey of all of the published studies regarding male aggression and testosterone and found that while there did seem to be a higher testosterone level in male prisoners and male athletes after competing in sporting events, "Most of the studies, however, were conducted by self-reported questionnaires, the accuracy of which is questionable." 23

However, it seems that female scientists are challenging this notion of testosterone as the primary cause of violence. Debra Niehoff, author of The Biology of

\footnotetext{
${ }^{20}$ M. M. McDonald, C. D. Navarrete, and M. Van Vugt, "Evolution and the Psychology of Intergroup Conflict: The Male Warrior Hypothesis," Philosophical Transactions of the Royal Society B: Biological Sciences 367, no. 1589 (March 5, 2012): 670-679.

${ }^{21}$ Joe Herbert, "Without Testosterone, Would There Be War?," Psychology Today, accessed November 10, 2018, https://www.psychologytoday.com/blog/hormones-and-the-brain/201603/without-testosteronewould-there-be-war.

${ }^{22}$ Ibid.

${ }^{23}$ Menelaos L. Batrinos, "Testosterone and Aggressive Behavior in Man," International Journal of Endocrinology \& Metabolism 10, no. 3 (June 1, 2012): 567.
} 
Violence: How Understanding the Brain, Behavior, and Environment can Break the

Vicious Circle of Aggression, argues:

The focus on testosterone, sexual predators, and male homicide rates has reinforced the idea that violence is a masculine prerogative. Men are aggressors. Women, on the other hand, are peacemakers - unless they are targets. Women are raped, beaten, or attacked by someone they know seven times more frequently than men...Trauma perpetuates fear. The most extreme example of social defeat, it also profoundly alters the likelihood of future aggression by resetting chemical parameters to favor defensive, rather than offensive, behavior. Once injured, the fear of retaliation constrains women's aggression....Men-bigger, heavier, and quicker to pick up a gun-fight back. Women, all too conscious of their vulnerability, often have few options but to freeze. ${ }^{24}$

Rather than argue that the lack of testosterone is the root cause of women being less inclined to use violence than men, Niehoff suggests that once women have become exposed to violence, their chemical reaction is altered to be more likely to react defensively than offensively. Niehoff continues,

The violence of men and the violence of women differs in form, substance, and chemistry. But it is the result of the same biological process. Regardless of sex or age, behavior is not simply driven by a single hormone or by one neurotransmitter, but evolves out of the interlocking relationship that links perception, interpretation, and response, the circle that joins the brain and the surrounding world. ${ }^{25}$

Instead of focusing on the Cartesian split model of nature vs. nurture, estrogen vs. testosterone, Niehoff is advocating for a more comprehensive approach for the analysis of violent behavior, as no one thing can be the root cause of it. Similarly, Bandy X. Lee, a psychiatrist at Yale School of Medicine, states:

The underlying assumption is that we can 'explain' phenomena by reducing behavior to biology, biology to physics, and physics to the movements of elementary particles. We now know that this premise is flawed: not only are

\footnotetext{
${ }^{24}$ Debra Niehoff, The Biology of Violence: How Understanding the Brain, Behavior, and Environment Can Break the Vicious Circle of Aggression (New York: The Free Press, 1999), 167.

${ }^{25}$ Ibid., 171.
} 
elementary particles impossible to find, even if they were, they seem to increase in complexity rather than decrease. ${ }^{26}$

Lee and Niehoff both argue for more holistic, cross-disciplinary approaches to analyzing and understanding violent human behavior. Reductionism to one gene, hormone, or sex as the culprit of violent behavior is being significantly challenged, yet the assumption that men are inherently more violent remains. While men do commit acts of violence three times as often as women, the fact that they are biologically hardwired to do so is questionable. How does this myth continue to be overstated?

It seems that second-wave feminism may be partially to blame for perpetuating that myth. Violence is part of the reality of the world we live in, yet feminist scholarship, especially second-wave-influenced feminist scholarship, tended to embrace the essentialist argument that men are inherently disposed to violence, and women are inherently peacemakers, possibly in support of previous feminist work that has critiqued violence (both domestic and military), as violence in and of itself has been deemed by some feminist scholars as anti-feminist, and domestic violence and sexual violence as especially egregious examples of patriarchal oppression of women. Andrea Dworkin, one of the most controversial figures of second-wave feminism, addressed this issue in her speech to the NOW Conference on Sexuality in 1974:

The male sexual model is based on a polarization of humankind into man/woman, master/slave, aggressor/victim, active/passive. This male sexual model is now many thousands of years old. The very identity of men, their civil and economics power, the forms of government that they have developed, the wars they wage, are tied irrevocably together. All forms of dominance and submission, whether it be man over woman, white over black, boss over worker, rich over poor, are tied irrevocably to the sexual identities of men - and are derived from the male sexual model...There is no freedom or justice or even common sense, in developing a male sexual sensibility--a sexual sensibility that is aggressive, competitive,

\footnotetext{
${ }^{26}$ Bandy X. Lee, "Causes and Cures II: The Biology of Violence," Aggression and Violent Behavior 25
} (November 1, 2015): 205. 
objectifying, quantity oriented. There is only equality. To believe that freedom or justice for women, or for any individual woman, can be found in mimicry of male sexuality is to delude oneself and to continue the oppression of one's sisters...I want to ask you to make a different commitment - a commitment to the abolition of poverty, rape and murder; that is, a commitment to ending the system of oppression called patriarchy; to ending the male sexual model itself. ${ }^{27}$

In this excerpt, Dworkin argues that all forms of dominance are "irrevocably" tied to men and to the male sexual model. In addition, she asserts that women who attempt to mimic the behavior of men are oppressing other women in doing so. According to Dworkin, the only way to resolve the issue of masculine aggression is to end the male sexual model and all sex and gender roles that go with it.

This ideology is being contested in contemporary feminism, most notably in Jamie R. Abrams" “The Feminist Case for Acknowledging Women's Acts of Violence” published in $2016 .^{28}$ In it, Abrams makes the case that feminist movements have practiced a "strategy of containment" to make progressive steps forward in women's rights in the United States, specifically when it comes to violence:

When deploying this strategy, domestic violence advocates respond to women's acts of domestic violence by accepting male victims within its existing infrastructure, monitoring vigilantly for statistical exaggerations, and preserving the dominant framing of domestic violence as a gendered issue. This strategy thus positions women's acts of violence as a footnote to the larger story of women as victims of male violence. $^{29}$

By employing the "strategy of containment," the feminist movement has largely dismissed the possibility of female aggressive behavior, even while simultaneously advocating for male victims of domestic violence. Abrams argues that it would be to the

\footnotetext{
${ }^{27}$ Andrea Dworkin, "Renouncing Sexual 'Equality,"” off our backs: a women's newsjournal 4, no. 11 (1974): 2.

${ }^{28}$ Jamie R Abrams, “The Feminist Case for Acknowledging Women's Acts of Violence," Yale Journal of Law and Feminism 27, no. 2 (2016): 45.

${ }^{29}$ Ibid., 289.
} 
benefit of the movement to move beyond the strategy of containment because "Moving beyond a strategy of containment stands to diffuse some of the most entrenched of stereotypes that plague understandings of domestic violence and may even reinforce it."30 Carrington's "Girls and Violence: The Case for a Feminist Theory of Female Violence" also supports this view and advocates for the development of a feminist theory of female violence as an act of resistance to the essentialist explanations of violence committed by women, such as women and girls "acting like boys." 31 Finding it troubling that this gap in the feminist and criminological literature had yet to be addressed, Carrington puts forward this call to action to encourage feminist scholars to engage with and attempt to increase understanding of acts of violence committed by women as an act of resistance to previous, essentialist explanations that serve to sustain and reinforce anti-feminist sex/gender hierarchies. Carrington continues:

Female violence challenges deeply ingrained assumptions held by feminists, lawyers, criminologists, media commentators, parents and policy makers. Criminological theory has a long history of essentialising violence as a capacity associated primarily with boys, overlooking the capacity for the female sex to participate in and inflict violence. So it is hardly surprising that feminist criminologists too have overlooked female violent offenders assuming women are mostly victims and not perpetrators of violence. ${ }^{32}$

Contemporary feminists seem to be moving away from the essentialist standpoint of their predecessors and shifting the focus to ending all forms of violence. As bell hooks, one of the most notable contemporary feminists, stated in her text Feminism is for Everybody:

"Women and men must oppose the use of violence as a means of social control in all its manifestations: war, male violence against women, adult violence against children,

\footnotetext{
${ }^{30}$ Ibid., 304.

${ }^{31}$ Kerry Carrington, "Girls and Violence: The Case for a Feminist Theory of Female Violence," International Journal for Crime, Justice, and Social Democracy 2, no. 2 (2013): 73.

${ }^{32}$ Ibid., 71-72.
} 
teenage violence, racial violence, etc. Feminist efforts to end male violence against women must be expanded into a movement to end all forms of violence." 33 I agree with hooks' sentiment that all violence should come to an end, and I certainly do not advocate for nor celebrate violence enacted by anyone. However, hooks and other likeminded feminists may be missing the underlying implications of 'buying into' the dominant, essentialist narrative related to violence and gender. The literature overwhelmingly categorizes violence (and its correlative attributes such as aggression, power, and willfulness) as male and passivity (and its correlatives weakness, vulnerability, indecision) as female, a critical blind spot in the development of feminism as a whole. This blind spot in feminist analysis, scholarship, and research may be preventing a deeper understanding of violence and gender, along with the relationship between the two.

According to the FBI's Uniform Crime Reporting (UCR) program, "violent crime is composed of four offenses: murder and nonnegligent manslaughter, rape, robbery, and aggravated assault. Violent crimes are defined in the UCR Program as those offenses that involve force or threat of force." 34 The FBI UCR also reported that "Seventy-three percent of the persons arrested in the nation during 2017 were males. They accounted for 79.5 percent of persons arrested for violent crime." 35 Conversely, this means that roughly 20.5 percent of violent crime arrests were of females. ${ }^{36}$ This data points to the fact that

\footnotetext{
${ }^{33}$ bell hooks, Feminism Is for Everybody: Passionate Politics (New York: Routledge, 2015), 66.

34 "Violent Crime," FBI 2017 Crime in the United States, accessed October 16, 2018, https://ucr.fbi.gov/crime-in-the-u.s/2017/crime-in-the-u.s.-2017/topic-pages/violent-crime. 35 "Persons Arrested," FBI 2017 Crime in the United States, accessed October 16, 2018, https://ucr.fbi.gov/crime-in-the-u.s/2017/crime-in-the-u.s.-2017/topic-pages/persons-arrested.

${ }^{36}$ The FBI UCR compiles crime data based on sex rather than gender, which is why the use of male and female is used here. The FBI UCR does not seem to account for variations in sex or gender identity in their data. For example, it may be possible that a trans woman may have been categorized as male due to having male genitalia. In addition, the FBI UCR has a footnote indicating that their data points are rounded, so several of the categories of male vs. female violence may not add to 100 percent.
} 
women in the United States are catching up to men in terms of violence and aggression. According to criminologist Kerry Carrington, assaults committed by girls under the age of 18 increased $18 \%$ between 2002-2009, whereas assaults committed by boys under the age of 18 only increased $0.2 \% .{ }^{37}$ It is unclear what is causing a jump in female offenders (possible explanations vary from shifting modes of governing and policing, celebrating violent femme culture, and utilizing the internet to engage in verbal abuse and cyberbullying $^{38}$ ), but a jump is clearly noticeable for this time period. While one could hardly expect feminists, or anyone else, to celebrate an increase in female criminality, the implications for the dismantling of an essentialist gender ideology that has unquestionably worked to oppress women, should not be ignored. Of all the gendered attributes and behaviors common to western culture, the masculinization of violence and aggression may be the most difficult to dislodge. Women are mothers, givers of life-a woman who commits acts of brutality is indeed a difficult reality to accept. Given this context, the choice by third wave feminist playwrights like Callaghan and Wegrzyn to choose violence as a dramaturgical device through which to challenge ideas about gender seems particularly apt.

Given that there is a strong case to examine the relationship between violence and gender, it is also important for us to examine the relationship between violence, gender, and theatre. As theatre is often touted as the "mirror" to society and vice versa, many feminist scholars have attempted to revisit, reconsider, and revise works of theatre through feminist and anti-essentialist lenses. Some of the forerunners of this work include feminist theatre scholars like Sue-Ellen Case, Gayle Austin, and Jill Dolan. All three of

\footnotetext{
${ }^{37}$ Carrington, "Girls and Violence: The Case for a Feminist Theory of Female Violence." 38 Ibid, 66.
} 
these scholars have produced texts with the aim of challenging the way theatre is produced, consumed, and analyzed. Similar to Andrea Dworkin's divisional hierarchy, Dolan argues that performance has fallen under a similar paradigm. In her text The Feminist Spectator as Critic, Dolan states:

$[\mathrm{M}]$ ost performance employs culturally determined gender codes that reinforce cultural conditioning. Performance usually addresses the male spectator as an active subject, and encourages him to identify with the male hero in the narrative. The same representations tend to objectify women performers and female spectators as passive, invisible, unspoken subjects. The feminist spectator viewing such a representation is necessarily in the outsider's critical position. She cannot find a comfortable way into the representation, since she finds herself, as a woman (and even more so, as a member of the working class, a lesbian, or a woman of color), excluded from its address. ${ }^{39}$

Often, theatre spectators are forced to observe a play containing a male hero, whereas the role of the woman is to be a "passive, invisible, unspoken" subject that is a conduit for the hero's journey. Feminist spectators have difficulty identifying with these narratives as women have oppressive power structures to navigate that male protagonists may never face. Both Dolan and Austin are proponents of "resistant" readings of works that champion a male hero or are written from a male perspective. As Austin states in her work Feminist Theories for Dramatic Criticism,

By using the strategy of resisting, feminist critics can point out the ways the text inscribes masculinity, help change the process of reading for women, and suggest ways that performances of the text can resist its own immasculation of the audience. The process of intervention in production can be very effective in increasing audience awareness of what it is watching, hearing and feeling. ${ }^{40}$

This strategy of resistant reading applied to works containing women acting aggressively or enacting violence raises questions regarding the intermingling of gender, violence, and

\footnotetext{
${ }^{39}$ Jill Dolan, The Feminist Spectator as Critic, 2nd ed. (Ann Arbor: University of Michigan Press, 1988), 2.

${ }^{40}$ Gayle Austin, "Feminist Literary Criticism: The 'Resisting Reader," in Feminist Theories for Dramatic

Criticism (Ann Arbor: University of Michigan Press, 1990), 29.
} 
theatre. Why are some forms of gender violence staged more often than others (for example, the prevalence of men inflicting violence on women, but the rarity of women committing violence at all)? What do these performances say about gender roles in relation to violence and entertainment? What visual representations of violence are deemed justifiable, horrific, or comic, and does gender play a role in those distinctions? What meanings may there be in onstage performances of violence by women characters written by women playwrights?

These questions collide when examining the works of Sheila Callaghan and Marisa Wegrzyn. Their works have received little scholarly attention, yet their works contain a plethora of violent acts. Not only do these works contain several acts of violence committed by women characters, but the nature of these portrayals of violence stray from "traditional” representations of violence; for example, Callaghan's character who creates art with rabbits she hit with her car, and Wegrzyn's characters who are career hitwomen.

These fictional representations contribute to urgent, ongoing debates in today's culture regarding domestic and sexual violence and shifting gender roles. Even as sociologists, biologists, psychologists, and criminologists attempt to understand violence in real life, theatre and performance scholarship may also contribute to understanding. As art serves to both reflect and shape culture, examining these acts in theatrical representations can shed light on real life experiences. This work will also be of use to theatre artists such as dramaturgs, actors, and directors seeking deeper understanding of these texts and potential implications for staging acts of violence committed by women onstage. 
Sheila Callaghan has received several awards, grants, and fellowships over the course of her career, including the Susan Smith Blackburn Award, and the Whiting Award in Drama, the Princess Grace Fellowship for Playwriting, a Jerome Fellowship from the Playwright's Center in Minneapolis, a MacDowell Colony Residency, and a Cherry Lane Theatre Mentorship Fellowship. ${ }^{41}$ Callaghan has also been nominated for a Golden Globe Award for her work on the Hulu series Casual as well as a Writers' Guild of America Award for Episodic Drama for her work on the television series Shameless. ${ }^{42}$ She has written fifteen plays thus far, and many of them are published through Playscripts or Samuel French. Her work That Pretty Pretty; or The Rape Play has already garnered scholarly attention and has been deemed a text worthy of further inquiry;

Roadkill Confidential has yet to be explored in scholarship. Callaghan's works are structurally experimental, whereas Wegrzyn's plays adhere more to a traditional play structure. While Callaghan's works have fewer instances of violence in comparison to Wegrzyn's, Callaghan's works are more widely produced.

Marisa Wegrzyn splashed onto the theatre scene when she won the 2009 Wendy Wasserstein Prize for her play Hickorydickory at the age of $28 .{ }^{43}$ Her works have been produced Off-Broadway and at Steppenwolf Theatre in Chicago. ${ }^{44}$ She is also a resident playwright with Chicago Dramatists and one of the founders of Theatre Seven Chicago. ${ }^{45}$ Recently, she has been working in Los Angeles and has been screenwriting and

\footnotetext{
41 “Bio," Sheila Callaghan., August 28, 2018, accessed September 17, 2018, https://www.sheilacallaghan.com/bio/.

42 Ibid.

${ }^{43}$ Felicia R. Lee, "Wasserstein Prize Goes to Playwright, 28," The New York Times, December 1, 2009, sec. Theater, accessed September 17, 2018, https://www.nytimes.com/2009/12/02/theater/02artsWASSERSTEINP_BRF.html. 44 "Marisa Wegrzyn | Playscripts, Inc.," accessed September 17, 2018, https://www.playscripts.com/playwrights/bios/867.

45 Ibid.
} 
producing for the hit series Goliath and The Mentalist. ${ }^{46}$ At this point in time, there is no scholarship on the works of Marisa Wegrzyn. This is likely due to her more recent development as a playwright and the fact that only four of her plays have been published. She also seems to have taken a hiatus from playwriting after the creation of The Kilroys with Callaghan and some screenwriting, primarily for the series The Mentalist and Goliath ${ }^{47}$ Her work has been anthologized several times over in contemporary play and monologue anthologies. ${ }^{48}$ Although they have thus far received no attention, Wegrzyn's plays The Butcher of Baraboo and Killing Women are most fruitful for the purposes of this study as these plays have numerous instances of women committing violence. It would be an egregious oversight to ignore these works when examining representations of violent and aggressive women. This study is the first scholarly examination of Wegrzyn's works.

\section{METHODOLOGY}

The method of this study is critical, textual analysis. Using a range of relevant theoretical lenses, I will analyze four representative plays_-Sheila Callaghan's Roadkill Confidential and That Pretty Pretty; or, the Rape Play and Marisa Wegrzyn's The Butcher of Baraboo and Killing Women to investigate how these works disrupt essentialist notions of gender and identity, with special attention to the implications and

\footnotetext{
46 "Marisa Wegrzyn," IMDb, accessed September 17, 2018, http://www.imdb.com/name/nm5794137/.

${ }^{47}$ It is difficult to know for certain what Wegrzyn is doing as she has no website. Her blog, Chainsaw Calligraphy, has not been updated since 2011, and the only form of digital contact Wegrzyn seems to have with the public is through her twitter account, @ howdymarisa, which she posts to approximately once per week.

${ }^{48}$ Lawrence Harbison, 2014: The Best Women's Stage Monologues, 2014; Lawrence Harbison, The Best Women's Stage Monologues of 2008 (Hanover, NH: Smith \& Kraus, 2009); Lawrence Harbison, New Playwrights: The Best Plays of 2008 (Hanover, N.H.: Smith and Kraus, 2008); Lawrence Harbison, The Best Men's Stage Monologues. 2017, 2017; Lawrence Harbison, The Best Women's Stage Monologues. 2017, 2017.
} 
meanings of their dramatic representation of onstage acts of violence committed by women. Questions guiding my research include:

- How are women and women's aggressive and violent acts portrayed in these works and how do those portrayals relate to prevailing notions about gender and sexual identity in the United States?

- How do these acts challenge essentialist notions of womanhood and manhood?

- How do the dramaturgical choices of the playwrights (including plot, setting, context, characterizations, and character relationships) impact the disruption of the gender performances of the characters, and how do these choices impact the interpretation and analysis of the violent acts?

- How do these works relate to each other in terms of their representation of gender and sexual identity?

- How might the staging of these acts of violence help or hinder the intention and impact of gender disruptions?

My readings will primarily focus on dramaturgical choices of the playwrights and on the specific acts of violence that characters enact against themselves and each other. These will include attempted acts of violence, threatened acts of violence, and completed acts of violence. Most often, these moments are described in the stage directions of the playwright's works. Broadly, I will treat each of the plays, characters, and individualized acts as specific performances of gender. As each of the acts vary in terms of the character performing the acts, the weaponry that may or may not be used, the given circumstances of the act (job-related, necessity, survival, etc.), and other variables that may impact the 
analysis of these acts, I will be using a wide-ranging framework of theory and analysis most relevant to each specific act and performance analyzed. To uncover these meanings, I will be employing semiotics to extrapolate meaning from the language and imagery around the violent acts. I will be utilizing intersectional identity theories relevant to this study, including feminist and other sociological theories to examine the living conditions and norms of these women in context. Representative works include "Hierarchies, Jobs, Bodies: A Theory of Gendered Organizations" by Joan Acker, Driven to Kill: Vehicles as Weapons by J. Peter Rothe, Powers of Horror: An Essay on Abjection by Julia Kristeva, and "POLICEwomen or PoliceWOMEN?: Doing Gender and Police Work" by Cara E. Rabe-Hemp. ${ }^{49}$ Other works of feminist theory useful for this examination include Judith Butler's Gender Trouble: Feminism and the Subversion of Identity, Butler's Bodies that Matter: On the Discursive Limits of 'Sex, 'Michael S. Kimmel's The Gender of Desire: Essays on Male Sexuality and Kirsten Smith's "Seduction and Sex: The Changing Allure of the Femme Fatale in Fact and Fiction." ${ }^{50}$ I will also include scientific and sociological data relating to gender, gender performance, and violence, such as Baris Cayli's "Performance matters more than masculinity: Violence, gender dynamics and mafia

\footnotetext{
${ }^{49}$ Joan Acker, "Hierarchies, Jobs, Bodies: A Theory of Gendered Organizations," Gender \& Society 4, no. 2 (June 1990): 139-158; J. Peter Rothe, Driven to Kill: Vehicles as Weapons (Alberta, Canada: The University of Alberta Press, 2008); Julia Kristeva, Powers of Horror: An Essay on Abjection, trans. Leon S. Roudiez (New York: Columbia University Press, 1982), accessed April 26, 2019, http://www.jstor.org/stable/3684782?origin=crossref; Cara E. Rabe-Hemp, "POLICEwomen or PoliceWOMEN?: Doing Gender and Police Work," Feminist Criminology 4, no. 2 (April 2009): 114-129. ${ }^{50}$ Judith Butler, Gender Trouble: Feminism and the Subversion of Identity, 2nd ed. (New York: Routledge, 1990); Judith Butler, Bodies That Matter: On the Discursive Limits of "Sex" (New York: Routledge, 1993); Michael S. Kimmel, The Gender of Desire: Essays on Male Sexuality (Albany, NY: State University of New York Press, 2005), http://proxy.mul.missouri.edu/login?url=http://search.ebscohost.com/login.aspx?direct=true\&db=nlebk\&A $\mathrm{N}=144997 \&$ site=eds-live\&scope=site; Kirsten Smith, "Seduction and Sex: The Changing Allure of the Femme Fatale in Fact and Fiction.," At the Interface / Probing the Boundaries, no. 90 (September 2017): $37-52$.
} 
women" and Sarah K. Murnen and Donn Byrne’s "Hyperfemininity: Measurement and Initial Validation of the Construct." 51

There have been some dissertations (discussed in the literature review) regarding the work of women playwrights writing violence as acts of resistance or empowerment. This study complements and extends this scholarship, and it is my intention to consider these findings in my analyses.

\section{Terminology and Definitions}

Violence can take many forms and is inflicted upon others in a variety of ways. World Bank economist and violence theorist Jamil Salmi, author of "The Different Categories of Violence," created a thorough typology of categorizing violence that includes direct violence, indirect violence, repressive violence, and alienating violence. ${ }^{52}$ Violence can be inflicted physically, emotionally, psychologically, or through deprivation of fundamental or higher rights. ${ }^{53}$ For the purposes of this dissertation, I am creating my own working definition based primarily on Salmi's first two categories of direct and indirect violence. I am defining an act of violence as one in which intentional physical contact is made or threatened by the aggressor towards the victim and in which pain is inflicted upon the victim due to that contact. This definition corresponds closely to the Oxford English Dictionary definition, which defines violence as, "The deliberate exercise of physical force against a person, property, etc.; physically violent behaviour or

\footnotetext{
${ }^{51}$ Baris Cayli, "Performance Matters More than Masculinity: Violence, Gender Dynamics and Mafia Women," Aggression and Violent Behavior 29 (2016): 36-42; Sarah K. Murnen and Donn Byrne, "Hyperfemininity: Measurement and Initial Validation of the Construct," Journal of Sex Research 28, no. 3 (August 1991): 479.

52 Jamil Salmi, "The Different Categories of Violence," in Violence: A Philosophical Anthology, ed. Vittorio Bufacchi (New York: Palgrave Macmillan, 2009), 311-319.

${ }^{53}$ Ibid., 317-318.
} 
treatment." ${ }^{54}$ Analyses of acts of violence will be confined to a number of specified moments in each text.

Both Callaghan and Wegrzyn identify all the characters in the dramatis personae of these plays in terms of the sex binary of male and female. All the characters identified as "female" use she/her/hers pronouns. In addition, one of the titles of the plays is Killing Women. From this data, and for the purposes of this dissertation, I am going to posit that these characters would most likely identify with the gender "woman."

\section{LITERATURE REVIEW}

\section{Dramatic Representations of Violence}

Recently, dramatic representation of violence has garnered some scholarly attention. In 2011 and 2012, two volumes of work regarding violence and drama were released: Violence in American Drama: Essays on Its Staging, Meanings and Effects, edited by Alfonso Ceballos Muñoz, Ramón Espejo Romero, and Bernardo Muñoz Martinez, and Performing Gender Violence: Plays by Contemporary American Women Dramatists, edited by Barbara Ozieblo \& Noelia Hernando-Real. Both volumes are excellent examples of critical literary analysis of violence; Violence in American Drama primarily exemplifies works in which the acts of violence women commit happen offstage, and Performing Gender Violence solely examines the works of women who write about violence against women. While violence occurring offstage is certainly standard practice in the theatrical world (it is often technically difficult and costly for theatres to stage acts of violence), I am interested in works in which the acts of violence occur in front of the audience. I believe there is intentionality behind staging violence in

\footnotetext{
54 "Violence, n.," OED Online (Oxford University Press, n.d.), accessed September 3, 2018, http://www.oed.com.proxy.mul.missouri.edu/view/Entry/223638.
} 
front of an audience by both playwrights, and I am interested in investigating what the intended messages of staging that violence might be within these works. Even though these works do not perfectly align with my line of inquiry, they are very useful models for this dissertation.

There are a few Masters theses and doctoral dissertations that examine representations of violence in theatre, but most examine works by playwrights in other parts of the globe. Gina Jimena Beltrán's dissertation, "Violence and Performance on the Latin American Stage," interrogates the works of Central and South American playwrights from the 1960 s that speak to political violence within the continent. ${ }^{55}$ These works use violence to respond to the cultural and sociopolitical violence happening in the respective countries of origin of the playwrights, and, as Beltrán argues, "represent the epicentre of catastrophe because their critical conceptualization of violence is performed through the violence of form." 56 Lukas Brasherfons' Masters thesis "Unlimited passion: the opposing schools of stage violence in Shakespeare and Kane" examines the function of violence as a dramaturgical tool of spectacle (based on Aristotle's definition) for William Shakespeare and Sarah Kane. ${ }^{57}$ Using both playwrights' works to represent endpoints of a binary, Brasherfons argues that both Shakespeare and Kane have written violence into their plays as exemplary dramaturgical devices that serve their respective plots and goals as playwrights; Shakespeare uses violence to further the plot of his plays in nearly all of his works, whereas Kane employs violence to create a space to examine

\footnotetext{
${ }^{55}$ Gina Jimena Beltrán, "Violence and Performance on the Latin American Stage” (Dissertation, University of Toronto, 2012).

${ }^{56}$ Ibid., 169.

${ }^{57}$ Lukas Brasherfons, "Unlimited Passion: The Opposing Schools of Stage Violence in Shakespeare and Kane” (Thesis, University of Iowa, 2017).
} 
the consequences of violence without glorifying it. ${ }^{58}$ This thesis highlights the effectiveness of violence (the staging of violent acts) as a dramaturgical tool used by playwrights to convey meaning, intention, or messages to represent larger issues as well as to advance the plot. Sarah Emily MacKenzie's dissertation "White Settler Colonialism and (Re)Presentations of Gendered Violence in Indigenous Women's Theatre" provides post-colonialist close readings of Canadian Indigenous Women's texts as sites of resistance and sources of empowerment for Canadian Indigenous women. Of these studies, Courtney Alimine Massie’s “Toward a Theatre of Empathy: Violence in the Plays of Timberlake Wertenbaker, Sarah Kane, and Marina Carr" is the closest to the work I seek to do with this dissertation as she is examining the violent acts of characters within works by women playwrights within a specific cultural and historical context (contemporary British drama). ${ }^{59}$ In her dissertation, Massie analyzes staged violence committed by female characters onstage and the potential effects that these acts may have on the audience. Massie's dissertation will be extremely helpful in the process of finding a structure and organization of analysis for works by multiple playwrights. Her dissertation relies upon mimesis and the mimetic model, and she argues that these acts of mimesis can yield a source of empathetic catharsis for the audience. The only dissertation I could find that examined violence in American drama is Richard Alan Bryan's dissertation "From the Voice to the Violent Act: Language and Violence in Contemporary Drama," which looks specifically at the language of violence (ex. speech

\footnotetext{
58 Ibid.

${ }^{59}$ Courtney Alimine Massie, "Toward a Theatre of Empathy: Violence in the Plays of Timberlake Wertenbaker, Sarah Kane, and Marina Carr” (University of Texas at Austin, 2017).
} 
acts) in works by American male dramatists. ${ }^{60}$ This dissertation could prove useful to mine as a reference point for how playwrights of a different gender within the same culture incorporate violence into their works as well as how those acts of violence function.

The most comprehensive treatment of the onstage presentation of violence committed by women that I am aware of is Nancy Taylor Porter's Violent Women in Contemporary Theatres: Staging Resistance (published in December 2017). In this new work, Porter uses a mixed methods approach to critically analyze contemporary works in which women are violent.

This book explores the nexus of theatre, gender studies, and psychology/sociology to consider the dialectical relationships between what 'actually' happens in our world when women engage in violence, how the events and their reception intercept with cultural understandings of gender, the development of plays about violent women, and how their productions actually or potentially impact audiences. ${ }^{61}$

Taylor Porter creates a foundational survey text of representations of violent women in contemporary theatre and develops violent women archetypes that are dominant in the groupings of texts she has created. For example, one chapter of the text examines contemporary adaptation of Greek myth across several different playwrights' works and what tropes these adaptations re-create or revisit. Taylor Porter then interprets the acts of violence performed by the female characters within these works as responses to systemic or structural violence, based on philosopher Slavoj Žižek’s definition of objective violence, which is violence that occurs on a larger scale that may not have individual

\footnotetext{
${ }^{60}$ Richard A. Bryan, "From the Voice to the Violent Act: Language and Violence in Contemporary Drama" (Dissertation, University of Tennessee - Knoxville, 2006).

${ }^{61}$ Nancy Taylor Porter, Violent Women in Contemporary Theatre: Staging Resistance (New York: Palgrave Macmillan, 2017), 2.
} 
perpetrators, but affects everyone in a society (for example, poverty, laws that inflict violence onto the populace, etc.). ${ }^{62}$ Taylor Porter primarily sees these acts of female violence as resistance to these forms of objective violence. Finally, while Taylor Porter covers a wide swath of works and archetypes, most, if not all, of the instances of violence are reactive to outside forces; the archetypes presented tend to include monsters, psychotics, or babes.

\section{Scholarship on Sheila Callaghan}

I am aware of one dissertation that critically analyzes the work of Sheila Callaghan. "‘if More Women Knew More Jokes...': The Comic Dramaturgy Of Sarah Ruhl And Sheila Callaghan", written by theatre scholar Jennifer Ann Goff, offers a close reading of Callaghan's That Pretty Pretty; or, The Rape Play, along with one of Callaghan's more recent works, Women Laughing Alone with Salad.$^{63}$ Goff's dissertation examines the comic devices Callaghan uses in the texts and how those devices navigate violence and the grotesque. This close reading could help speak to my dissertation by examining how the moments of violence can (and often are) read as comedic, and how that may influence or impact the meaning(s) of those moments. Goff's dissertation also includes a lengthy interview with Callaghan about her works and her approach to playwriting. There is also one Master's thesis that examines That Pretty Pretty; or The Rape Play, written by Kelda Lynn Jordan in $2010 .{ }^{64}$ American Theatre Magazine has featured several interviews with Callaghan, and several stories on Callaghan's extensive

${ }^{62}$ Ibid., 3.

${ }^{63}$ Jennifer Ann Goff, “'if More Women Knew More Jokes...': The Comic Dramaturgy of Sarah Ruhl And Sheila Callaghan" (Dissertation, Wayne State University, 2015).

${ }^{64}$ Kelda Lynn Jordan, "Perspectives on Women and Aggression Illustrated Through Caryl Churchill's Top Girls, Maria Irene Fornes' Fefu and Her Friends, and Sheila Callaghan's That Pretty Pretty; or, The Rape Play" (Thesis, California State University, Sacramento, 2010). 
body of work. ${ }^{65}$ Most often, her name appears alongside many others in articles about two of the organizations she helped create: 13P, an Off-Off Broadway playwriting group focused on the production of their works in full rather than developmental staged readings of their works, ${ }^{66}$ and The Kilroys. ${ }^{67}$ Her work has been anthologized in over thirty monologue books, scene study books, and play collections, including The Kilroys' own The Kilroys List: 97 Monologues and Scenes by Female and Trans Playwrights. ${ }^{68}$ Callaghan also has extensive creative credits in the television world, serving as a screenwriter for the hit series United States of Tara and as a producer and writer for Shameless. ${ }^{69}$

\section{Scholarship on Marisa Wegrzyn}

There is currently no existing scholarship on Marisa Wegrzyn. This study is the first to examine her works.

\section{Violence Theory}

Criminologists have made many contributions to violence theory, along with texts from other disciplines. Texts such as J. Peter Rothe's Driven to Kill: Vehicles as Weapons, James Alan Fox and Emma E. Fridel's “Gender Differences in Patterns and

\footnotetext{
65 "Awards and Prizes," American Theatre 24, no. 10 (December 2007): 20-21; Isaac Butler, "Chronicle of an Award Ungiven.," American Theatre 28, no. 1 (January 2011): 106; J. T. Rogers, "Deep Conditioning.," American Theatre 26, no. 4 (April 2009): 78-79; Jason Grote, "Joyce Among the Ruins.," American Theatre 23, no. 5 (June 5, 2006): 22-22; Sarah Hart, "Sheila Callaghan Writes Plays with One Finger on the Fast-Forward Button," American Theatre (October 2008): 28-30.

${ }^{66}$ John Patrick Bray, "Playwright as Auteur, Playwright as Producer: The Economics and Aesthetics of the Twenty-First Century American Playwright.," New England Theatre Journal 23 (August 2012): 57-78.

${ }^{67}$ Nicole Serratore, “The Kilroys Were Here (at the Lillys' Behest).," American Theatre 32, no. 5 (June 5, 2015): 12-13.

${ }^{68}$ The Kilroys, The Kilroys List: 97 Monologues and Scenes by Female and Trans Playwrights, ed. Anna Feinberg, vol. 1 (New York: Theatre Communications Group, Inc., 2017).

69 "Sheila Callaghan," IMDb, accessed September 17, 2018, http://www.imdb.com/name/nm3558363/.
} 
Trends in U.S. Homicide, 1976-2015," will be fruitful in understanding gender differences in criminal behavior. ${ }^{70}$

Feminists have also engaged with violence in several intersecting ways that may help my analysis of the violence as potential acts of feminist resistance, empathy, or empowerment. These works include "Girls and Violence: The Case for a Feminist Theory of Female Violence" by Kerry Carrington and "Performance matters more than masculinity: Violence, gender dynamics and mafia women" by Baris Cayli. ${ }^{71}$

\section{Violence and Theatre}

In addition to theoretical texts specifically related to violence theory, the few texts tying together the worlds of theatre and violence will be useful as models for my analysis. Works of this nature include Violence in American Drama: Essays on Its Staging, Meanings and Effects, Performing Gender Violence: Plays by Contemporary American Women Dramatists, Lucy Nevitt's Theatre \& Violence, Nancy Taylor Porter's Violent Women in Contemporary Theatre: Staging Resistance, Richard A. Bryan's "From the Voice to the Violent Act: Language and Violence in Contemporary Drama," Lukas Brasherfons' "Unlimited passion: the opposing schools of stage violence in Shakespeare and Kane," Gina Jimena Beltrán's "Violence and Performance on the Latin American Stage," Sarah Emily MacKenzie's "White Settler Colonialism and (Re)presentations of Gendered Violence in Indigenous Women's Theatre," Courtney Alimine Massie's "Toward a Theatre of Empathy: Violence in the Plays of Timberlake Wertenbaker, Sarah Kane, and Marina Carr," Kelda Lynn Jordan's “Perspectives on Women and Aggression

\footnotetext{
${ }^{70}$ Rothe, Driven to Kill: Vehicles as Weapons; James Alan Fox and Emma E. Fridel, "Gender Differences in Patterns and Trends in U.S. Homicide, 1976-2015," Violence and Gender 4, no. 2 (June 2017): 37-43.

${ }^{71}$ Carrington, "Girls and Violence: The Case for a Feminist Theory of Female Violence"; Cayli, "Performance Matters More than Masculinity: Violence, Gender Dynamics and Mafia Women."
} 
Illustrated through Caryl Churchill's Top Girls, Maria Irene Fornes's Fefu and Her

Friends, and Sheila Callaghan's That Pretty Pretty, or; The Rape Play," and Danielle

Szlawieniec-Law's “The Consequences of Representing Human Suffering, Distress, and/or Violence." 72

Performance of Identity

Texts regarding the performance of identity will be paramount in analyzing the relationship between violence and gender as well as other, intersecting identities within these works. Works to aid in my interrogation of the performance of identit(ies) within these works include performance studies texts, feminist texts and masculinity studies texts.

\section{Feminist Theory}

As I am using an intersectional, interdisciplinary feminist lens to view the works of Callaghan and Wegrzyn, I will rely on feminist scholarship both within theatre and performance studies as well as feminist theoretical texts. Feminist texts from theatre and performance studies include Judith Butler's Gender Trouble: Feminism and the Subversion of Identity and Bodies that Matter: On the Discursive Limits of 'Sex' and

\footnotetext{
${ }^{72}$ Alfonso Ceballos Muñoz, Ramón Espejo Romero, and Bernardo Muñoz Martínez, eds., Violence in American Drama: Essays on Its Staging, Meanings and Effects (Jefferson, North Carolina: McFarland, 2011); Barbara Ozieblo and Noelia Hernando-Real, eds., Performing Gender Violence: Plays by Contemporary American Women Dramatists, 1st ed. (New York: Palgrave Macmillan, 2012); Lucy Nevitt, Theatre \& Violence, Theatre\& (Palgrave Macmillan, 2013); Taylor Porter, Violent Women in Contemporary Theatre: Staging Resistance; Bryan, "From the Voice to the Violent Act: Language and Violence in Contemporary Drama"; Brasherfons, "Unlimited Passion: The Opposing Schools of Stage Violence in Shakespeare and Kane"; Beltrán, "Violence and Performance on the Latin American Stage"; Sarah Emily MacKenzie, "White Settler Colonialism and (Re)Presentations of Gendered Violence in Indigenous Women's Theatre" (Dissertation, University of Ottowa, 2016); Massie, "Toward a Theatre of Empathy: Violence in the Plays of Timberlake Wertenbaker, Sarah Kane, and Marina Carr"; Jordan, "Perspectives on Women and Aggression Illustrated Through Caryl Churchill's Top Girls, Maria Irene Fornes' Fefu and Her Friends, and Sheila Callaghan's That Pretty Pretty; or, The Rape Play"; Danielle Szlawieniec-Haw, "The Consequences of Representing Human Suffering, Distress, and/or Violence" (Dissertation, York University, 2018).
} 
Laura Mulvey's "Visual Pleasure and Narrative Cinema."73 Feminist texts outside of the realm of theatre and performance studies that aid in my analysis of the acts and texts include Julia Kristeva's Powers of Horror: An Essay on Abjection, Joan Acker's "Hierarchies, Jobs, Bodies: A Theory of Gendered Organizations," Tessa Wright's Gender and Sexuality in Male-Dominated Occupations: Women Working in Construction and Transport, Cara E. Rabe-Hemp's, “POLICEwomen or PoliceWOMEN?: Doing Gender and Police Work," and Rosemary Pringle and Susan Collings" "Women and butchery: Some cultural taboos." ${ }^{74}$ Femininity and hyperfemininity studies will also be useful in understanding the gender performances of some of the women characters. Texts include "Hyperfemininity: Measurement and Initial Validation of the Construct" by Sarah K. Murnen and Donn Byrne, "Hyperfemininity: Further Definition of the Construct" by Melissa McKelvie and Steven R. Gold, and "Seduction and Sex: The Changing Allure of the Femme Fatale in Fact and Fiction" by Kirsten Smith. ${ }^{75}$

\section{Masculinity Studies}

As I am exploring the disruption of gender for the characters in each of the plays, I will be employing masculinity studies to analyze the behavior and violence of both the men and women characters. As gender exists on a spectrum, it is important to look at how

\footnotetext{
${ }^{73}$ Butler, Gender Trouble: Feminism and the Subversion of Identity; Butler, Bodies That Matter: On the Discursive Limits of "Sex"; Laura Mulvey, "Visual Pleasure and Narrative Cinema," in Film Theory and Criticism: Introductory Readings, ed. Leo Braudy and Marshall Cohen (New York: Oxford University Press, 1999), 833-844.

${ }^{74}$ Kristeva, Powers of Horror; Acker, "Hierarchies, Jobs, Bodies: A Theory of Gendered Organizations"; Tessa Wright, Gender and Sexuality in Male-Dominated Occupations: Women Working in Construction and Transport (London: Palgrave Macmillan, 2016); Rabe-Hemp, "POLICEwomen or PoliceWOMEN?"; Rosemary Pringle and Susan Collings, "Women and Butchery: Some Cultural Taboos," Australian Feminist Studies 8, no. 17 (March 1993): 29-45.

${ }^{75}$ Murnen and Byrne, "Hyperfemininity: Measurement and Initial Validation of the Construct"; Melissa McKelvie and Steven R. Gold, "Hyperfemininity: Further Definition of the Construct," Journal of Sex Research 31, no. 3 (September 1994): 219; Smith, "Seduction and Sex: The Changing Allure of the Femme Fatale in Fact and Fiction."
} 
behavior aligns with either end of the gender spectrum to understand how a character's behavior in the plays align or subvert these gendered expectations. Therefore, masculinity studies is equally important to this analysis. These texts studying masculinity include Maurizio Catino's "Mafia rules. The role of criminal codes in mafia organizations," Valeria Pizzini-Gambetta’s “Organized Crime: The Gender Constraints of Illegal Markets," John Fox and Bob Pease's “Military Deployment, Masculinity and Trauma: Reviewing the Connections," Michael S. Kimmel's The Gender of Desire: Essays on Male Sexuality, and "Measuring a macho personality constellation" by Donald L. Mosher and Mark Sirkin. ${ }^{76}$

\section{Humor}

As all four of these works are categorized as comedies, works about humor and comedy will also be important for this analysis. Works regarding humor include "Postmodernity and the Use of Political Satire" by Lisa Colletta, All Joking Aside: American Humor and Its Discontents by Rebecca Krefting, and "'if More Women Knew More Jokes...': The Comic Dramaturgy of Sarah Ruhl And Sheila Callaghan” by Jennifer Ann Goff. ${ }^{77}$

\footnotetext{
${ }^{76}$ Maurizio Catino, "Mafia Rules. The Role of Criminal Codes in Mafia Organizations," Scandinavian Journal of Management 31, no. 4 (2015): 536-548; Valeria Pizzini-Gambetta, "Organized Crime: The Gender Constraints of Illegal Markets," in The Oxford Handbook of Gender, Sex, and Crime, ed. Rosemary Gartner and Bill McCarthy (New York: Oxford University Press, 2014), 448-467; John Fox and Bob Pease, "Military Deployment, Masculinity and Trauma: Reviewing the Connections.," Journal of Men's Studies 20, no. 1 (January 2012): 16-31; Kimmel, The Gender of Desire: Essays on Male Sexuality; Donald L Mosher and Mark Sirkin, "Measuring a Macho Personality Constellation," Journal of Research in Personality 18, no. 2 (June 1984): 150-163.

${ }^{77}$ Lisa Colletta, "Postmodernity and the Use of Political Satire," in Women and Comedy: History, Theory, Practice, ed. Diana Solomon et al. (Madison: Fairleigh Dickinson University Press, 2014), 207-218, accessed May 1, 2019,

http://search.ebscohost.com.proxy.mul.missouri.edu/login.aspx?direct=true \&db=nlebk\&AN=753604\&site =eds-live\&scope=site.; Rebecca Krefting, All Joking Aside: American Humor and Its Discontents (Baltimore: Johns Hopkins University Press, 2014), http://proxy.mul.missouri.edu/login?url=http://search.ebscohost.com/login.aspx?direct=true\&db=e700xna
} 


\section{ORGANIZATION}

Chapter One provides in-depth information on the topic, purpose, justification, and methods and procedures of this study. This chapter also includes information on the plays and playwrights, and a detailed literature review of the existing scholarship that examines onstage acts of women committing violence as well as relevant theoretical and critical works.

Chapter Two examines Callaghan's Roadkill Confidential as a confrontation to the brutality that those in American society consume on a daily basis. This chapter examines Trevor Pratt's use of vehicular violence as a disruption of her gender performance and the "doubling back" of FBI Man's hypermasculine performance as he surveilles Trevor through his male gaze. To analyze the vehicular violence, J. Peter Rothe's Driven to Kill: Vehicles as Weapons is central to the analysis and contextualization of Trevor's character.

Chapter Three analyzes Callaghan's That Pretty Pretty; Or, The Rape Play. This chapter employs theories of hyperfemininity, hypermasculinity, and gender parody to analyze the gender disruptions of the characters and their acts of violence. By destabilizing the gender of all the characters (both men and women), I suggest that Callaghan's work challenges the validity of gender roles and questions the trafficking of misogynist and sexist characterizations for entertainment. Using metatheatre, Callaghan deconstructs the male gaze, ending the work in silence.

Chapter Four analyzes Wegrzyn's Killing Women. Using Joan Acker's "Hierarchies, Jobs, Bodies: A Theory of Gendered Organizations" as a lens, I argue that 
Killing Women satirizes the inequalities in the workforce that women and mothers face, indicting all gendered workplaces as criminal enterprises.

Chapter Five examines Wegrzyn's The Butcher of Baraboo, with considerable reliance on Julia Kristeva's Powers of Horror: An Essay on Abjection to analyze the extent of Wegrzyn's critique of gender. By placing these violent characters in the conservative town of Baraboo, Wisconsin, more specifically in an interior domestic dystopia (a kitchen that is also a butcher shop) Wegrzyn reveals the darkness of heteronormative familial relationships (families as particularly brutal gendered hierarchal organizations) for women that transgress boundaries of acceptability.

Chapter Six will provide a comparative analysis of the findings of the previous chapters and draw conclusions regarding their meaning and significance for theatre artists, scholars, and activists as well as anyone interested in questions related to the meaning of violence in contemporary US culture and the relationship between gender and violence. This chapter will also provide strategies for violence designers as to how to stage these moments of violence to support the gender subversions within each act. In addition, I will discuss implications for future research. 


\section{CHAPTER TWO \\ Roadkill Confidential: "I am the keeper of the marvel"}

\section{Introduction}

I was first drawn to Roadkill Confidential when I was searching for plays in which violence was committed by women for my Masters thesis. I was fascinated by the protagonist of the piece, Trevor Pratt, whose behavior seemed calculated and methodical. Her violence did not seem to be in response or retaliation to another, which intrigued me. I was also intrigued by the use of a vehicle as the modality of her violence as I had never read a play in which a car was used to inflict violence on others. While I did not find the hand-to-hand combat that I was originally looking for in this work, I did find that this play haunted me and captivated me with questions about gender, violence, and how the two interact within the play.

Roadkill Confidential is inspired by actual events. On the morning of May 11, 2004, SUNY Buffalo art professor Steve Kurtz discovered that his wife was unresponsive in their bed and called $911 .{ }^{1}$ When the paramedics arrived and began an investigation, they discovered several vials and petri dishes in the basement of the Kurtz home. Hope Kurtz, Steve Kurtz's wife and co-founder of the biological art activist group Critical Art Ensemble, was declared dead at the hospital of an apparent heart attack. The FBI launched a probe into Hope Kurtz's death and began investigating Steve Kurtz for potential bioterrorism under the recently expanded Patriot Act. Kurtz was detained and questioned for twenty-two hours by the FBI, and all his scientific equipment was

\footnotetext{
${ }^{1}$ Lynne Duke, "The FBI's Art Attack: Offbeat Materials at Professor's Home Set Off Bioterror Alarm," The Washington Post (Washington, DC, June 2, 2004).
} 
confiscated from his home. While the grand jury did not indict Kurtz on bioterrorism charges, they did charge Kurtz with wire and mail fraud for obtaining potentially harmful organisms by way of the human genetics department at the University of Pittsburgh. It took four more years for a federal judge to dismiss the charges against Kurtz. ${ }^{2}$

Maria Striar, Producing Artistic Director and Founder of Clubbed Thumb Theater, attended a symposium about the Kurtz case in 2006. According to Striar, she and Sheila Callaghan were in conversation about a possible collaboration when "somehow stuff like that [the Kurtz case] came up in our conversation."3 Callaghan, Striar, and a series of three or four directorial collaborators began workshopping the piece that eventually became Roadkill Confidential. When director Kip Fagan joined the team, he saw the play through to production. ${ }^{4}$ Drawing inspiration from Kurtz's story, Callaghan and Clubbed Thumb selected surveillance as one of the major themes they wanted to explore:

We always knew that surveillance was part of the story, and [Callaghan] did say in the script that the scene titles would be projected. Once you get into the issues of surveillance, the play expands. In what way do we as an audience watch this? Are we going to see...the image that is seen by the FBI Guy? Do we get to see him watching it? Do we get to see it live? ${ }^{5}$

From the first drafts of the script, FBI Man was a strong voice in the play and became the representation of surveillance in the piece. Because FBI Man's voice became central to the storytelling, Striar became concerned about Trevor's role within the play. Trevor is

\footnotetext{
2 The Associated Press, "Charge Dropped Against Artist in Terror Case," The New York Times, April 22, 2008, sec. N.Y. / Region, accessed February 17, 2019, https://www.nytimes.com/2008/04/22/nyregion/22bioart.html.

${ }^{3}$ Micheline Auger, “Theaterspeak : Clubbed Thumb's Maria Striar Talks About The Development of Sheila Callaghan's Interesting New Play, Roadkill Confidential," Theatrespeak, n.d., accessed February 17, 2019, http://www.theaterspeak.org/2010/09/its-sort-of-one-of-those-things-where.html.

${ }^{4}$ Ibid.

${ }^{5}$ Ibid.
} 
the reimagined (cross-gendered) Kurtz within Roadkill Confidential, so Striar, Callaghan, and Fagan

spent a lot of time making sure that [Trevor] was there enough, and that there was a balance between the characters...there was a dramaturgical discovery of how to get more of her voice in, and the development of her voice, but then there was the discovery, once we had the full tech, that her voice was quite present and balanced with the FBI Guy, even though he obviously talks a great deal more. ${ }^{6}$

Finding Trevor's character through Kurtz's story became the central thematic message of the piece, which, for Striar, was "an investigation into fame, because I think she's tackling the numbness of the brutality that's especially the result of taking in so much over-mediated information, and obviously fame and the cult of celebrity is a big part of that."7

By understanding the inspiration for Roadkill Confidential, Callaghan's choices of character, modality of violence, and gender enhance the reader's understanding of how this play works as a disruption of gender norms. In this chapter, I will investigate how Callaghan's dramaturgical choices, especially the modality of Trevor's violence, a vehicle, as well as Trevor's gender performance, disrupt notions of gender and womanhood.

\section{Summary of Roadkill Confidential}

Roadkill Confidential, originally produced under the title Roadkill Confidential: $a$ noir-ish meditation on brutality, follows Trevor Pratt, a female visual artist looking for her next project. Noir, conjuring romanticized imagery of crime, danger, and deception, codes as a feminine exploration of a masculine topic — brutality. Told mostly from the

\footnotetext{
${ }^{6}$ Ibid.
}

${ }^{7}$ Ibid. 
perspective of FBI Man, the play is structured in a series of flashbacks starting from five months before the present until we catch up to real time at the very end of the play. FBI Man introduces us to Trevor. The scene shifts to Trevor driving her car. She accidentally hits a bunny, then slams on the brakes and begins to take photographs of the wounded animal. FBI Man jumps us five months forward in time. Frizzy-Haired Man, Trevor's lover, dies of tularemia, a disease carried by rodents and other small mammals like those Trevor is using for her art installation. In a direct address to the audience, FBI Man reveals that he is placing an undetectable hidden camera in the house to watch Trevor. The news is covering the death of Frizzy-Haired Man. Trevor begins to panic and discloses to her husband William that her project may get her into some legal trouble, but he is more than enthusiastic about the fame that may come with a project gone wrong. Trevor's neighbor Melanie, who is also dying from tularemia, knocks on the door of Trevor's studio and enters. FBI Man sees his opportunity to strike, so he enters the studio posing as a New York Times reporter. Trevor figures out that FBI Man is not who he is pretending to be, and although he attempts to control her with his magic missing eye, he fails. Trevor reverses his magical eye powers to trap FBI Man and interrogate him, then reveals, in the presence of assembled photographers, her final masterpiece: Melanie, dying, strapped to the platform with all the dead and dying animals. Trevor owns her moment in the spotlight with the gathered photographers, then allows herself to be escorted out of the studio by the FBI Man. Melanie then sings a song with the animals about her dreams of waiting for her love to join her. ${ }^{8}$

\footnotetext{
${ }^{8}$ Sheila Callaghan, "Roadkill Confidential," in Lascivious Something, Roadkill Confidential, That Pretty Pretty; or, the Rape Play: Three Plays (Berkeley, CA: Soft Skull Press, 2011), 109-228.
} 


\section{Character Gender Disruption: Trevor Pratt}

Perhaps Callaghan's most notable deviation from the original story that inspired the work is her use of a female instead of a male protagonist. This change follows the tradition of many American female, feminist playwrights, including Susan Glaspell, of which critic Maida Castellun wrote, "Miss Glaspell has left the conventions of the stage behind - she has chosen a woman instead of a man to incarnate the restless audacious, creative spirit."

Trevor Pratt as a character challenges several gender norms. Her first name, Trevor, is much more commonly given to boys than girls. ${ }^{10}$ Coming from Welsh, roughly translating from "big settlement" or "big village," the name "Trevor" transferred into Gaelic for "industrious [and] prudent." "Her surname, Pratt, comes from the Old English word "prætt" meaning "trick" or "cunning and astute."12 These qualities_-industrious, prudent, cunning, and astute_-are more often associated with masculinity than femininity. ${ }^{13}$ In the dramatis personae, Callaghan describes Trevor as "female, thirty, furtive and glamorous."14 The last two adjectives in this list seem somewhat contradictory; whereas, 'glamorous' is often associated with attention-seeking, a furtive nature somewhat unsettles that image. The audience also learns that Trevor is "allergic to

\footnotetext{
${ }^{9}$ Maida Castellun, “The Plays That Pass,” New York Call (New York, April 30, 1922), sec. 4.

10 "Boy or Girl? Gender Popularity of the Name 'Trevor,"” accessed April 24, 2019, http://www.babynameshub.com/gendercompare.cfm?Name=Trevor.

11 "Trevor Name Meaning \& Trevor Family History at Ancestry.Com," accessed December 9, 2018, https://www.ancestry.com/name-origin?surname=trevor.

12 "Pratt Name Meaning, Family History, Family Crest \& Coats of Arms," HouseOfNames, accessed December 9, 2018, https://www.houseofnames.com/pratt-family-crest.

${ }^{13}$ Monica Biernat and Amanda K. Sesko, "Gender Stereotypes and Stereotyping: A Cognitive Perspective on Gender Bias," in Gender, Sex, \& Sexualities: Psychological Perspectives, ed. Nancy K. Dess, Jeanne Marecek, and Leslie C. Bell (New York: Oxford University Press, 2018), 171-194.

${ }^{14}$ Callaghan, "Roadkill Confidential," 112.
} 
apples," 15 which could be an allusion to the biblical archetype Eve in the garden of Eden, who famously brought about the downfall of humanity through eating, and then tempting Adam with, an apple from the "tree of knowledge of good and evil." Trevor's allergy to apples could be representative of her rejection of femininity and the archetypal feminine role of "temptress."

Trevor is a successful visual artist (at a fairly young age), a rare circumstance for female artists in the U.S. Statistics from recent studies on the fine and visual art world regarding artists featured in the major galleries in New York City from 2016-2017 reveal that only thirty percent of artists featured are women. ${ }^{16}$ An overwhelming number of these artists are also white and attended private universities and institutions, which could be a reflection of the social class, upbringing, and culture these visual artists are growing up in and emerging into. ${ }^{17}$ From her husband William's art history lecture in the middle of the play, the audience learns that Trevor gained her fame eight years prior to the events of the play with her exhibit entitled Impact. During this lecture, William reveals that Trevor was his former student. William's first wife Diane died in a head-on collision, and Trevor found the photographs of the accident in William's bedroom. She enlarged photographs from the accident and hung them in a gallery, which flung her into fame. Trevor's masterwork reveals her fascination with violence, brutality, and pain, themes that are not typically associated with femininity or feminine interests. In addition, William also compares Trevor to a male visual artist, Guillermo Vargas, who rose to

\footnotetext{
${ }^{15}$ Ibid., 138.

${ }^{16}$ Henri Nuendorf, "Study: 80\% of Artists Represented at NYC's Top Galleries Are White," Artnet News, last modified June 2, 2017, accessed February 20, 2019, https://news.artnet.com/art-world/new-yorkgalleries-study-979049.

${ }^{17}$ Ibid.
} 
fame for allegedly starving a dog to death in an art gallery. ${ }^{18}$ In addition to the comparison of Trevor to Vargas, the subject of the artwork is the mangled body of her husband's first wife. The bloody carnage and brutality displayed in her artwork further undermines Trevor's "feminine" gender identity.

Although married to William (her former art professor), Trevor is in bed with her lover, Frizzy-Haired Man, in the second scene of the play. This sexual infidelity is another disruption of traditional gender expectations that men are more likely to cheat on their wives with a younger female lover/protegee. Moreover, Trevor is apparently the first to tire of the extra-marital liaison. While they are in bed, Frizzy-Haired Man finds a breakup note from Trevor. In an attempt to psychoanalyze why she would want to end things with him, Trevor responds, "You're much cuter when you're focused on pleasing me." ${ }^{19}$ Frizzy-Haired Man bemoans "I need a little break / my jaw hurts," indicating that Frizzy-Haired Man has repeatedly been performing oral sex on Trevor. ${ }^{20}$ Again, this is another gender disruption regarding gendered sexual acts. After this exchange, FrizzyHaired Man reveals to Trevor that he has touched the animals under the tarp, which eventually causes him to die of tularemia. Trevor uses Frizzy-Haired Man as a sexual object; she treats him with condescension, and when he no longer serves his purpose to please Trevor, he dies by her (indirect) hand.

After the initial car accident, Trevor has nightmares, hand-shaking, loss of appetite, and difficulty sleeping. These symptoms, which she reports to Frizzy-Haired

\footnotetext{
${ }^{18}$ David Mikkelson, "FACT CHECK: Guillermo Vargas: Dog Starved for Art Exhibit," Snopes.Com, accessed March 20, 2019, https://www.snopes.com/fact-check/starving-dog-art/.

${ }^{19}$ Callaghan, "Roadkill Confidential," 118.

${ }^{20}$ Ibid.
} 
Man five months after the initial car accident, resemble symptoms of Post-Traumatic Stress Disorder. ${ }^{21}$ Although women are diagnosed with Post-Traumatic Stress Disorder more frequently than are men, ${ }^{22}$ the Disorder in women is more often a result of sexual assault or sexual violence committed against, not by them. Trevor has not experienced this form of trauma within the course of the play, but as a result of her violent actions, her repeated vehicular "accidents," which are more indicative of the circumstances that cause men to be diagnosed with Post-Traumatic Stress Disorder (for example, acts of war, accidental trauma like a car accident, etc.). Later in the play, Trevor smokes a marijuana joint from her step-son Randy's stash with the FBI Man (disguised as the exterminator), an activity which Trevor may be using as a coping mechanism to deal with the heightened "fight or flight" response she is experiencing after several intentional car "accidents" with small animals on the road. ${ }^{23}$ Trevor describes feeling on edge waiting for the FBI to close in and also displays negative thoughts about herself and the world, symptoms which also fall in line with a potential Post-Traumatic Stress Disorder diagnosis. According to the National Center for Post-Traumatic Stress Disorder,

Women are more likely to be jumpy, to have more trouble feeling emotions, and to avoid things that remind them of the trauma than men. Men are more likely to feel angry and to have trouble controlling their anger then women. Women with PTSD are more likely to feel depressed and anxious, while men with PTSD are more likely to have problems with alcohol or drugs. Both women and men who experience PTSD may develop physical health problems. ${ }^{24}$

\footnotetext{
21 “NIMH » Post-Traumatic Stress Disorder," accessed February 20, 2019, https://www.nimh.nih.gov/health/topics/post-traumatic-stress-disorder-ptsd/index.shtml. 22 Ibid.

23 Ibid.

24 "How Common Is PTSD in Women? - PTSD: National Center for PTSD," General Information, accessed April 24, 2019, https://www.ptsd.va.gov/understand/common/common_women.asp.
} 
Trevor is a fusion of the two stereotypes of emotional responses to Post-Traumatic Stress Disorder; she has difficulty feeling emotions, yet she self-medicates. She does not avoid the trauma, but rather continues to enact it. As a result, she disrupts the gender norms associated with Post-Traumatic Stress Disorder by the circumstances in which she received this disorder, her lack of reporting the incident that has occurred, her continuation of the behavior that causes the trauma, and self-medication.

Feeling the pressure of her inevitable capture, Trevor buys one-way tickets to Puerto Rico for William and Randy, sending them away before the firestorm. This act is another subversion of gender as Trevor performs the role of protector of William and Randy and, as FBI Man later notes, she protects the innocent bystanders of her violence/work, in the mode of "The captain going down with her ship." 25 In most scenarios, especially when this metaphor is used, those who take the blame or take the fall on behalf of others tend to be men in an attempt to rescue women and children (a la Titanic).

While Trevor is unquestionably the play's protagonist, her character is not the only one within the confines of the script who manifests complex gender behaviors.

\section{Character Gender Disruption: FBI Man}

The gendered performance of the FBI Man conforms to such a degree of behaviors coded masculine that they might be interpreted as representations of hypermasculinity. Psychologists Donald L. Mosher and Mark Sirkin have identified "three related components" of hypermasculinity (also referred to as the "macho

${ }^{25}$ Callaghan, "Roadkill Confidential," 214. 
personality constellation"): (a) calloused sex attitudes toward women, (b) a conception of violence as manly, and (c) a view of danger as exciting., ${ }^{26}$ In their study, Mosher and Sirkin noted some common behaviors:

The macho man... wants to be the center of attention and engages in behavior which wins the notice of others; enjoys exciting activity, especially if danger is involved, and does not avoid risk of bodily harm...attempts to control or influence his environment and to influence or direct other people; does not give sympathy and comfort or offer others a "helping hand"; is not concerned with keeping personal effects and surroundings neat and organized; and does not describe himself in terms judged as desirable. ${ }^{27}$

FBI Man enacts many of these behaviors throughout the play. In his profession, he engages in dangerous and exciting activity by investigating and tracking criminals. He attempts to control and influence the environment by placing surveillance cameras in Trevor's home, and he attempts to influence the final product of Trevor's art project. Callaghan describes FBI Man's surveillance studio as containing a “crappy smelly bed...Gross unwashed coffee mug [and a] flickering bare bulb." ${ }^{28}$ FBI Man engages in slovenly behavior like drinking two-day old coffee because he "want[s] to taste the rot."29 He also fails to save Melanie once she is bound to Trevor's art project, and he frequently makes self-deprecating comments.

Described in the dramatis personae as "male, thirties to forties, cool, level, dangerous, mysterious, jaded," ${ }^{30}$ FBI Man strongly evokes the trope of the detective popularized by film noir and performed by iconic male stars like Humphrey Bogart and Robert Mitchum. He is generally unemotional and aloof, but also has a vendetta and is

\footnotetext{
${ }^{26}$ Mosher and Sirkin, "Measuring a Macho Personality Constellation," 151.

${ }^{27}$ Ibid., 161-162.

${ }^{28}$ Callaghan, "Roadkill Confidential," 147.

${ }^{29}$ Ibid.

${ }^{30}$ Ibid., 112.
} 
motivated by righteousness. He is the character who starts the play by introducing us to Trevor; in the stage directions, Callaghan indicates, "The FBI MAN appears...sinister, weary, commanding." "31 By describing him as "sinister," Callaghan positions FBI Man as an anti-hero, but he will later be revealed as the antagonist. He presents his story in a “commanding" fashion, by presenting himself as the consummate professional FBI Man in a classic film noir narrator fashion; Callaghan wants the audience to heed the warning of FBI Man and to believe his side of the story. These actions also correspond with the hypermasculine tendency to claim the center of attention, ${ }^{32}$ and the best way FBI Man can do that is by directly addressing the audience, having control over the speed and action of the plot, and dictating to the audience how they should feel about each character. Primarily, FBI Man functions as a narrator of the plot through his perspective. He significantly inflates his importance when he speaks to the audience:

I won't lie I'm at my best

When the fate of the nation is at hand

Domestic situations however are not my specialty International was always my bag

He opens a trunk of costumes. He dons an exterminator outfit, "Bugs B-Gone," and a cap.

Like any good agent I adapt. ${ }^{33}$

In this passage, FBI Man conveys a sense of urgency to the audience by claiming that the "fate of the nation is at hand" and that he is "at his best" when this scenario occurs. He also refers to himself as a "good agent" after admitting the minor flaw of being more of

\footnotetext{
${ }^{31}$ Ibid., 115.

${ }^{32}$ Mosher and Sirkin, "Measuring a Macho Personality Constellation," 162.

${ }^{33}$ Callaghan, "Roadkill Confidential," 128.
} 
an expert in international matters of security than in domestic. Any potential flaw he presents, he reconfigures, rebrands, and remarkets into a positive affirmation about himself.

Similar manipulative behavior can be seen in a long direct address to the audience in which he is attempting to show them a high-tech surveillance system that no one in the audience can see. While demonstrating that he has the tech on his finger, he shares with the audience the exorbitant cost, the innovation of the camera and its ability to be undetectable, and the fact that he is the only person in the world who can be trusted with such technology. ${ }^{34}$ In a dramatic reveal, FBI Man exposes to the audience the true reason that he is trusted with such a precious device:

FBI MAN (cont.)

Why Give it to $m e$, you ask?

I seem like an ordinary fellow.

Hygienic but not suspiciously so

Decent taste in footwear

Marginally fit on a good day

A sheen of competence akin to a mid-level executive

I am not an opera

I am not a threat

I'm a block of clay-shaped clay

I could even be you.

So.

Why is it me holding this tiny precious box?

The simple answer?

Because I'm a patriot.

He drops his trousers. Beneath, he wears American flag boxer shorts. ${ }^{35}$

\footnotetext{
${ }^{34}$ Ibid., 134-138.
}

${ }^{35}$ Ibid., 136. 
In this excerpt, FBI Man demonstrates that his loyalty to his country, in one of the most masculine ways one could demonstrate, far surpasses the commitment any other American could possibly have. This moment also provides a great snapshot into the sometimes erratic or inconsistent behavior that hypermasculine men display. Mosher and Sirkin also describe the macho man as "playful, pleasure-seeking, frivolous...illogical; hasty, reckless, impulsive; fearless, adventurous, risk-taking; imprecise....and inconsistent." 36 By dropping his trousers to reveal American flag boxers to the audience, FBI Man demonstrates that he is playful in his patriotism, and that his choice to drop his trousers for the audience to see his devotion to his country reads as impulsive and risktaking. This choice seems incongruous with the rest of his performance of hypermasculinity by being the cool, calm, and calculating man of mystery, but inconsistency is part of the hypermasculine gender presentation. This disruption troubles the ideas of an essential, "natural," or stable gender identity.

As mentioned earlier in this section, the macho man "does not describe himself in terms judged as desirable." ${ }^{37}$ While he may appear as an "average joe” visually, FBI Man's commitment to serving his country, even at the expense of losing a toe, a fingernail, and an eye, makes him the most qualified person to hold this job and to possess this technology. ${ }^{38}$ In fact, these missing parts, which could be read as allusions to emasculation, are instead presented as assets to help FBI Man do his job; without his missing eye, FBI Man would not be able to perform magical powers to force those around him to tell him the truth and guide him in the right direction to track Trevor and

\footnotetext{
${ }^{36}$ Mosher and Sirkin, "Measuring a Macho Personality Constellation," 162.

${ }^{37}$ Ibid.

${ }^{38}$ Callaghan, "Roadkill Confidential," 136.
} 
stop her. FBI Man's hypermasculine performance is taken to the extreme by inflating his self-importance to the point that it becomes absurd, and it is this absurdity that makes the hypermasculine performance "double back" and queer itself. In this sense, FBI Man could be queering gender through a parodical hypermasculine performance. Feminist theorist Judith Butler interrogates gender parody in her text Gender Trouble: Feminism and the Subversion of Identity:

Although the gender meanings taken up in these parodic styles are clearly part of hegemonic, misogynist culture, they are nevertheless denaturalized and mobilized through their parodic recontextualization... The loss of the sense of 'the normal,' however, can be its own occasion for laughter, especially when 'the normal,' 'the original' is revealed to be a copy, and an inevitably failed one, an ideal that no one can embody. In this sense, laughter emerges in the realization that all along the original was derived. ${ }^{39}$

In his repeated attempts to perform as a macho man, FBI Man fails at each turn. This creates a moment of comic relief, which Callaghan has expertly crafted to undermine and queer FBI Man's hypermasculine performance. It is a performance that manifests a “camp" sensibility, as theorized by Susan Sontag in her famous essay "Notes on Camp," ...the essence of Camp is its love of the unnatural: of artifice and exaggeration... All Camp objects, and persons, contain a large element of artifice... What Camp responds to is 'instant character'...Character is understood as a state of continual incandescence--a person being one, very intense thing. This attitude toward character is a key element of the theatricalization of experience embodied in the Camp sensibility... ${ }^{40}$

Because FBI Man is an extreme, hypermasculine form of what society expects of an FBI Man, his gender performance becomes Camp. The comedy is heightened by his sincerity; if FBI Man’s performance was insincere, the Camp of his gender performance

\footnotetext{
${ }^{39}$ Butler, Gender Trouble: Feminism and the Subversion of Identity, 188-189.

${ }^{40}$ Susan Sontag, "Notes on Camp," in Theater of the Avant-Garde 1950-2000: A Critical Anthology, ed. Robert Knopf and Julia Listengarten (New Haven: Yale University Press, 2011), 312-320.
} 
would be unsuccessful. Using Camp humor as a strategy deepens Callaghan's parody of masculinity through FBI Man's gender performance.

\section{Character Gender Disruption: Randy}

Randy, Trevor's teenage stepson, often conforms to masculine gender presentation and, like FBI Man, crosses over into hypermasculine behavior. In fact, Randy performs many of the masculine behaviors identified by Mosher and Sirkin that FBI Man seems to lack:

The macho man does many things 'just for fun,' spends a good deal of time participating in games, sports, social activities, and other amusements; does not want to understand many areas of knowledge and does not value synthesizing ideas or logical thought; tends to act on the 'spur of the moment,' without deliberation, giving vent readily to feelings, wishes, and volatile emotions... [and] enjoys combat and argument and is sometimes willing to hurt people to get his way or to 'get even." 41

Randy is almost always seen listening to music through large headphones in an attempt to tune out the world around him. Evoking a moody, angsty, teenage boy, Randy often shouts his lines (indicated by the lines being in all caps) and spews profanities, which is a way for Randy to vent his feelings and volatile emotions. He also uses hypersexual language frequently; one particularly explicit instance is the moment when he claims to Trevor that he broke into her studio and "Fondled all the girl rabbits / Licked their little bunny twats." 42 Even his name is hypersexual, as "randy" is a slang term for a state of sexual arousal. Seeming unable to channel his aggression and angry mood swings, Randy often manifests his emotions physically through "fight-dancing," and stabbing his food with forks from his extensive fork collection. In one instance, Randy uses a shrimp fork

${ }^{41}$ Mosher and Sirkin, "Measuring a Macho Personality Constellation," 161-162.

${ }^{42}$ Callaghan, "Roadkill Confidential," 159. 
to stab his breakfast sausages as he eats them. ${ }^{43}$ This imagery connotes a phallus stabbing another phallus for consumption by a male character; Randy is consuming masculinity in all its forms. He evokes an "angry young man" stereotype (not unlike James Dean in Rebel without a Cause) that is, like that of FBI Man's, so extreme that it falls into Camp: “. . . art that proposes itself seriously, but cannot be taken altogether seriously because it is 'too much.", 44

\section{Character Gender Disruption: William}

Unlike FBI Man and his son Randy, William presents a different kind of masculinity in his gender presentation - that of the academic yet awkward adult man. As an art professor, he attempts to connect to his youthful students in "hip" ways. William also distances himself from Trevor when he acknowledges a conflict of interest in discussing Trevor and her work. William often speaks in academic gibberish when speaking to Trevor about her work (which he has never seen), placing him in the stereotype of the dreaded "mansplainer." 45 The main deviation that William makes from a masculine presentation of gender is that he is often passive when it comes to Trevor. He does not assert himself often when it comes to Trevor's abrupt and eccentric behavior; he does not try to stop Trevor from leaving the dinner party they are hosting when she excuses herself to work on her project even though they have company present. ${ }^{46}$ William also depends entirely on Trevor's legacy for his sense of purpose and self-worth as an art historian. He mentions during his lecture about Trevor's work that he has a forthcoming

\footnotetext{
${ }^{43}$ Ibid., 151.

${ }^{44}$ Sontag, "Notes on Camp," 318.

45 “Mansplaining | Merriam-Webster," accessed June 30, 2019, https://www.merriam-webster.com/wordsat-play/mansplaining-definition-history.

${ }^{46}$ Callaghan, "Roadkill Confidential," 139-140.
} 
book regarding Trevor's work, which could greatly impact his academic career should it be successful. ${ }^{47}$ When Trevor informs William that she has completed her art project he states:

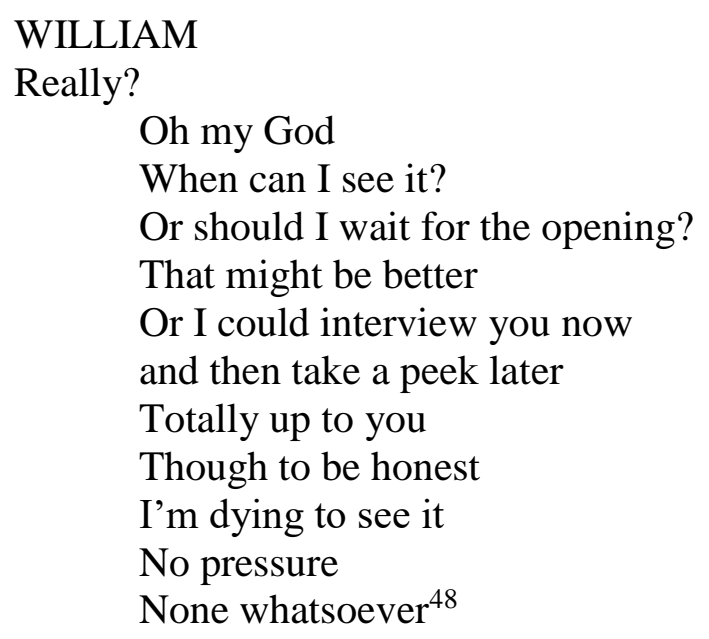

Each time William asks for what he wants, he backpedals to accommodate Trevor's potential needs. When he begins to question Trevor's choice to send him and Randy away she responds that William is the reason she is doing this:

TREVOR (suddenly vicious)

Okay, look.

I'm, I'm sick.

Sick of your intellectual postscripts

your fame whoredom

your cloying regard

And I'm so fucking sick

of being the one thing

that makes your career feel important.

A beat.

WILLIAM picks up his papers.

WILLIAM

If this is how you need to be supported, fine.

${ }^{47}$ Ibid., 144-145.

${ }^{48}$ Ibid., 210. 
But you didn't need to say any of that. ${ }^{49}$

Even in the face of Trevor's wrath, William makes the choice to acquiesce and to remain passive to her demands. He agrees to go to Puerto Rico with Randy before Trevor reveals her project to the world. His passivity reads as feminine, and this feminine performance disrupts his masculine performance of a mansplaining, philandering professor who loves to hear himself talk.

\section{Character Gender Disruption: Melanie}

Melanie, Trevor's cheerful neighbor, serves as a representation of hyperfemininity in Roadkill Confidential. Hyperfemininity has been defined by psychologists Sarah K. Murnen and Donn Byrne as "exaggerated adherence to a stereotypical feminine gender role." ${ }^{" 50}$ Melanie performs this "exaggerated adherence" in several ways; Melanie visits Trevor's home on several occasions (often with food in tow) in bizarre attempts to bond with Trevor and create a "sisterly" bond. Melanie maintains continuity with feminine gender presentation as she appears friendly, empathetic, kind, caring, and domestic. She constantly seeks Trevor's approval, and when she does not receive it, she turns to William for advice as to how to move forward in her attempted friendship with Trevor. About halfway through the play, Melanie brings over cobbler for Trevor. In their conversation, Melanie confesses to having an affair with William. While Melanie has been attempting to connect with Trevor, she has also betrayed her and her trust by violating the bonds of Trevor's marriage to William (which, as previously stated, Trevor does as well). In response, Trevor calls Melanie "a cunt," ${ }^{11}$ then bursts into

\footnotetext{
${ }^{49}$ Ibid., 214.

${ }^{50}$ Murnen and Byrne, "Hyperfemininity: Measurement and Initial Validation of the Construct," 480.

${ }^{51}$ Callaghan, "Roadkill Confidential," 181.
} 
hysterical laughter. Melanie joins in in this laughter to try to appease her and to conform to Trevor's odd sense of humor, but is then ordered by Trevor to do the following things:

TREVOR

Go away now

Get a haircut

MELANIE

Um

TREVOR

Buy a bright red belt

Take a long clarifying walk ${ }^{52}$

Trevor instructs Melanie to change aspects about her appearance that could make Melanie more or less feminine depending on how the costuming portrays these choices. By telling Melanie to "get a haircut," Trevor instructs Melanie to enact a feminine behavior that women stereotypically enact after a major life change, like a breakup. Relationship and sex educator Laura Berman argues that women tend to cut their hair after a breakup as a coping mechanism, arguing "it is natural to make changes to your external body in the hopes that it will make you feel better internally as well...There is something about a drastic cut that can feel cathartic...like you are cutting off the dead weight and becoming lighter and freer." ${ }^{53}$ Buying new clothes and taking a long walk could also give Melanie this catharsis. As these behaviors code feminine, Trevor encourages Melanie to turn away from seeking connection with Trevor and William and instead turn towards Melanie's own femininity as a coping mechanism. After this exchange, Melanie does as she is told and is wearing a new, bright red belt when she is approached by FBI Man in disguise. Through his surveillance of Trevor, FBI Man thinks

\footnotetext{
${ }^{52}$ Ibid., 181-182.

${ }^{53}$ Marianne Mychaskiw, "This Is Why People Cut Off Their Hair After a Breakup," InStyle, last modified October 10, 2016, accessed April 29, 2019, https://www.instyle.com/news/haircut-breakup-connection.
} 
that Melanie may be the weakest link within the chain of Trevor's associations and could be coerced to work for him, so he targets Melanie by becoming friendly with her. He gets her drunk, and Melanie leads FBI Man to Trevor's studio in the woods. This is another instance in which Melanie betrays Trevor's trust and violates the boundaries that Trevor has clearly expressed. Melanie pays for this betrayal with her life. FBI Man encourages Melanie to touch one of the animals, and she does. Melanie confesses this to Trevor when she is in the final throes of tularemia and becomes part of Trevor's project as a result. The final image the audience sees of Melanie sends a profoundly gendered message. She is lying with the mutilated animals as part of the art installation, reminiscent of the celebrity women who pose lying on a fur carpet or surrounded by fur. The display of the body of a dying woman among a collection of mutilated, small, fuzzy animals, might be read as representing the mutilation of what society deems beautiful and feminine. It might also be read as Camp. The addition of Melanie and the animals singing a song about waiting is also a gendered message, conveying the idea that while the woman is on display, the only thing she can do is wait for someone to save her, invoking the image of the damsel in distress, passively waiting for someone to rescue her.

Using these character analyses as a starting point, I will now more closely examine Trevor's onstage acts of violence within Roadkill Confidential.

\section{Onstage Violence in Roadkill Confidential}

Callaghan's creation of a female protagonist who enacts violence to cause death deviates from the original story in which the only death that occurred was due to natural causes. This deviation from the original scenario, using a car to commit murder, has specifically gendered connotations. J. Peter Rothe, former Professor with the University 
of Alberta School of Public Health, has written a comprehensive book on the topic of vehicular violence titled Driven to Kill: Vehicles as Weapons. Throughout the text, Rothe almost exclusively refers to vehicle violence as masculine or performed by men. In the introduction, he presents some basic tenets that support his arguments regarding this kind of violence:

- Driver behaviour is influenced by media messages that introduce criminality as a preferred way of life-an urban, inner-city, romanticized notion of machismo, strength, control, and attitude. [...]

- Males still dominate Western society, ruling 'automobility.' [...]

- A type of bravado can characterize some emotions or feelings, especially in men who believe that personal problems such as a broken romance or loss of a job demand a dramatic release. ${ }^{54}$

Trevor is intentionally disrupting this assumption of gender performativity. As a woman, she challenges gendered notions of who can perform "machismo" and who rules "automobility," and she employs a sense of "bravado" by committing these acts of vehicular violence and vehicular poaching without apparent concern for being caught in the act.

Rothe provides the first concrete definition of what he terms "vehicle violence:"

Vehicle violence - sometimes called roadway violence-is usually conceptualized as a complex interplay of four major factors: the person, situation, vehicle, and culture. These factors interact when a driver confronts a "triggering" event (an event that causes or determinately influences a violent reaction). ${ }^{55}$

These four factors can manifest in different ways and contexts. Person-related factors of vehicular violence include "the perpetrator's personality, belief systems, age, gender, and transient states of being, such as stress and pressures at the time of an incident."

\footnotetext{
${ }^{54}$ J. Peter Rothe, "Introduction," in Driven to Kill: Vehicles as Weapons (Alberta, Canada: The University of Alberta Press, 2008), 5.

${ }^{55}$ Ibid., 4.

${ }^{56}$ Ibid.
} 
Situational factors relate to the given circumstances of the event - whether that be road conditions, predispositions to anger and aggression (such as Post-Traumatic Stress Disorder), and work and family conflicts. ${ }^{57}$ Vehicular factors are tied to the role that the vehicle plays in the crime, and can fall in one of three layers of relevance: the mediate, intermediate, and immediate zones. "These zones reflect a kind of continuum, whereby each one represents a degree of closeness to the heart of a violent behaviour." 58 For example, a car used as a form of transport for a kidnapping victim is in the intermediate zone, but when a car is used as a weapon directly, it is in the immediate zone. Cultural factors that may impact vehicular violence include norms of the society, media coverage and portrayal of vehicle violence, and moral values.

Driving a vehicle involves complying with a number of social conventions. Many influences, however, contribute to the formation of a violent attitude and aggressive driver behaviour. These influences include institutions like the family (e.g., poor role modelling); education (e.g., student competition, bullying, cooperation); the media (e.g., violent movies, dramatization of the news); sports and recreation (e.g., demolition derbies, computer games); government policies (e.g., human rights, property ownership rights); and corporations (e.g., competition, executive greed, profit). Collectively, these and others form a social context with wide implications for our attitude and behaviour in general, and behaviour leading to vehicle violence in particular. ${ }^{59}$

As my approach for analyzing the moments of violence within the texts is multi-modal and intersectional, this framework created by Rothe will be a major tool of analysis for Roadkill Confidential. Finding representations of vehicular violence of any kind is rare within the context of a theatre, which makes this piece stand out as a representative work containing aggressive and violent acts by a woman.

\footnotetext{
57 Ibid.

${ }^{58}$ Ibid., 6.

${ }^{59}$ J. Peter Rothe, "Section I: The Social Context," in Driven to Kill: Vehicles as Weapons (Alberta, Canada: The University of Alberta Press, 2008), 9.
} 
Nearly all the onstage violence in Roadkill Confidential serves as a transition within the play. At times, these moments may be occurring simultaneously with the action of the following scene. The first instance of onstage violence, however, described on the second page of the script, is the sole focus of the audience when it occurs:

TREVOR is suddenly in her car, driving.

THUMP. Squeal of tires. She pulls over.

She has hit a bunny accidentally. She stares at it. Emotion: compassion, revulsion, fascination, etc.

She retrieves a camera and photographs the bunny dying. Then-she gets an idea. She puts on a pair of work gloves. ${ }^{60}$

Although this act of violence was unintentional, placing it technically outside the definition I have made for the analysis of violent moments within these works, this moment serves as the inciting incident of the play, therefore making it an important moment to analyze. Moreover, later intentional acts are re-creations of this moment.

While this is the first act of violence within the play, its intentionality is markedly different from the others. Callaghan specifically identifies the animal that Trevor has struck with her vehicle as a "bunny." This word choice, over "rabbit," "hare," or choosing another animal altogether, evokes a gendered message of femininity. "Bunny" has become a signifier for hyper-femininity and female sexuality through the popularization of the Playboy Bunny. While this may seem like a small semantic detail, the fact that Trevor collides with (and destroys) the iconography of hyper-femininity and female sexuality suggests that Trevor is not one to conform to these standards. Although this “bunny-killing" is an accident, as denoted by Callaghan's stage directions, the

${ }^{60}$ Callaghan, "Roadkill Confidential," 116. 
incident does qualify as an incident of vehicle violence, specifically roadkill, according to Rothe:

Each year thousands, if not millions, of animals are killed on public roadways. Deer, skunks, porcupines, squirrels, groundhogs. birds, mice, and rabbits are dominant species that die under the wheels of the automobile. The problem is becoming more serious as the number of vehicles on the road increases. ${ }^{61}$

While there was no intention behind the roadkill accident on Trevor's part, this event will set in motion multiple acts of intentional violence later in the play. Her vehicle is the primary weapon in this act of violence, making this act one that is in the "immediate" zone of relevance. ${ }^{62}$ Trevor exits the vehicle to see what she hit, and when she sees the carnal damage she has accidentally caused to the bunny, she goes through several emotions, including "compassion, revulsion, [and] fascination." With the first emotion in this list being compassion, Callaghan reminds us that Trevor is someone who can feel empathy and sympathy toward someone or something in pain. This empathic connection with the bunny humanizes Trevor as someone who can understand the suffering of another. In addition, compassion is an emotion that is often associated with women and femininity, which would fall in line with her gender performance as "woman." The second emotion, revulsion, could be a biological response to the carnage, knowing that the bunny is still alive in its maimed state. On the other hand, this emotional state could be representative of the gendered notion that women are supposed to be disgusted by blood and gore, which again aligns with a feminine gender performance. The third and final response, fascination, however, is a veering away from Trevor's feminine gender performance. Her fascination undermines her feminine gender performance of

${ }^{61}$ J. Peter Rothe, "Violence Against Nature," in Driven to Kill: Vehicles as Weapons (Alberta, Canada: The University of Alberta Press, 2008), 79.

${ }^{62}$ Rothe, "Introduction," 6. 
compassion because she does not do anything to come to the bunny's aid. Rather than attempt to either assist the bunny or kill the bunny to end its suffering, Trevor exploits its suffering by retrieving her camera and taking photographs of the carnage she has caused. This act of exploitation could be coded as masculine as she is attempting to assert dominance over the bunny and to use its suffering for selfish purposes. Trevor has a "light bulb" moment for her art installation, and then she retrieves her work gloves. At this point in the play, it is unclear whether Trevor is planning to help the animal she has hit or to prolong its suffering. At this point, the zone of relevance for the vehicular violence shifts from immediate to the mediate zone, which means that the vehicle "plays a major role in the facilitation of violence but still falls short of being the blunt instrument." ${ }^{\prime 63}$ There is no resolution on this moment as this is the final stage direction for this transition; however, Trevor's intentions for the bunny will be made clear by the end of the play.

Five months pass in the world of the play between the initial car accident and the first intentional act of vehicular violence. The following moment serves as a transition between a monologue given by FBI Man and the discovery of Frizzy-Haired Man's body, who has died from tularemia after exposure to Trevor's latest art project.

\section{- This Could Be That}

During the following, TREVOR drives home from her studio. She wears special gloves.

She hits several small animals along the way. THUMP. THUMP. THUMP.

Each one she hits she stops and retrieves, with compassion and horror. Some of the animals are still alive.

It is a dance; the Hit Animal Dance.

${ }^{63}$ Ibid. 


$$
\text { It is funny. }{ }^{64}
$$

The title of the scene, "This Could Be That," is one of the lines the Doctor states to the FBI Man when attempting to diagnose the cause of death of Frizzy-Haired Man. Unlike the first car accident, this moment is premeditated violence as Trevor is already wearing the gloves to pick up the animals once she hits them. Because there is premeditation, this event falls less under the category of a roadkill accident and more under vehicular poaching, defined by Rothe as:

Poaching is the illegal hunting, killing, or capturing of animals. Poachers devastate nature by breaking laws that are designed to ensure proper wildlife management and species survival. They kill animals without a licence or permit, use prohibited weapons or technology, shoot animals outside of the designated time of day or year, and kill animals of a prohibited sex or life stage...Poaching is typically a crime of secrecy and stealth, whose full damage is largely unknown...Much of this poaching occurs with the support of motor vehicles. ${ }^{65}$

The targets of Trevor's violence are small animals and rodents, which typically do not require licensure or permits to hunt and kill. However, Trevor is intentionally disrupting the ecosystem of the stretch of road where she is killing the animals because she is killing prey and confiscating it from its natural environment. Trevor is seeking out these small animals on the roadways at night, using the darkness as her cover and her bright headlights to blind them prior to striking them with her vehicle. By driving at night, she also can detect whether any other motorists are around or whether any motorists are coming before she exits the vehicle to claim the injured animal. While she is not using traditional weaponry used in poaching (for example, rifles or crossbows), she is intentionally killing them or maiming them with the assistance of her motor vehicle. This manifestation of vehicular violence and vehicular poaching is not acknowledged as a

${ }^{64}$ Callaghan, "Roadkill Confidential," 124.

${ }^{65}$ Rothe, "Violence Against Nature," 74. 
possibility in Rothe's text, but the methodology does meet the criteria for both. Three of the factors of vehicle violence are clear: Trevor is the person involved in the vehicular violence, the situation is that she is hitting animals with her vehicle, and her vehicle is the primary weapon. Trevor is committing vehicular poaching as she is intentionally striking and killing animals and disrupting the ecosystem in which they exist without a license or permit to do so. These shifts and variations to Rothe's limited definition of vehicular poaching represent the larger disruption at play in terms of gender performance. While Rothe suggests that all the variations of vehicular violence are masculine acts, this act defies his definitions and is performed by a woman, subverting Rothe's narrow scope.

What would potentially cause a person to commit acts of vehicular violence?

Rothe, along with his colleague Linda J. Carroll, argue that the social context is similar to that associated with other kinds of violence:

Some of the most important social and psychological risk factors for vehicular violence are common across other types of violence. These include high levels of economic inequality, cultural norms that condone violence, rigid gender roles, breakdown of community support structures, poor parenting practices and family dysfunction, disenfranchised youth, psychological disorders, alcohol and substance abuse, a history of engaging in violent behaviour, and a history of experiencing abuse (Rothe 2008). These factors also play a role in situations where the motor vehicle is used for violence. ${ }^{66}$

The play omits many of these details from Trevor's backstory. She rose to fame by enlarging photographs of her husband's dead wife following her fatal car accident, which, while in and of itself is not violent behavior, does indicate a fascination with violence and brutality. One risk factor, however, stands out: rigid gender roles. Trevor reacts to each of these killings as she did to the first accident, with "compassion and horror." Trevor has

\footnotetext{
${ }^{66}$ Linda J. Carroll and J. Peter Rothe, "Viewing Vehicular Violence through a Wide Angle Lens: Contributing Factors and a Proposed Framework," Canadian Journal of Criminology and Criminal Justice 56, no. 2 (February 2014): 154.
} 
maintained her feminine gender performance of "compassion" and "horror" to the maimed animals but has disrupted cohesive feminine gender performance by first deciding to exploit the animals' suffering for her work and then taking that objective further by intentionally hunting down and killing more animals with her car. Her affinity for and fascination with violent behavior and brutality is coded as masculine rather than feminine in gender performance.

In the time that has passed from the first incident to the second, Trevor has lost the reaction of "revulsion." This could indicate that Trevor is more mentally prepared for the destruction, blood, and gore that she will be encountering and is in the very early stages of desensitization to the act she is committing. Lack of emotion is often coded as masculine, so this could be another subversion of Trevor's gender performance. This desensitization could also be manifesting in the fact that this becomes a "dance," specifically, the "Hit Animal Dance." The repetition of these actions makes this "dance" a ritual of sorts; she cannot create her art without performing the specific ritual of striking the animals with her vehicle and then retrieving the animals for later use. The violence has become a brutality "machine," and its clinical nature could cause this moment to appear to be a more masculine iteration of Trevor's gender performance. Callaghan indicates that this ritual vehicular poaching should be "funny;" the source of this comedy could be from the juxtaposition of Trevor intentionally hitting the animals with her car and then immediately dealing with the horrific consequences of her actions, especially if some of the animals she strikes are still alive when she retrieves them. This note from Callaghan could indicate that the violence and brutality that Trevor is enacting should not trigger alarm or fear in an audience, but the humor may derive from a tinge of ineptitude 
that is coded as feminine for the purposes of making this act of violence "funny." Women are not expected to be violent. Women are not supposed to be funny either; using humor and absurdity to present violence by women allows the audience to consider the possibility that contrary to popular narratives, women can be just as violent, and just as funny, as men.

The tone and intentionality of Trevor's violence continues to shift over each Hit Animal Dance. The interlude cited below occurs roughly halfway through the play after FBI Man has revealed to the audience how Trevor's art installation Impact changed the trajectory of her stepson Randy's life:

\section{- Interlude: Trevor Drives from Her Studio}

TREVOR drives from her studio.

She hits several small animals along the way. THUMP. THUMP. THUMP.

Each one she hits she stops and retrieves. But the dance is different this time. Not as funny.

Meanwhile, the FBI MAN cannot sleep. He turns the surveillance camera on once again, and watches. ${ }^{67}$

Even though this interlude is nearly identical to the previous Hit Animal Dance, some information in this interlude indicates that Trevor has changed since the last Hit Animal Dance the audience has seen. ${ }^{68}$ This dance is "not as funny," but Callaghan has left it up to interpretation as to how it is not as funny. In addition, there are no emotions associated with Trevor's behavior at all. This could be an indication of Trevor's desensitization to the ritual acts of vehicular poaching, which are continuing to affect her less and less each

${ }^{67}$ Callaghan, "Roadkill Confidential," 175.

${ }^{68}$ A point of clarification is required with this interlude as the name of the interlude and the first stage direction indicate that Trevor is repeating previous action and driving from her studio to her home, but the line that FBI Man delivers immediately before this interlude is "Jumpcut. Two nights later. Trevor is driving to her studio." This is likely a simple typo in the anthology. 
time she commits them. Her lack of emotionality may be coded as masculine, and she continues to perform more masculine acts as the play continues. This results in the loss of her emotions and the loss of humor in performing the Hit Animal Dance.

This "Hit Animal Dance" interlude is the first in which Trevor is being watched by the FBI Man as she performs her "Dance." Callaghan has added a spectator, and not just any spectator, but a hypermasculine spectator who is specifically seeking to stop Trevor's project. Trevor is being placed under the male gaze. Feminist film theorist Laura Mulvey, who is credited with coining the term in her essay "Visual Pleasure in Narrative Cinema," argues that in film, all women are looked at, whereas men are the ones doing the looking:

In a world ordered by sexual imbalance pleasure in looking has been split between active/male and passive/female. The determining male gaze projects its phantasy on to the female figure which is styled accordingly. In their traditional exhibitionist role women are simultaneously looked at and displayed, with their appearance coded for strong visual and erotic impact so that they can be said to connote to-be-looked-at-ness. ${ }^{69}$

Even though this play is about Trevor, she is being removed from her own narrative by the constant gaze and surveillance of FBI Man. Even though she is active in committing acts of violence and brutality, the audience is told of her exploits by FBI Man and then see recreations of them as "flashbacks," making her actions passive rather than active. In fact, FBI Man is the first character the audience is introduced to in the play and is the one who introduces the audience to Trevor. Trevor is committing acts of creation and destruction, and yet her story is filtered and mediated for the audience through FBI man's gaze. As Trevor's power is diffused, this creates ambiguity in her performance of

${ }^{69}$ Mulvey, "Visual Pleasure and Narrative Cinema," 837. 
aggression and violence. The behavior of FBI Man, especially while using his gaze, falls

in line with most film noir as discussed by Mulvey:

Ultimately, the meaning of woman is sexual difference...Thus the woman as icon, displayed for the gaze and enjoyment of men, the active controllers of the look, always threatens to evoke the anxiety it originally signified. The male unconscious has two avenues of escape from this castration anxiety: preoccupation with the re-enactment of the original trauma (investigating the woman, demystifying her mystery), counterbalanced by the devaluation, punishment, or saving of the guilty object (an avenue typified by the concerns of the film noir), or else complete disavowal of castration by the substitution of a fetish object or turning the represented figure itself into a fetish so that it becomes reassuring rather than dangerous. ${ }^{70}$

FBI Man repeatedly states how convinced he is of Trevor's guilt in an attempted bioterrorist plot; there is no other option for FBI Man. To prove his conviction, he takes on the task of investigating her for the FBI. He then devalues Trevor by making several disparaging comments throughout the piece about her. For example, he refers to her as "nuts,"71 “total sociopath,,72 "insane,"73 "mean,"74 and "a dopehead, a thief, a terrorist AND a liar." ${ }^{75}$ It is his only source of power over the narrative of the play. All these behaviors are coded as highly masculine-reliving trauma, devaluing the guilty woman, and fetishizing Trevor through voyeurism. Art critic John Berger comments on the nature of this male spectatorship in his text Ways of Seeing:

A man's presence is dependent upon the promise of power which he embodies. If the promise is large and credible his presence is striking. If it is small or incredible, he is found to have little presence. The promised power may be moral, physical, temperamental, economic, social, sexual — but its object is always exterior to the man. A man's presence suggests what he is capable of doing to you or for you. His presence may be fabricated, in the sense that he pretends to be

\footnotetext{
${ }^{70}$ Ibid., 838.

${ }^{71}$ Callaghan, "Roadkill Confidential," 162.

${ }^{72}$ Ibid., 174.

${ }^{73}$ Ibid.

${ }^{74}$ Ibid., 162.

${ }^{75}$ Ibid., 163.
} 
capable of what he is not. But the pretense is always towards a power which he exercises on others. ${ }^{76}$

By being on the outside of the narrative, FBI Man can maintain control over what happens, what the audience is allowed to know, and in what order the audience is allowed to know it. And yet, Callaghan may have created this icon of masculinity to undermine it. He embodies the male gaze, yet he only has one eye, which weakens the power of his gaze. This absurdist choice by Callaghan adds to the campiness of FBI Man's hypermasculine performance, destabilizing his gender performance. Eventually, when he tries to intervene directly with Trevor's plot, he loses control over the narrative, Trevor, and his own emotions in the process, which further weakens his masculine gender performance.

FBI Man encourages Melanie to pet one of the animals that he knows has likely been infected with the bio-terrorist agent, which has sealed Melanie's fate. He breaks out of the scene in preparation for a dialogue with the audience when the following happens:

\section{- Was That Necessary?}

During the following, TREVOR drives to her studio. She wears special gloves. She hits several small animals along the way. THUMP. THUMP. THUMP. Meanwhile ...

The FBI MAN is doing angry pushups or sit-ups, listening to his iPod. He is very very sweaty, shouting to himself over his tunes. Punishing himself.

Unhinged a bit. ${ }^{77}$

Again, Trevor's emotional state is not described in this interlude. Her lack of emotionality is coded as masculine, whereas FBI Man loses aspects of masculinity in this

\footnotetext{
${ }^{76}$ John Berger, Ways of Seeing (London: The British Broadcasting Corporation and Penguin Books, 1972), 45-46.

${ }^{77}$ Callaghan, "Roadkill Confidential," 201.
} 
moment. He is visibly frustrated and is attempting to purge his emotions by exercising. This dual image is an interesting one; the character who the audience believes to be acting irrationally (Trevor) is cool, calm, methodical, and calculating, whereas the character that has been guiding the audience through the plot (FBI Man) has now disrupted it irrevocably and is lashing out. This moment is highlighted by its upsetting of gender expectations, as Trevor displays a masculine lack of emotion and FBI Man a feminine excess. It seems FBI Man has momentarily stopped his surveillance of Trevor to punish himself for his actions. Trevor seems to be completely desensitized to her actions and is completing a set of tasks that would be horrific to most, but have lost meaning to her. In this exchange of emotional states, the two characters have swapped gender roles.

There is only one instance within Roadkill Confidential during which the audience sees Trevor inflict violence without using her vehicle. Towards the end of the play, when her art installation is near completion, the following occurs:

\section{- What's Missing}

TREVOR appears in her studio, working with a dying animal.

The FBI MAN watches on the monitor.

She is outfitted in a chemical hazard suit. She handles a chemical in a syringe extremely carefully.

Only a few of the pieces are covered in tarps now.

She works and works. She talks to the animal.

\section{TREVOR}

Okay

This is gonna hurt like a motherfucker

Deep breaths

(She injects a chemical into an animal. The animal squirms)

$\mathrm{Shhhh}^{78}$

${ }^{78}$ Ibid., 202-203. 
In this final moment of violence witnessed by the audience, FBI Man watches as well, placing Trevor back under his male gaze. Prior to this moment in the play, Trevor has continued to lose her ability to feel with each instance of violence. In this moment Trevor evokes the classic "mad scientist" identity, which is often coded as masculine. However, the behavior that Trevor presents in this moment is complicated by the shushing of the animal she is injecting. Trevor's actions, talking to an animal she is working with and warning the animal of the pain that it will receive, demonstrate that Trevor's empathy has not been completely erased. While inflicting pain, Trevor also seeks to soothe and comfort. While the audience never conclusively knows what it is that Trevor is injecting into the animal, ${ }^{79}$ she is aware that the injection itself will cause more pain to the animal and chooses to acknowledge it. This moment of the play is a collision of gender expectations - while Trevor is inflicting pain (masculine), she is also attempting to comfort (feminine). In this moment, Trevor performs gender ambiguity by regaining some semblance of empathy.

\section{Conclusion}

Callaghan has created several characters that critique gender norms, subvert gender expectations, and highlight gender as performance. Through this play, Callaghan uses her characters to deconstruct media-constructed gender identities such as the film noir detective; the FBI agent; the moody, angsty teenager; the awkward academic; the clueless, cheerful neighbor; the mad scientist; and the aloof visual artist, representations that all call attention to gender as constructed and performed. Trevor Pratt as a character

\footnotetext{
${ }^{79}$ Later on in the play, Trevor asserts to FBI Man that she was injecting painkillers into the animals, but there is no conclusive evidence anywhere else in the script regarding what is actually in the injections.
} 
is constructed to question notions of gender performance from the use of a masculine name, her identity as artist, her desensitization post-trauma, and her violent behavior. In Trevor's attempt to awaken society to the brutality it encounters on a daily basis, Trevor has disrupted society's expectation of gender performance by repeatedly enacting violent acts and other behaviors traditionally associated with men, particularly vehicular violence. She works in a male-dominated field as a visual artist, takes a young protégé lover (and immediately disposes of him), and serves as the head of her household. In addition, Callaghan constructs a hypermasculine image of FBI Man who guides the audience through the course of the play through his male gaze. The absurdity of his extreme hypermasculine gender performance, however, causes his masculinity to be queered and collapse over the course of the play, ending in Trevor stripping away his masculinity and reclaiming her power. Randy performs another version of hypermasculinity through aggressive "fight-dancing," hypersexual language, and screaming at the top of his lungs about his "horrible freaky bitch" stepmother, Trevor. ${ }^{80}$ Melanie showcases hyperfemininity through her gardening and baking skills, seeking Trevor's approval of her, and closing the play performing as a woman in a bed of fur singing a song about waiting for her love to join her. Callaghan's strategic use of camp underscores the artifice in traditional gender performance. Roadkill Confidential is a remarkably original play that forces the audience to question not only the nature of brutality, but also the exposure one has to violence daily, and how people behave when fighting for an agenda they believe in while using highly questionable methods to do so. Callaghan raises the question of who gets to tell stories about women and disrupts the

${ }^{80}$ Callaghan, "Roadkill Confidential," 213. 
male gaze with Roadkill Confidential. By weakening FBI Man's male gaze and his performance of hypermasculinity, Trevor is able to reclaim her own story from the male gaze and to undermine his surveillance and spectatorship.

In the final scene of the play, Melanie lies on display with all the roadkill as part of Trevor's installation and sings a song with the animals. Melanie, who herself is dying amidst the dying animals, sings a song about waiting "and there I sit / in my summer gown / a waitin'/ a waitin'/ a waitin'/ for you." ${ }^{81}$ In this final moment, Callaghan mocks the heterosexist romantic dreams and the women who succumb to them. In her final performance of femininity, Melanie has been struck down by American ideals of womanhood and is left to die; she herself has become roadkill.

${ }^{81}$ Ibid., 227. 


\section{CHAPTER THREE}

\section{That Pretty Pretty; Or, the Rape Play: "I want to kill that pretty" Introduction}

I admit that I avoided reading That Pretty Pretty; Or, the Rape Play for quite some time. I did not want to read another story about the victimization of women, and the title of the work indicated that rape would be a dominant topic within the work. When searching for plays to include in this study, I decided to take a look, however, and see whether this play had anything to offer in terms of gender, gender performance, and violence. As I turned page after page, I was shocked at the number of instances of violence that Callaghan included in this script, and I was perplexed by the structure and meaning of the work. The more I re-read the work, the more fascinated I became both as a violence and intimacy designer as well as a feminist scholar.

"I truly wrote [That Pretty Pretty] with abandon, with the sure knowledge that nobody would ever do it...If the material is frightening to me, it's also me on the page, and I'm pointing the finger at myself." Sheila Callaghan's That Pretty Pretty; Or, the Rape Play ${ }^{2}$ presents frightening and horrific material; the play contains murder, necrophilia, objectification of women, extremely offensive tropes about race and identity, and blatant misogyny. That being said, what Callaghan writes comes from her own internalized views that make this offensive, horrific material transfer from her brain to the page to the stage. In pointing the finger at herself, Callaghan unavoidably also points the

\footnotetext{
${ }^{1}$ J.T. Rodgers, "Deep Conditioning: An Interview with the Playwright," American Theatre, April $2009,79$. ${ }^{2}$ From this point, I will refer to the play as That Pretty Pretty unless the full title is used in a quotation as the repeated use of the word "rape" may be triggering to readers. I will also refer to all instances of rape in the play as sexual assault in an attempt to reduce the risk of triggering the reader.
} 
finger at American society writ large, forcing her readers and audiences to confront the disturbing realities portrayed. That Pretty Pretty certainly meets the criteria of a difficultto-perform show: the title is jarring, the play contains significant amounts of gun violence (something that is notoriously difficult to stage as well as potentially difficult to witness), the characters dive headfirst into some of the most controversial issues (abortion, sexual assault, and conflict in the Middle East, to name a few), and the actors have to memorize nearly identical language that is repeated several times throughout the play. In her preface to her first anthology, Callaghan points to other popular works in the 2000s, which she characterizes s as "nasty" and "misogynistic" as a provocation for writing That Pretty Pretty:

That Pretty Pretty; Or, the Rape Play started out as a reaction to the kind of nasty, misogynistic plays that have been adored by the masses for the past decade [the 2000s]. But then it turned into an investigation of why we - meaning I-find this work compelling and repulsive at the same time. It attempts to critique the images while simultaneously trafficking in them. I don't believe it's right to blame the media for our objectification of women and/or the glamorization of heinous acts against them, because on some level we participate by going along for the ride. So this piece comes out of a deep ambivalence for the position we have put ourselves in as a society, with an eye towards its absurdity. ${ }^{3}$

Callaghan's That Pretty Pretty unequivocally portrays misogyny, which is perpetuated by all the characters. Even though Callaghan finds misogynistic works problematic, she wants That Pretty Pretty to help us understand why these repulsive images of murder, sexual assault, and misogyny are simultaneously compelling for the audience. Rather than solely hold the media responsible, Callaghan questions the sociocultural element that American audiences comply with to keep mindlessly trafficking these images rather than to critically engage with them. This complicated, challenging, and absurd play initially

\footnotetext{
${ }^{3}$ Sheila Callaghan, "Preface," in Lascivious Something, Roadkill Confidential, That Pretty Pretty; or, the Rape Play: Three Plays (Berkeley, CA: Soft Skull Press, 2011), xv.
} 
began as an exploration of gender role inversion but grew into a more complex narrative.

As Callaghan states:

I think anybody who grew up in our generation [Gen $\mathrm{X}]$ has a complicated idea of females in media. We're aware people, but we're also fed on a steady diet of objectification. We're turned on by the sexiness of it, but we also sort of hate that part of ourselves that is turned on by it. We suffer from not saying anything about it. When I first set out to write the play, I was going to write about these two girls. I was trying to invert the tropes that were out there, the imagery. A lot of the plays I'd seen recently were infuriating me - and so also exciting me. I figured I would try to see what it felt like to write those things with the genders flipped. That was an interesting experience, but it didn't get me very far. There was something more specific and pointed that I wanted to talk about that wouldn't be covered by a simple inversion. ${ }^{4}$

Objectification is at the core of That Pretty Pretty; Owen, the protagonist, is a screenwriter who objectifies women in every draft of his screenplay, but he is self-aware enough to question why he creates the characters the way that he does. In some ways Owen embodies the infamous "male gaze," but this play troubles even that still-prevalent trope, presenting myriad forms of objectification of both men and women, compelling audiences to confront and to question our acceptance of these narratives and to reflect upon how these narratives are generated from a misogynist American culture. Originally produced at Rattlestick Playwrights Theatre in February 2009, That Pretty Pretty portrays gender disruption at every turn; men dress as women, women sexually violate men, both genders commit acts of physical violence, and a character named Jane Fonda constantly disrupts any semblance of narrative through enacting physical exercise or servitude.

Of the plays addressed in this study, That Pretty Pretty is the only work to have received scholarly attention: Kelda Lynn Jordan's Masters thesis “Perspectives on Women and Aggression Illustrated through Caryl Churchill's Top Girls, Maria Irene

\footnotetext{
${ }^{4}$ Rodgers, "Deep Conditioning: An Interview with the Playwright," 78.
} 
Fornes's Fefu and Her Friends, and Sheila Callaghan's That Pretty Pretty; Or, the Rape Play" and Jennifer Ann Goff's dissertation “'If More Women Knew More Jokes...': The Comic Dramaturgy of Sarah Ruhl and Sheila Callaghan."5 Jordan's thesis examines That Pretty Pretty through the gender polarity model (the assumption that whatever men are, women are the opposite and vice versa) and suggests that because the gender roles of the characters are reversed, Callaghan's play is representative of the war between the genders. She argues that Callaghan, using Owen as her voice at the end of the play, reveals that women can be just as aggressive as men and that a war between the genders is ever-present, a war which society refuses to acknowledge. ${ }^{6}$ My study extends and deepens Jordan's analysis, particularly in its more thorough investigation of enactments of violence, but also giving more attention to other dramaturgical choices of setting, context, and characterizations. Goff's dissertation investigates the function of comedy in That Pretty Pretty through the lens of Benign Violation Theory, which posits that humor will be generated through a violation of what "should" happen as long as the violation seems benign. ${ }^{7}$ Goff concludes that "The idea that these acts of degradation could ever be made benign is...the real violation that Callaghan is satirizing." ${ }^{8}$ Goff's exploration of the use of comedy in Callaghan's works does not specifically investigate how the humor in the play may be gendered..

\footnotetext{
5 Jordan, "Perspectives on Women and Aggression Illustrated Through Caryl Churchill's Top Girls, Maria Irene Fornes' Fefu and Her Friends, and Sheila Callaghan's That Pretty Pretty; or, The Rape Play"; Goff, “'if More Women Knew More Jokes...': The Comic Dramaturgy of Sarah Ruhl And Sheila Callaghan."

${ }^{6}$ Jordan, "Perspectives on Women and Aggression Illustrated Through Caryl Churchill's Top Girls, Maria Irene Fornes' Fefu and Her Friends, and Sheila Callaghan's That Pretty Pretty; or, The Rape Play," 59-76.

${ }^{7}$ Goff, “'if More Women Knew More Jokes...': The Comic Dramaturgy of Sarah Ruhl And Sheila Callaghan," 77.

${ }^{8}$ Ibid., 91.
} 
In this chapter, I will investigate how the varying types of violence performed in That Pretty Pretty (violence with weapons, physical violence, and sexual violence) interplay with what Callaghan has referred to as the "celebratory fractiousness" of her characters' gender performances.

\section{Structure and Style of That Pretty Pretty; Or, the Rape Play}

Among the most important elements to address to increase understanding of That Pretty Pretty are its overarching structure and tone. One of the major components of the work is its metatheatricality. Callaghan indicates that the first several scenes feel "very fake...perhaps the set is too vivid, perhaps everyone is a little too enthusiastic. The acting in the following seen [sic] should be completely and artificially over-the-top intense. Lots of volume." Absurdism is the modus operandi for most of the play. All the scenes feel too loud, too outlandish, and too vivid; at some points, Callaghan indicates in the stage directions that the characters act as though they are in a bad Harold Pinter play. That Pretty Pretty constantly calls attention to itself as both satirizing the writing and revision process as well as the celebration of works that are blatantly misogynistic.

It is not until 45 pages into the script that the reader discovers all this overdone absurdity has been a fantasy. It is at this point that Callaghan indicates "Unlike the previous hotel scenes, this room feels authentic and hyperreal. The acting is naturalized." 10 In this hotel scene between Owen and his buddy Rodney, the reader discovers that all of the previous scenes are attempted drafts of a screenplay Owen has

\footnotetext{
${ }^{9}$ Sheila Callaghan, "That Pretty Pretty; Or, the Rape Play," in Lascivious Something, Roadkill Confidential, That Pretty Pretty; Or, the Rape Play: Three Plays (Berkeley, CA: Soft Skull Press, 2011), 235.

${ }^{10}$ Ibid., 278.
} 
been working on. Like Roadkill Confidential, the entire play of That Pretty Pretty is told from the perspective of a male narrator, in this case, Owen. Callaghan comments on the male gaze of the piece:

Whenever I start talking about the male gaze, it turns into a conversation about the polemics of the piece. That's in there; it's embedded in the play. But I think the play is more fun than that. There's a celebratory fractiousness in the tone, and joy within the anger. ${ }^{11}$

Some of this "joy within the anger" manifests in the dialogue of other characters, who are enacting what Owen has written. In the first draft of his "hotel scene" with his characters Agnes and Valerie, these moments manifest when Owen has seemingly lost his place in the story and by default leans heavily into female tropes to further the plot:

VALERIE

And no one heard you over the Quiet Riot. And you could have slipped and fallen, like that time on your garage door.

They stare at each other a moment. Something subtle changes in VALERIE.

She opens her computer and begins to type furiously. AGNES does not hear her speak.

VALERIE (cont.)

Words words words. Come on, sucka. This gal is a real beeyotch. BITCH SUPREME. Talkin' shit about her manifesto... ridding the world of shitbags trying to jam their laws into her uterus...Lots of fucks. Fuck fuck fuck. What else...OH! She's a secret dyke! HA, YES!!! Wants to get her freak on with Agnes! But wait, they're sisters. Think on this, come back to it later. Maybe she should be more angry, or like. Oh, and super hot. A super hot angry dyke. She's a HATER. RAAAR! YEAH!! LIKE AN ANIMAL!!! ${ }^{12}$

As Valerie types into her computer, she says aloud what Owen is thinking or navigating through while writing his script. While the words and actions of the character are Owen's, the reader sees them displaced through Valerie's body and voice. Valerie's

\footnotetext{
${ }^{11}$ Rodgers, "Deep Conditioning: An Interview with the Playwright," 78.

12 Callaghan, "That Pretty Pretty; Or, the Rape Play," 242.
} 
"character" is writing a feminist manifesto as well, but the words she states are character development that Owen is attempting to create. After typing this paragraph, Valerie embodies the character Owen has described by speaking in short, caveman-like all-caps phrases such as "DIET COKE!" "VENDING MACHINE!” and "IF THEY DON'T HAVE?" to communicate a profound change within the personality of Valerie's character from a calmer demeanor to the "super hot angry dyke." 13

Like Roadkill Confidential, Camp and satire run rampant throughout That Pretty Pretty. All the characters carry "sincere" performances of gender to extreme lengths, underscoring the "artifice" that is essential to Camp sensibility. ${ }^{14}$ The Camp humor in this work highlights the extremes of gender stereotyping and adds to the "celebratory fractiousness" that Callaghan weaves into the work.

Reality does not come back into the world of the play until the final four pages of the script (Callaghan's), where Owen comes out for a "talk-back" with the audience after the screening of his film. The characters Jane, Rodney, and Owen are seen in two different contexts: the fantasy world of Owen's screenplay drafts and the "real" world of the play. For the sake of simplicity, I will be referring to these characters as "fantasy Rodney/Owen/Jane" and "reality Rodney/Owen/Jane.” Agnes and Valerie are always shown in the play as fantasy even though Agnes is based on a real person that Owen had a relationship with, so they will be referred to only as Agnes and Valerie.

\section{Character Gender Disruption: Agnes}

\footnotetext{
${ }^{13}$ Ibid., 242-243.

${ }^{14}$ Sontag, "Notes on Camp," 312.
} 
In the dramatis personae of That Pretty Pretty, Agnes is described as "female, trashy, sexy, disarmingly angelic." ${ }^{\prime 15}$ The name Agnes is derived from Greek meaning "chaste," 16 making the last descriptor of Agnes in the dramatis personae all the more fitting and confounding simultaneously, as she is a former stripper who, at one point in the play, states "I'm the ho here. Just remember that." ${ }^{\text {"17 }}$ For the purposes of Owen's screenplay, Agnes represents the femme fatale. French for "fatal woman," the femme fatale trope is defined in the Oxford English Dictionary as "An attractive and seductive woman, esp. one who is likely to cause risk to or the downfall of anyone who becomes involved with her." ${ }^{18}$ Historian Kirsten Smith further defines aspects of the femme fatale in her article "Seduction and Sex: The Changing Allure of the Femme Fatale in Fact and Fiction:"

The femme is identified by the power she has over men and how she uses this for her own benefit. She is expected to present some obstacle to the hero and to deceive and to betray him... She challenges the hero because she disrupts the normal gender roles with a range of deviant behaviours. These behaviours can include clear independence from men, a free and unapologetic sexuality, or it can come from her involvement with the villain or 'other' side, placing her in direct conflict with the hero's mission. One of the key things that sets her apart from other enemies, and what allows her to be an alluring danger to the hero, is the fact that she often does not appear at first to be dangerous. Instead the femme uses her femininity to entice the hero into betrayal by exploiting him in the vulnerable and intimate area of sex. ${ }^{19}$

There is no question that Agnes enacts many deviant behaviors throughout the play. In the first version of Owen's screenplay, Agnes is the one who sets up Rodney to be killed by Valerie and "humps" his corpse's leg until she climaxes. In the second version of

\footnotetext{
${ }^{15}$ Callaghan, "That Pretty Pretty; Or, the Rape Play," 232.

16 "Meaning, Origin and History of the Name Agnes - Behind the Name," accessed March 24, 2019, https://www.behindthename.com/name/agnes.

${ }^{17}$ Callaghan, "That Pretty Pretty; Or, the Rape Play," 236.

18 "Femme Fatale, n.," OED Online (Oxford University Press, n.d.), accessed April 28, 2019, http://www.oed.com.proxy.mul.missouri.edu/view/Entry/291008.

${ }^{19}$ Smith, "Seduction and Sex: The Changing Allure of the Femme Fatale in Fact and Fiction.," 37-38.
} 
Owen's screenplay, Agnes is the victim of Rodney and Owen's seduction; she is tied up by Rodney with whom she engages in sadomasochist play, including Rodney extinguishing cigarettes on her and shocking her. In each of the versions of Owen's screenplay, Agnes is portrayed as an unapologetically sexual woman who uses her sexuality to get her way. Agnes is also the former significant other of Reality Owen, but only the fantasy version of her appears in the play; by constructing Agnes as a femme fatale, Reality Owen is directly blaming Agnes for his apparent downfall in his selfesteem, his relationships with others, and his inability to write the screenplay he wants to write.

In one of the slips into Owen's reality, the audience discovers that it is Agnes who is the abusive partner in their relationship dynamic. Agnes physically abuses Owen by hitting him (in a blackout, so the audience does not see this act) and threatening him with a cocked gun, and verbally abuses Owen by calling him a "faggot," "gaywad," "Turd licker," and "ass muncher." 20 According to the National Domestic Violence Hotline, 1 in 4 women $(24.3 \%)$ and 1 in 7 men $(13.8 \%)$ aged 18 and older in the United States have been the victim of severe physical violence by an intimate partner in their lifetime... Nearly half of all women and men in the United States have experienced psychological aggression by an intimate partner in their lifetime. ${ }^{21}$

Although women are much more likely to experience intimate partner violence than men, some women are also abusive towards men. By making Agnes an abusive partner, Callaghan forces the reader to contemplate several aspects of Agnes' character all at once. In previous scenes, she has enjoyed sadomasochist play with Fantasy Rodney and Fantasy Owen. In Owen's version of the screenplay, Agnes is a sexual and gender

\footnotetext{
${ }^{20}$ Callaghan, "That Pretty Pretty; Or, the Rape Play," 261-263.

21 "Statistics," The National Domestic Violence Hotline, accessed March 28, 2019, https://www.thehotline.org/resources/statistics/.
} 
deviant who enjoys sadomasochist play and necrophilia, which is a grotesque spin Owen makes to Agnes' real abusive tendencies. This creates the "celebratory fractiousness" that Callaghan has described for the reader and the audience as to who Agnes really is, destabilizing her gender performance. After this point, Agnes' role becomes diminished over the course of the play as Owen's story becomes more central to the narrative.

\section{Character Gender Disruption: Valerie}

In the dramatis personae, Valerie is described as "female, bullish, tough, crazy sexy."22 While Callaghan identifies Valerie as "female," she also redefines what femaleness means for Valerie's characterization by describing her as “bullish, tough, [and] crazy sexy." From this character description, Valerie also evokes some aspects of the femme fatale by being "crazy sexy," but this is contradicted with her "bullish, tough" (also "deviant" but suggesting "mannish") behavior that Owen writes into her character.

The name Valerie derives from French and Roman roots, meaning "strong, healthy,"23 which matches the tough and bullish personality Owen conjures in her. Valerie's character functions as a foil to Agnes in Owen's fantasy and as a correlate to "reality" Owen. Her actions seem colder and harsher than Agnes' actions; for example, Valerie is the one who shoots Rodney in the hotel room and then documents it by taking photographs and posting it on the blog. Rather than being the "bait," Valerie chooses to be the "assassin," which evokes a more masculine gender performance. Valerie is also the one who ends up victorious in the Jell-O wrestling match/pillow fight and does not return to the play until the final product film scene. This moment will be discussed later

${ }^{22}$ Callaghan, "That Pretty Pretty; Or, the Rape Play," 232.

23 "Valerie Name Meaning \& Origin," Baby Name Wizard, accessed March 24, 2019, http://www.babynamewizard.com/baby-name/girl/valerie. 
in the chapter in more detail, but Valerie's gender performance is more masculine than Agnes' as she bests her in a sportsmanlike competition that quickly shifts into an assault on Agnes. In the final version of Owen's film, Valerie is sexually assaulted, but does not cry. In this scene, Owen repeatedly comments on how "dignified and heroic" 24 Valerie is. This behavior corresponds to the etymology of her name as she is being valiant and strong in the face of her pain and suffering. Women often conceal their pain in fear that performing pain or emotions will make them appear "weak," which would reinforce the feminine gender performance of Valerie. ${ }^{25}$ As she attempts to hide her pain, Valerie negates the ability to perform fully feminine and "weak," keeping in line with her name.

\section{Character Gender Disruption: Rodney}

In the dramatis personae, Rodney is described as "male, fit, charismatic, chill and yet oddly dangerous." 26 The name Rodney derives from an Old English name "Hroda" which means "famous" or "renowned" and Old English "eg" meaning "island," therefore making the name Rodney translate roughly to "famous island." 27 This name does not seem to have much relevance in terms of gendered associations, but Rodney later refers to himself in the third person as "The Rod," an explicit phallic connotation. ${ }^{28}$ Reality Rodney is visiting his good friend Reality Owen while Reality Rodney is on leave from the military.

\footnotetext{
${ }^{24}$ Callaghan, "That Pretty Pretty; Or, the Rape Play," 311.

25 "Why We Hide Emotional Pain | Psychology Today," accessed March 28, 2019, https://www.psychologytoday.com/us/blog/evolution-the-self/201109/why-we-hide-emotional-pain. ${ }^{26}$ Callaghan, "That Pretty Pretty; Or, the Rape Play," 232.

27 "Rodney Name Meaning \& Rodney Family History at Ancestry.Com,” accessed March 24, 2019, https://www.ancestry.com/name-origin?surname=rodney.

${ }^{28}$ Callaghan, "That Pretty Pretty; Or, the Rape Play," 288.
} 
Rodney is a central figure in several of the drafts of Owen's scripts and is often fantasized about in a hypermasculine way by Owen. In the first draft of Owen's screenplay, Fantasy Rodney is objectified by Agnes and Valerie in several different ways. First, he is a victim of Agnes' and Valerie's crime spree; then, he becomes a sexual object of Agnes, who grinds against him for her own sexual satisfaction; finally, he becomes a puppet manipulated by Agnes who ventriloquizes Rodney saying anti-abortion and pro-Christian rhetoric. Rodney has no agency in this draft of the screenplay, which could be emblematic of how Owen feels about his relationships with women. Rodney is a plaything both for sexual gratification and a puppet repeating conservative and misogynist views. In the second draft of Owen's screenplay, Fantasy Rodney enacts the sadomasochist play on Agnes with hints at Reality Rodney's military background. This masculine performance of dominance and control over a woman could represent what Owen thinks is masculine and desirable for a man to do to a woman. In the third version of Owen's screenplay, Fantasy Rodney is a dignified gentleman who is leading the dinner party. A debonair James Bond-esque charmer, he smokes cigars and throws money at the women while they wrestle in the Jell-O; for this Rodney, money is no object and he can buy whatever kind of company he desires. As representative of Owen's fantasy, this version of Rodney exudes confidence and can have his choice of whatever he wants because of his wealth and charm.

Rodney's identity as a soldier is a significant one for understanding gendered aspects of his character. Fantasy Rodney tells a long story related to his time in "THE war" during the dinner party scene, which highlights the barbarism of the country he and his squadron invaded. In the graphic story, Rodney describes the enemy as "poop- 
flingers" that were then burned to death by his squadron using flamethrowers. Both Fantasy and Reality Rodney are proud of this story of conquering the "poop-flingers." Social work researchers John Fox and Bob Pease have investigated the interconnected nature of masculinity, military, and military trauma:

Both traditional ideas of masculinity and femininity involve expectations of appropriate conduct in relation to the threat or experience of violence and form key parts of the "environment." Men are expected to be competent in violence and able to stoically and rationally respond to it. Indeed, masculine standards place a high value on risk-seeking behaviour, deliberately facing risk and successfully dominating it (Levant,1996). They constitute rites of passage to manhood. Whilst evading or failing to dominate it are often treated as failures of manhood. ${ }^{29}$

Rodney describes enacting risk-seeking behavior by using flamethrowers to kill their enemy, but his squadron's tactic to use flamethrowers to kill does not seem at all rational. Rodney's description of the enemy as "poop-flingers" codes highly xenophobic.

Sociologist Michael S. Kimmel discusses masculinity as a homosocial and highly competitive performance: "Masculinity is a homosocial enactment. We test ourselves, perform heroic feats, take enormous risks, all because we want other men to grant us our manhood. Masculinity as a homosocial enactment is fraught with danger, with the risk of failure, and with intense relentless competition." 30 Rodney stresses the xenophobic and masculine elements of the torture of the enemy to gain approval from Owen as the only other male dinner guest.

With Rodney's character, Callaghan overtly evokes and critiques a brutal heteromasculinist militarism. This war story is not the only war story that Owen incorporates into the plot. Reality Rodney suggests that Reality Owen include a story that

\footnotetext{
${ }^{29}$ Fox and Pease, "Military Deployment, Masculinity and Trauma: Reviewing the Connections.," 24-25.

${ }^{30} \mathrm{Kimmel}$, The Gender of Desire: Essays on Male Sexuality, 33.
} 
Rodney has previously told him about placing a grenade in a 13-year-old girl's vagina and pulling the pin. This act of brutality evokes images of the My Lai Massacre, in which the Charlie Company of the American Division's 11th Infantry Brigade slaughtered, used grenades on, raped, and mutilated an entire village; most of the atrocities were committed on women and children. ${ }^{31}$ The last time Rodney appears on stage, it is as Fantasy Rodney, who shoots Jane Fonda, Agnes, and Valerie execution style, repeating this imagery. This militaristic masculine performance from Rodney could be compensation for military trauma, as he was one of the perpetrators against the child. As Fox and Pease discovered:

The veterans' experience of military training had heightened this sense of masculinity. In particular, it had given them a sense of invincibility and indestructibility. However, their experience of combat had not matched this identity. The veterans experienced helplessness, confusion, horror, disorientation and fragility in the face of the uncertainty and extremity of combat, rather than the anticipated calm, confident, successful implementation of their training. They also had contradictory experiences of power and pleasure in violence (Karner, 1994). Finally, they also confronted women and children as enemies, contrary to their expectations of protecting them from other men. It was the combination of these contradictions of vulnerability and moral ambiguity that produced a rupture in the veterans' sense of self. It was this experience of the failure to conform to their understanding of masculinity - with its demands that they master potentially overwhelming personal threats as well as protect the weak and innocent (which women and children were expected to be) - that constituted the veterans' trauma, rather than the traumatic events themselves. ${ }^{32}$

The incongruity of what Rodney was promised-masculinity, invincibility, and indestructability — with the reality of what he was asked to do — sexually assault and mutilate a 13-year-old — creates fractiousness for Rodney's gender performance. He does

${ }^{31}$ Editors, "My Lai Massacre," HISTORY, accessed April 28, 2019, https://www.history.com/topics/vietnam-war/my-lai-massacre-1.

${ }^{32}$ Fox and Pease, "Military Deployment, Masculinity and Trauma: Reviewing the Connections.," 26. 
not have solid footing in how to deal with his trauma, so he asks Owen to write the trauma for him.

At one point in the play, Fantasy Rodney transforms into a "rocker" Fantasy Rodney "in rocker tights, big hair, and eyeliner. He is pure rock and roll." 33 Lip-syncing to "Still of the Night" by Whitesnake, Fantasy Rodney seduces Fantasy Owen (who is wearing a dress and makeup), then abandons the stage once Fantasy Owen goes into labor. This is a transgressive performance of masculinity which is more akin to the David Bowie glam rocker gender-bending androgyny. This representation of Rodney is another one of Owen's fantasy explorations of the varying forms of masculinity, even if on the surface it may appear feminine in gender performance. Kimmel argues that the varying forms of hegemonic manhood and masculinity boil down to one main equation:

The hegemonic definition of manhood is a man in power, a man with power, and a man of power. We equate manhood with being strong, successful, capable, reliable, in control. The very definitions of manhood we have developed in our culture maintain the power that some men have over other men and that men have over women. ${ }^{34}$

Even though Rodney is superficially feminine or androgynous in his performance by wearing tights and eyeliner, Rodney is still asserting power over Owen. While this may be a demonstration of manhood by Rodney's maintaining power over Owen, it may also be a manifestation of the way women use sexuality to exert power over men in a heteronormative culture, rendering Rodney's gender performance semiotically unstable.

\section{Character Gender Disruption: Owen}

${ }^{33}$ Callaghan, "That Pretty Pretty; Or, the Rape Play," 274.

${ }^{34} \mathrm{Kimmel}$, The Gender of Desire: Essays on Male Sexuality, 30. 
The meaning of the name of Owen is disputed; some sources claim that it is the Welsh derivative of the name "Eugene," meaning "well-born, noble," 35 whereas other sources identify its origin as Irish, meaning "born of the yew tree." ${ }^{36}$ It is this second interpretation that holds considerable meaning, as the yew tree has been called the "death tree" and symbolizes death and resurrection for many European cultures. ${ }^{37}$ As Owen is the one creating and destroying the narrative for the audience at every turn, it seems fitting that this character's name is aligned with death and resurrection.

In the dramatis personae, Owen is described as "male, sensitive hipster-ish dude," ${ }^{38}$ which could imply that he is not as inherently masculine as Rodney but is also another example of Callaghan redefining gender norms, as she did in her character description of Valerie, associating "female" with "bullish, tough, crazy sexy." Here she equates sensitivity with "male." Owen is a writer, specifically, a screenwriter, which is an industry dominated by men. According to Martha M. Lauzen's “The Celluloid Ceiling: Behind-the-Scenes Employment of Women on the Top 100, 250, and 500 Films of 2017 ," out of the 250 top grossing domestic films, only $11 \%$ had women writers attached to the project. The film industry has been notoriously male-dominated and repeatedly produces masculine narratives and tropes, often creating hyper-masculine images of men committing acts of violence by turning them into superheroes, adventurers, or spies. Black Panther, Avengers: Infinity War, Jurassic World: Fallen Kingdom, Deadpool 2,

\footnotetext{
35 “Owen Name Meaning \& Origin,” Baby Name Wizard, accessed March 24, 2019, http://www.babynamewizard.com/baby-name/boy/owen.

${ }^{36}$ Mike Campbell, "Meaning, Origin and History of the Name Eoghan," Behind the Name, accessed March 24, 2019, https://www.behindthename.com/name/eoghan.

37 "Mythology and Folklore of Yew | Trees for Life," accessed March 26, 2019, https://treesforlife.org.uk/forest/mythology-folklore/yew/.

${ }^{38}$ Callaghan, "That Pretty Pretty; Or, the Rape Play," 232.
} 
Aquaman, Jumanji: Welcome to the Jungle, Mission Impossible: Fallout, and Ant-Man and the Wasp all featured in the top 10 highest grossing films of $2018,{ }^{39}$ reinforcing the popularity of hypermasculinity.

Owen inserts himself into his own gaze by creating a Fantasy Owen who engages in the drafts of the plot with the other characters. Fantasy Owen first appears in the second draft of the screenplay, where he takes on the role of the more assertive, cool, incontrol man in the hotel scene. In this version of the hotel scene, a brutal performance of misogyny, Fantasy Owen shoots Agnes in the head, then hacks her body with a machete and a sledgehammer, which could be representative of the amount of anger Reality Owen holds towards Agnes. Fantasy Owen falls to the wayside as Reality Owen begins to take over the Fantasy Owen persona, communicating the real anger that Reality Owen has towards Agnes:

\section{OWEN}

Lies and bullshit, every word. 'I love you, Owen.' Bullshit. 'I've loved you since the day you screamed at me about the garage door.' Bullshit. Look at her. SLUT SUPREME. Had more cock than a poultry farm. She can't play the piano worth shit. She has no class. She won't shut the fuck up. She's a cancer. She takes over your mind. You wanna tear your eyeballs out and feed them to the cat! ${ }^{40}$

In this monologue, Owen becomes highly aggressive and misogynistic. Here, Owen is compensating for the hit to his ego of having lost Agnes, compensation that manifests in the form of an over-done performance of masculinity, the sort of behavior that Kimmel attributes to a profound lack of self-worth: "That nightmare from which we never seem to awaken is that those other men will see that sense of inadequacy; they will see that in our

\footnotetext{
39 “The Numbers - Top-Grossing Movies of 2018," accessed March 26, 2019, https://www.thenumbers.com/market/2018/top-grossing-movies.

${ }^{40}$ Callaghan, "That Pretty Pretty; Or, the Rape Play," 259.
} 
own eyes we are not who we are pretending to be. What we call masculinity is often a hedge against being revealed as a fraud, an exaggerated set of activities that keep others from seeing through us, and a frenzied effort to keep at bay those fears within ourselves. ${ }^{41}$ It is at this moment that Owen's screenplay is again interrupted by Jane Fonda, who functions as another one of his muses while screenwriting. She cautions him against this masculine performance and then reassures him that he can still write, so Owen re-centers himself, both in attitude and gender performance, and tries again.

At one point in the play, Reality Owen begins to alter his gender performance. He dons a gown provided to him by Jane Fonda and begins to apply makeup as he tries to immerse himself into the mind of Agnes' character that he is manufacturing:

\section{OWEN (cont.)}

I am so fucking pretty. I am so fucking fucking pretty, yo. Suckas. You wanna suck lemons from my cheeks. I got fuckin' mad pretty on my shit. My pretty is like PROFOUND. It has emissions. Waves of pretty. I'm like a gas burner of pretty. Stick a pot on me and I'll make it whistle. Step the fuck off, right, 'cause my pretty will eat your soul. My pretty is a black hole. I am so pretty I drain all the ugly off you and wear it like a swimsuit. GODDAMN AM I PRETTY. Holy fucking shit. You can't stand it. You are like, "She is so pretty I need to BASH her. I need to tear her pubes out. I need to hate on her. That pretty is cancerous. That pretty is a little iced cookie and I need to bite it. That pretty is TOXIC. That pretty boils in my gut, it eats me up, that pretty comes to me at night and scrapes all my tender spots. Soils my boxer briefs. That pretty is FUCKED UP, I need to poke through it with my thumbs, I need to fuck the joy out of that pretty. I want to kill that pretty. I want to kill that pretty. I want to kill that pretty."

That's what they say about me. ${ }^{42}$

Over the course of this monologue, Owen shifts pronouns. He goes from discussing what he thinks of himself, then discusses what others will say about him, but instead of using he/him pronouns, he uses she/her pronouns. At the end of the monologue, Owen

\footnotetext{
${ }^{41}$ Kimmel, The Gender of Desire: Essays on Male Sexuality, 30.
}

${ }^{42}$ Callaghan, "That Pretty Pretty; Or, the Rape Play," 274. 
reinforces that the third person she/her referenced is indeed Owen. In addition, Owen uses the word "pretty" to describe his appearance twenty-one times. In the Oxford English Dictionary, "pretty" is defined as "Of a person, esp. a woman or child: attractive and pleasing in appearance; good-looking, esp. in a delicate or diminutive way." ${ }^{23}$ This definition associates "pretty" with delicacy, which is a highly feminine (and even girlish) way to describe the beauty of another human being. Men are rarely associated with delicacy, and being referred to in a diminutive way might be read as belittling to a man's masculinity. The fact that Owen craves and desires to be considered "pretty" directly contradicts what societal expectations are for him as a man. By Callaghan inserting this word choice twenty-one times and using it as the title of the play, she is commenting on the impossible standards that women must achieve to be considered pretty; women can never be delicate enough, women can never be small enough, and women can never be "pretty" enough for society to accept them.

After this moment, Owen dives into Fantasy Owen and engages with Fantasy Rodney (dressed as a rocker) in a 1980s hair metal music video, where Fantasy Rodney repeatedly kisses Fantasy Owen while both face the audience. Fantasy Owen confesses to Fantasy Rodney that he is in love with him and wants to have his baby, then goes into labor with said baby. With the assistance of Jane Fonda as a midwife, Fantasy Owen gives birth to a baby, then places the baby on his chest and breastfeeds the baby. As this is the first moment within the play that one of the masculine characters performs as inherently feminine (performing as a love interest, becoming a mother, describing

\footnotetext{
43 "Pretty, Adj., n., and Int.," OED Online (Oxford University Press, n.d.), accessed May 1, 2019,
} http://www.oed.com.proxy.mul.missouri.edu/view/Entry/151023. 
himself as pretty), questions were raised as to the sexuality of the characters Owen and Rodney. Callaghan states:

That was a constant conversation with Kip [Fagan, the director] — how gay is the play? It's not about two guys who are in love but can't express it, but it's about two guys who will never, ever be able to feel comfortable with any kind of feminine impulses because of the way they've been conditioned by society and the way they respond to the world. ${ }^{44}$

These encounters between Rodney and Owen can only happen in Owen's fantasy because their reality's sociocultural norms could never allow any femininity they perform to be tolerated. The reason that these encounters seem disjointed or out of place is because Callaghan is allowing the audience to see what it normally is not allowed to see-men performing femininity and "girlish" romanticism. Men are the knights on the white horse, not the damsels waiting to be rescued.

After this highly feminine, “queer" performance, Reality Owen and Reality Rodney take over in the "real" world of the play, and both attempt to out-masculine each other throughout the course of the scene. This shift from the feminine performance to the masculine performance could be a response to the men "trying on" femininity; they need to reassert their masculinity in fear of losing it. As Owen attempts repeatedly to work on his screenplay, Rodney continues to interrupt and distract him, which causes the two to engage in a physical scuffle. Rodney reflects the hierarchical views that newer military members have over civilians. In "Doing Hegemony: Military, Men, and Constructing a Hegemonic Masculinity," sociologist Ramon Hinojosa studied identity construction of military men and masculinity:

One tactic for constructing an identity in-line with hegemonic masculinity is to compare the perceived qualities of service members to non-service members... The men have constructed narratives in which they possess a physically able and

${ }^{44}$ Rodgers, "Deep Conditioning: An Interview with the Playwright," 79. 
fit body inhabited by a disciplined self. These characteristics are in line with hegemonic masculinities. ${ }^{45}$

By engaging in a physical scuffle, Rodney is asserting his dominance as the "alpha" as he truly believes that his military training makes him a better man than Owen. Rodney is stronger and inherently more disciplined than Owen, so Rodney will most likely win the fight. Rodney is ultimately hurt in the fracas, however, and the second that Owen attempts to comfort and aid Rodney, Rodney calls him a "faggot." ${ }^{46}$ Owen shows a moment of femininity by attempting to comfort an injured comrade, and he is immediately punished by Rodney for it. As Kimmel claims, "Homophobic flight from intimacy with other men is the repudiation of the homosexual within—never completely successful and hence constantly reenacted in every homosocial relationship." ${ }^{47}$ The two verbally spar back and forth using the word "faggot" seven times over the course of half a page. This is the crux of the scene; neither man wants to be "gay," so they verbally spar asserting their dominance over each other. According to Kimmel, "This, then, is the great secret of American manhood: We are afraid of other men. Homophobia is a central organizing principle of our cultural definition of manhood. Homophobia is more than the irrational fear of gay men, more than the fear that we might be perceived as gay." ${ }^{\prime 4}$

Fantasy Owen appears a final time in the plot of That Pretty Pretty, with Owen playing a doctor in the war zone that is now the setting for his screenplay. Fantasy Owen first appears as a kind, sympathetic doctor who is there to take care of the bruised and battered Valerie. Agnes refers to Reality Owen while talking to Fantasy Owen: "I knew a

\footnotetext{
${ }^{45}$ Ramon Hinojosa, "Doing Hegemony: Military, Men, and Constructing a Hegemonic Masculinity," Journal of Men's Studies 18, no. 2 (2010): 183-184.

${ }^{46}$ Callaghan, "That Pretty Pretty; Or, the Rape Play," 284.

${ }^{47}$ Kimmel, The Gender of Desire: Essays on Male Sexuality, 34.

${ }^{48}$ Ibid., 35.
} 
fellow named Owen once...He was a bit of a pansy. He let me hit him. And he cried all the time. His penis was shaped like a cashew. He was in love with his best friend. He called him “The Rod.' Isn't that hilarious?"49 In response Fantasy Owen holds Valerie and Agnes hostage at gunpoint and sexually assaults Valerie in front of Agnes. This is the last time we see Fantasy Owen during the play, and during this episode his behavior codes heavily masculine. Fantasy Owen betrays the trust of Agnes and Valerie, holding them hostage to use them for his own sexual pleasure and then kills one of them in a viscerally violent and violating way, making this hypermasculine gender performance a nauseating one. Fantasy Owen justifies his actions for the sake of his country, a nationalist sentiment that echoes that of FBI Man in Roadkill Confidential. Finally, he makes the comment that he does this for "all mankind," 50 which could be the commonly accepted use of "mankind" to mean "all people," but considering the many hypermasculine performances and tropes peppered throughout the play, it may be possible that Fantasy Owen is only referring to "man"-kind.

The final scene of the play features Reality Owen onstage alone at a talkback for his film, taking questions from the audience (we do not hear the questions, they are extrapolated from Reality Owen's responses). The first question from the audience seems to be in regard to his inspiration for the film, to which he replies that he drew inspiration from two women who would go to pro-life conventions and kill men, then blog about it. ${ }^{51}$ The second question seems to query his "bleak" outlook on life, to which he replies "I do think that humans are a pretty cruel bunch...As I see it, I'm not creating reprehensible

\footnotetext{
${ }^{49}$ Callaghan, "That Pretty Pretty; Or, the Rape Play," 309.

${ }^{50}$ Ibid., 312.

51 Ibid., 313.
} 
characters, I'm merely giving voice to the unspoken." 52 Kelda Lynn Jordan interprets this "unspoken truth" as

... that he is giving voice to the fact that women are as capable of being aggressive as men. The second unspoken truth is the war between the genders. These two subjects are taboo due to the feminist fight for equality. By giving voice to these issues, he hopes to bring the subject into the open so they can be discussed and hopefully come to a resolution. Furthermore, as long as society continues to look at women on unequal levels they can not be equal. ${ }^{53}$

While Jordan's interpretation of this line of text is logical, this response could also be an attempt by Owen to absolve himself of responsibility for the characters he created in the film, what they say, and what they represent. His argument is that all humans are essentially violent, and he merely places that assertion on screen; however, very few humans are violent to the extreme levels that the characters in his screenplay are violent. Owen asserts in an answer to another question that his film is the "truth" and that people are choosing not to see the truth. Regarding his inspiration, Owen notes "Um, Jean-Luc Godard is an influence, definitely. Scorsese, uh...Mel Gibson, believe it or not...Woody Allen, David Lynch...I could go on. ${ }^{{ }^{54}}$ All the filmmakers Owen mentions are White men who have produced films that contain significant amounts of violence and center on male protagonists. The filmmakers themselves have also been associated with controversial behavior. Godard rose to fame with his gangster film Breathless, but then later was accused of anti-Semitism and was ostracized by American filmmakers for his views. ${ }^{55}$ Martin Scorsese's works are hailed by Turner Classic Movies as "meditations on

\footnotetext{
${ }_{52}^{52}$ Ibid., 314.

${ }^{53}$ Jordan, "Perspectives on Women and Aggression Illustrated Through Caryl Churchill's Top Girls, Maria Irene Fornes' Fefu and Her Friends, and Sheila Callaghan's That Pretty Pretty; or, The Rape Play," 75.

${ }^{54}$ Callaghan, "That Pretty Pretty; Or, the Rape Play," 314.

${ }^{55}$ Michael Cieply, "Godard's Hononary Oscar Raises Charges of Anti-Semitism," The New York Times, November 1, 2010, sec. Movies, accessed March 27, 2019, https://www.nytimes.com/2010/11/02/movies/02godard.html.
} 
the visceral nature of violence and male relationships that often reflected his own personal angst growing up in the violent streets of Manhattan's Lower East Side, ${ }^{, 56}$ and his breakout film, Taxi Driver, caused considerable controversy for the portrayal of Jodie Foster (aged twelve at the time of filming) as a sex worker. ${ }^{57}$ Mel Gibson, an action film star who became a director, physically embodies the hypermasculine ideal and has been widely condemned in recent years for expressing anti-Semitic views, physically abusing a former girlfriend, and making sexually violent remarks and racist slurs in a recorded phone conversation. ${ }^{58}$ Woody Allen, a filmmaker who often inserted himself into his own films continues to make headlines into 2019 for marrying Soon-Yi Previn (a daughter he adopted with Mia Farrow) and for allegedly sexually abusing another adoptive daughter Dylan Farrow. ${ }^{59}$ David Lynch, while a less controversial figure in his personal life, is noted for making films that have "some of the most memorable female characters, [but] they often become the subjects of voyeurism and also assault." ${ }^{60}$ Referencing these filmmakers invokes a tradition of gender performance that is hypermasculine (gangster films, objectifying women featured in the films and in their personal lives), the film that Owen has created fits most of the criteria of the grotesquely violent, misogynistic action film. One audience member seems to ask something about the portrayal of female characters in the film, to which Owen responds that "I don't think of them as 'female'

\footnotetext{
56 "Overview for Martin Scorsese," Turner Classic Movies, accessed March 27, 2019, http://www.tcm.com/tcmdb/person/172836|108079/Martin-Scorsese/.

${ }^{57}$ Michael Barson, "Martin Scorsese | Biography, Films, \& Facts," Encyclopedia Britannica, accessed March 27, 2019, https://www.britannica.com/biography/Martin-Scorsese.

58 “Mel Gibson," Biography, accessed March 27, 2019, https://www.biography.com/people/mel-gibson9310680 .

${ }^{59}$ Michael Barson, "Woody Allen | Biography, Movies, \& Facts," Encyclopedia Britannica, accessed March 27, 2019, https://www.britannica.com/biography/Woody-Allen.

60 “'Twin Peaks' Proves David Lynch Still Has a Woman Problem (Commentary)," TheWrap, last modified May 31, 2017, accessed April 28, 2019, https://www.thewrap.com/twin-peaks-david-lynch-womanproblem/.
} 
characters. I think of them as people. I'm an observer of the human condition, irregardless of gender. I'm 'gender-blind,' as they say." ${ }^{61}$ Jordan seems to take this statement at face value.

Owen views the women and men along equal measures. He shares the harshness of both gender realities without attempting to gain sympathy for either one. Through the play Owen illustrates the issues both genders face. Furthermore, he discusses the human qualities that are not supposed to be discussed, which are emotions for men and aggression for women. When people are thwarted from discovering themselves as individuals, and wishes [sic] to step out from under social gender constructs, they are being oppressed. ${ }^{62}$

Jordan's comments are persuasively articulated, but the fact that the entire play takes place through his gaze challenges this assertion. If all the representations of women, men, and fantasy versions of Owen and his best friend Rodney are channeled through hypermasculine tropes and overtly misogynistic in tone, it makes it difficult for Owen's argument that he is "gender-blind" to come from a sincere place. It seems rather that Callaghan is making a statement representative of what so many misogynistic filmmakers and artists make (including the ones Owen references for inspiration) that the work does not reflect their personal views, washing their hands clean of the misogyny, violence, and gender normative performances the art contains. His "gender blindness" seems similar to artists who tout that they are "color blind" when it comes to casting. August Wilson famously critiqued the color-blind casting process in his address "The Ground on Which I Stand:"

To cast us in the role of mimics is to deny us our own competence...To mount an all-black production of a Death of a Salesman or any other play conceived for white actors as an investigation of the human condition through the specifics of white culture is to deny us our own humanity, our own history, and the need to make investigations from the cultural ground on which we stand as black

${ }^{61}$ Callaghan, "That Pretty Pretty; Or, the Rape Play," 314.

${ }^{62}$ Jordan, "Perspectives on Women and Aggression Illustrated Through Caryl Churchill's Top Girls, Maria Irene Fornes' Fefu and Her Friends, and Sheila Callaghan's That Pretty Pretty; or, The Rape Play,” 76. 
Americans...The idea of colorblind casting is the same idea of assimilation that black Americans have been rejecting for the last 380 years... We want you to see us. We are black and beautiful...We do not need colorblind casting; we need some theatres to develop our playwrights. ${ }^{63}$

Callaghan's critique of "gender blindness" falls along the same lines as Wilson's critique of colorblindness. By having Owen state that he is "gender blind," he willingly erases a major aspect of the identities of Agnes and Valerie in his screenplay. When misogynistic writers reproduce these notions, they take up the space of writers who do understand the experience of women and make it more difficult for women writers to be seen or heard.

\section{Character Gender Disruption: Jane Fonda/Jane}

Jane Fonda/Jane is an outlier in terms of the characters as she evokes a real person. The real Jane Fonda is a famous Academy Award-winning American actress, human rights activist, and exercise enthusiast who faced considerable controversy in the 1970s for her outspokenness against the Vietnam War and was thus dubbed "Hanoi Jane" for her trip to the city in $1972 .{ }^{64}$ Outside of her political activism, Fonda became wellknown in the 1980s for creating several exercise videos that became enormously popular with the public. ${ }^{65}$

In the world of That Pretty Pretty, Jane Fonda is described in the dramatis personae as "female, circa '82, leg warmers et al." 66 As the real Jane Fonda's first workout video Workout premiered on April 24, 1982, it locates the character of Jane

\footnotetext{
${ }^{63}$ August Wilson, "The Ground on Which I Stand," in The American Theatre Reader: Essays and Conversations from American Theatre Magazine (New York: Theatre Communications Group, Inc., 2009), 158.

64 “Jane Fonda | Biography, Facts, Films, \& Activism,” Encyclopedia Britannica, accessed March 24, 2019, https://www.britannica.com/biography/Jane-Fonda.

${ }^{65}$ Ibid.

${ }^{66}$ Callaghan, "That Pretty Pretty; Or, the Rape Play,” 232.
} 
Fonda at a very specific point in Fonda's career_post- "Hanoi Jane," but at the fledgling beginnings of her workout empire and eventual redeemed Hollywood star. ${ }^{67}$ Her function in the play is to mainly serve as the conscience and confidant of Owen as he struggles to write drafts of his screenplay. Whenever Owen loses control over the narrative or is lost as to where to develop his screenplay next, Jane Fonda will usually appear and offer him words of caution or reassurance. Owen also states that Jane Fonda is a sort of inspiration for his screenplay as his mother idolizes her, which makes Jane Fonda's function also as a matronly figure, "pumping up" Owen to continue working his way through the screenplay with her exercise routine. As Jane Fonda says about herself:

You see how excellent I am? An inspiration. Generations of women look up to me. Do I inspire fear in you? I shouldn't. Glow glow glow, sparkle like a star. I am not someone who dominates. I am frank and dignified. I am sincere. I have loads of confidence, except when I feel abused, and then I simply raise my chin and take it. THAT'S a real woman. THAT'S heroic. And I have a kickin' bod. ${ }^{68}$

For Owen, Jane Fonda is the epitome of femininity — strong, but not too strong, inspirational, but not domineering. She asserts herself when socially acceptable to do so and leads an army of women to be just like her. Owen's version of Jane Fonda is repeated throughout the versions of the screenplay. In the British farce dinner party scene, Jane Fonda portrays a waiter. After offering black pepper to all the dinner guests, the following dialogue occurs:

JANE FONDA, frank and dignified, disappears. RODNEY She's so frank and dignified. OWEN I know. RODNEY

\footnotetext{
${ }^{67}$ History.com Editors, “Jane Fonda's First Workout Video Released," HISTORY, accessed March 27, 2019, https://www.history.com/this-day-in-history/jane-fondas-first-workout-video-released.

${ }^{68}$ Callaghan, "That Pretty Pretty; Or, the Rape Play," 251.
} 
I wish all women were like her. ${ }^{69}$

The quality that is repeated over and over again by Jane Fonda (which is then echoed in observations by the other characters) is her servitude. In each manifestation of Jane Fonda/Jane, her purpose is to serve Owen. She plays a server in the dinner party and at the hotel in which Reality Owen and Reality Rodney are staying. At other times, she serves as inspiration to the women in the play, as well as serving as a muse and inspiration for Owen as a screenwriter. It is a highly gendered dynamic that Jane Fonda and Owen perform; Jane Fonda, the woman, is in constant servitude to the man. This gendered relationship is heightened by the fact that Jane Fonda is a famous icon with a multi-media empire and that Owen is struggling to make ends meet as a screenwriter. Jane Fonda's gender overrides any power she may wield over Owen, and, as she is part of Owen's fantasy, she will never be able to overcome and take control of Owen.

Now that there is an understanding of the functions of each of the five characters, I will analyze the varying forms of violence that occur onstage within That Pretty Pretty; or, The Rape Play.

\section{Onstage Violence in That Pretty Pretty; Or, the Rape Play}

Of the four plays in this study, That Pretty Pretty features the greatest number of instances of onstage violence - nearly fifty individual acts. In addition, it has the most varied forms of violence manifested in one play. Jordan Goff references the quantity and nature of violent acts as reasons for caution when approaching this text for analysis:

That Pretty Pretty involves scenes of torture, rape, degradation, and murder, all of which [are] treated with heightened rawness that can be extremely problematic for many viewers, especially those who gloss over the comic treatment each violation

\footnotetext{
${ }^{69}$ Ibid., 265.
} 
receives. It is no wonder that the extreme violence in Callaghan's plays is sometimes misinterpreted. ${ }^{70}$

Callaghan's use of extreme violence is purposeful and methodical; if it seems excessive or gratuitous to the audience, it is intended to be so to make a point. To help make sense of these violent moments, I have broken the violence performed in That Pretty Pretty into three categories: violence with weapons, physical violence, and sexual violence. By breaking the violence up by the modality of violence, I will be able to shed light on how these acts of violence, while in seemingly different parts of the play, may speak to each other and shed light on how the characters progress through the course of the play. As Jordan's dissertation examines women and aggression in detail, I will be in conversation with her study when appropriate.

Violence with Weapons

Violence with weapons is the modality that is most commonly used by the characters within That Pretty Pretty. The most common weapon of choice is a gun. Considering that this play is set within the United States, it is not surprising that gun violence is prevalent throughout the piece. According to Everytown for Gun Safety, the average gun deaths per year in the United States with the intent to commit homicide is $12,830 .{ }^{71}$ Women are at considerable risk of being victims of gun violence as it is often used in intimate partner violence altercations; in fact, women in the United States are twenty-one times more likely to be killed with a gun than women in other high-income countries. ${ }^{72}$ According to Bureau of Justice Statisticians Alexia Cooper and Erica L.

\footnotetext{
${ }^{70}$ Goff, “'if More Women Knew More Jokes...': The Comic Dramaturgy of Sarah Ruhl And Sheila Callaghan," 76.

71 "Gun Violence in America," EverytownResearch.Org, last modified July 19, 2018, accessed March 27, 2019, https://everytownresearch.org/gun-violence-america/.

${ }^{72}$ Ibid.
} 
Smith, $88.8 \%$ of all homicides in the United States were committed by men and most were committed with handguns between $1980-2008 .{ }^{73}$ These statistics alone make the first act of violence committed within Owen's fantasy in That Pretty Pretty all the more surprising:

\section{RODNEY}

Do not leave the fucking room.

A beat. VALERIE reaches into her purse and pulls out a gun. RODNEY (cont.)

Wait. AGNES GROSS. Gross gross gross get him off me...

VALERIE helps get RODNEY off AGNES. They roll him onto the floor ${ }^{74}$

Prior to being shot, Rodney attempts to assert his dominance over Valerie and Agnes by telling Valerie not to leave the room. In a response to this masculine gesture, Valerie responds with a masculine gesture of her own by retrieving a gun and shooting Rodney in the head. As Valerie only requires one shot to kill Rodney, it is reasonable to believe that she is the one who has committed the killings in all the other states in which Valerie and Agnes have killed men. Agnes responds to Valerie's action with a more feminine gender performance by repeatedly calling Rodney's dead body "gross" and asking for assistance from Valerie to distance herself from the corpse. This is the only time in the play that women successfully use weapons to commit an act of violence. When the genders of the characters are reversed and Owen is inserted into the narrative alongside Rodney in Owen's second draft of the screenplay, however, more violence is necessary to have the same effect:

AGNES

Do not leave the fucking room.

\footnotetext{
${ }^{73}$ Alexia Cooper and Erica L Smith, "Homicide Trends in the United States, 1980-2008" (2011): 9, 27.

${ }^{74}$ Callaghan, "That Pretty Pretty; Or, the Rape Play," 239.
} 


\author{
A beat. OWEN reaches into his coat and pulls out a gun. \\ AGNES (cont.) \\ Wait. \\ OWEN shoots AGNES in the face. Them he pulls out a machete from his coat \\ and hacks her. \\ OWEN \\ Shing! Taste the blade! Skeeee-rumptious! \\ Then he pulls a sledgehammer from the closet and begins slamming it into her. \\ Blood hits the wall. \\ OWEN (cont.) \\ Rahg! World smells a whole lot better without your reeking hole... \\ He is finally done. ${ }^{75}$
}

In the second version, Agnes, Owen's former paramour, is the victim of the gun violence perpetuated by Owen. Although Rodney is present in this version and is the one who seduces Agnes, Owen is the only man who speaks in this sequence. As Jordan has argued, the inversion of gender between these two scenes transcends the polarity model of men as aggressors and women as passive: "This play exposes aggressive behaviors by both genders with deep anger driving the character's actions." ${ }^{\text {76 }}$ However, the intensity of violence is considerably heightened when the men are committing the violent acts. After Owen shoots Agnes the same way Valerie shoots Rodney, Owen mutilates Agnes' body by "hacking" her with a machete and "slamming" her with a sledgehammer. Both the machete and sledgehammer could be interpreted as phallic symbols, and his use of them reinforces the masculine nature of Owen's gender performance. Owen's lines also reinforce a masculine gender performance as he shouts things that action heroes may hurl at an opponent they have just conquered. Agnes transforms through the course of this violence from a person to an object of Owen's ire, and she loses her personhood through the violent actions of Owen, making her passive response a feminine performance.

\footnotetext{
75 Ibid., 257.

${ }^{76}$ Jordan, "Perspectives on Women and Aggression Illustrated Through Caryl Churchill's Top Girls, Maria Irene Fornes' Fefu and Her Friends, and Sheila Callaghan's That Pretty Pretty; or, The Rape Play," 61.
} 
The next time a weapon is used onstage in That Pretty Pretty is late in the play, after Owen has gone through several drafts of his screenplay. Owen is channeling Jane Fonda as inspiration to write his final draft of his screenplay. As she, Valerie, and Agnes exercise:

The women then tear their fatigues off and begin pole dancing and rubbing up against one another. OWEN stops typing a moment and watches as... RODNEY enters in army fatigues. He pulls out a rifle. He executes them, one by one. $^{77}$

The women strip their apparent masculine garb of military fatigues to engage in pole dancing and rubbing up against each other, shifting their performance from masculine to feminine. Owen stops typing to watch the women pole dance (as he has commanded them via his keyboard), and watches as his male object of desire and best friend Rodney, kills them, invoking the hypermasculine "G.I. Joe" gender performance that Owen aspires to. In addition, Rodney uses a rifle instead of a gun, which is a larger (and longer) phallic symbol used to execute the women in a hypermasculine gender performance of violence. If Owen's role as creator of the play's action has not been apparent to the audience before, this moment reveals that the entire play has been presented from his point of view and through his male gaze.

The last three moments of violence with weapons all occur within the final draft of Owen's screenplay. In the final draft of the screenplay, Valerie has been brutally gang raped by soldiers and is in the hospital recovering when Agnes, under cover in a burka, visits her in the hospital. When Agnes promises to avenge Valerie, Valerie instead encourages her to focus on spreading kindness to all the men who have lost their kindness

${ }^{77}$ Callaghan, "That Pretty Pretty; Or, the Rape Play," 304. 
through warfare. Agnes confesses to Valerie that even though they have teamed up to form a resistance to the war, Agnes' original goal was to kill Valerie for sleeping with her husband. Valerie replies:

\section{VALERIE}

Then do it, Agnes...Kill me...

AGNES pulls out a gun. She holds it up to shoot VALERIE, her arm trembling.

VALERIE (cont.) (supremely dignified)

Go on. Pull the trigger.

AGNES

I...can't...

She drops the gun and flees to VALERIE. They stare into each other's eyes for a moment. They kiss passionately. ${ }^{78}$

Rather than subvert the gender norms around women committing violence, Owen's film reinforces that women are unable to commit acts of violence. Rather than complete the act of violence and perform a masculine gesture, the two instead choose love and kindness - two qualities strongly associated with femininity. Rather than a sisterly bond, however, the women perform romantic love for each other, which queers their characters, destabilizing their gender performances. Immediately after this moment, Owen enters, dressed as a doctor with a tray of food. Owen attempts to care for Valerie in her wounded state, but is "distracted" by Agnes, who is flirting with him. Valerie attempts to leave, and vaguely familiar dialogue reoccurs:

VALERIE (wounded)

I'm going outside for a Diet Coke...

OWEN suddenly grabs the gun that AGNES dropped earlier and aims it at VALERIE.

OWEN

Do not leave the fucking room.

AGNES

Oh my God...You're one of THEM...

OWEN

That's right, American gypsy...

\footnotetext{
${ }^{78}$ Ibid., 307.
} 
He aims the gun at AGNES and grips VALERIE by her throat.

OWEN (cont.)

You two ladies thought you could defeat us with your little "resistance." Well we've had you in our sights for a long time. And payback is a total bitch. (To AGNES.) I advise you to watch carefully, Agnes. (To VALERIE.) I'm going to rape you now, Valerie.

VALERIE nods. With dignity, she leans back and spreads her legs.

AGNES

NOOO!

VALERIE

It's all right, Agnes...

OWEN prepares himself for his rape. ${ }^{79}$

Owen, in a hypermasculine move, takes advantage of the feminine performance of Agnes and Valerie by taking up the gun that Agnes put down and holding them both hostage at gunpoint. As if holding them at gunpoint was not enough, Owen then grasps Valerie by the throat, asserting his masculine dominance both with the phallic symbol of the gun and by flexing his muscles around Valerie's throat. Owen also uses a specifically gendered term to describe the two women by calling them "ladies" and associates them with a different but equally problematic gendered term by referring to the payback they are about to receive as "a total bitch." Rather than fight against her assailant, Valerie submits to Owen in a passive feminine performance. Agnes vocally protests, but also remains physically passive. Once Owen has completed the sexual assault (which will be discussed in the sexual violence section), Owen commits two more acts of weaponized violence against Agnes and Valerie.

\section{OWEN}

Now I'm going to stick a grenade in your vagina and I'm going to pull the pin. Okay?

VALERIE

Okay.

OWEN

Okay. AGNES

\footnotetext{
${ }^{79}$ Ibid., 310.
} 
You bastard!

She charges OWEN. OWEN smacks her down with the gun.

Then he removes a grenade from his pocket.

OWEN

What I do here today, I do for the good of my country, my people, and all mankind.

He sticks the grenade into VALERIE's vagina. He closes his eyes.

OWEN (quietly)

Goodnight, Maestro.

He pulls the pin. All three cringe.

Darkness. ${ }^{80}$

After Owen sexually assaults Valerie, he places a grenade, a highly masculine and phallic symbol of warfare and destruction in her vagina. When Agnes attempts to physically stop Owen from doing so, Owen strikes Agnes down by pistol whipping her. Agnes attempted to perform a daring, masculine act by attacking Owen, but is immediately punished by Owen for doing so. His masculinity out-performs hers, and he asserts this by striking her with a phallic symbol, making his masculine performance hypermasculine. The audience sees Owen pull the pin, but do not see the grenade explode inside Valerie's body. However, once a pin is pulled from a grenade, it has no other option but to detonate, making this moment a violent act already in progress.

The weapons utilized by the characters in That Pretty Pretty are frequently coded as phallic/masculine, but what happens when the characters have no weapon in hand? How do these violent behaviors get coded when the only thing at their disposal is their own body? In the next section, I will explore the manifestations of physical, nonweaponized violence performed by the characters within the play and how that impacts understanding of the characters' genders.

Physical Violence

${ }^{80}$ Ibid., 312. 
Unlike the violence with weapons, some of the physical violence that occurs between characters happens between two of the characters of the same sex. The first instance of physical violence within the play occurs during the first draft of Owen's screenplay featuring Agnes and Valerie. Owen's voice has broken through the world of the screenplay through Valerie, and when he (through Valerie) realizes he has infiltrated the world, he forces Valerie to explode with anger and bark "like a rabid dog." ${ }^{81}$ Agnes offers to help Valerie (again, really Owen):

\section{VALERIE}

Hit me in the face. Get me angry, get me all riled up.

AGNES

Fist or palm?

VALERIE

Fist. No, palm.

AGNES hits VALERIE in the face.

VALERIE (cont.)

Again.

AGNES hits VALERIE in the face.

VALERIE (cont.)

Try to get your ring into it.

AGNES turns her ring around on her finger and smacks VALERIE again. VALERIE (cont.)

Am I bleeding?

AGNES

No.

VALERIE

One more.

AGNES hits VALERIE in the face.

VALERIE

Okay.

AGNES

You mad?

VALERIE

Yeah.

AGNES

Furious?

VALERIE

Yeah, yeah. Thanks.

AGNES hits VALERIE in the face again.

${ }^{81}$ Ibid., 248. 


\section{VALERIE (cont.)}

Enough! ${ }^{82}$

At this point in the play, the audience is not aware that Agnes is hitting Valerie as a proxy for Owen; the actions, therefore, must be interpreted as if two women were involved in a physical altercation. Valerie requests that Agnes hit her with a palm instead of a fist, which increases the surface area of the strike but decreases the amount of potential damage that Agnes can inflict on Valerie. Biologists Michael H. Morgan and David R. Carrier, authors of the study "Protective buttressing of the human fist and the evolution of hominin hands," were the first to study the impact of a punch versus a slap using experienced and trained martial artists:

The striking surface area of a fist is less than one-third the area of the whole hand and $\sim 60 \%$ of the area of the palm. This means that if the total force applied in a strike is the same, then the stress in the targeted tissue will be 1.7 to 3.0 times greater in a fist strike than in a palm strike. Thus, although striking with a fist appears not to result in more forceful strikes, fists increase the peak stresses that are imposed on the target and, therefore, the potential for injury. ${ }^{83}$

Although the force used to commit a slap or a punch may be equal in effort, the punch will always be more likely to cause greater damage as the force of the punch is concentrated in a smaller surface area. Fists evolved to be used in male-male combat and to allow males to assert sexual dominance over larger groups of female mates, which also accounts for why male hands and fists are larger than female hands and fists. ${ }^{84}$ In most cultures, the formation of a fist is viewed as a masculine trait rather than a feminine trait. Valerie initially asks for Agnes to strike her with a fist, but then changes her mind to a palm, making her action shift from a masculine choice to a feminine one. The slap, being

\footnotetext{
${ }^{82}$ Ibid., 249-250.

${ }^{83}$ Michael H. Morgan and David R. Carrier, "Protective Buttressing of the Human Fist and the Evolution of Hominin Hands," The Journal of Experimental Biology 216, no. 2 (January 15, 2013): 236.

${ }^{84}$ Ibid., 242.
} 
less injurious than the potentially lethal fist, does not satisfy Valerie, so she raises the stakes; Valerie instructs Agnes to "get [her] ring into it." ${ }^{\text {" }}$ A ring would be a smaller, harder surface to make contact with Valerie's face, so the damage caused by the addition of the ring would increase. Valerie asks Agnes "Am I bleeding?" 86 in response to the slap with the ring, assuming that the addition of the ring broke the skin and caused more damage than the slap. Since the ring did not cause her to bleed, Valerie instructs Agnes to slap her one final time, but Agnes deceives her and slaps her two more times. On the surface, this seems to be a highly feminine moment in the play; two female characters are engaged in a feminine violent gesture that is repeated, but the gender performance is questioned when considering that Valerie is speaking as a proxy to Owen. Owen is the one asking Agnes to slap him, not Valerie. This challenges our ideas of gender as Owen is asking Agnes to perform on "him" a feminine violent gesture rather than Owen enacting a violent gesture on her. Owen is asking Agnes to do so to help him focus and channel his energy into the screenplay but is also reproducing the violence in Agnes and Owen's abusive relationship. The slapping, which is supposed to refuel his anger towards Agnes, instead causes him to lose steam; at that moment Jane Fonda enters and interrupts the scene with a new performance of femininity to assist Owen.

The next instance of physical violence in the play is not as high-stakes as some of the other violent moments in the play but speaks toward gender dynamics in a significant way. In the third draft of Owen's screenplay, the farcical British dinner party scene, Owen and Rodney both police the actions of Agnes and Valerie. Rodney is more effective than Owen in policing the behavior of the women; Rodney merely needs to snap

${ }^{85}$ Callaghan, "That Pretty Pretty; Or, the Rape Play,” 249.

86 Ibid. 
his fingers and the women obey his wordless requests. However, Owen must put his demands into words. When Owen tells Agnes that she drinks too much as she is raising a wine glass to her lips, the following exchange occurs:

Long silence. People eating and drinking. VALERIE reaches for the bread. RODNEY slaps her hand away. ${ }^{87}$

Although Owen polices Agnes' behavior with words, Rodney only uses action. This is a clear gendered power play by Rodney. When Valerie attempts to reach for bread, the symbol of the body of Christ as well as a traditional symbol of female fertility, ${ }^{88}$ Rodney slaps her hand away from it. Considering the fact that Jane Fonda is representative of the workout-obsessed form of femininity that is peppered throughout the play, it is also possible that Rodney is attempting to police Valerie's caloric consumption, as bread is often blamed as a source of weight gain. ${ }^{89}$ As the entire scene is taking place from Owen's point of view, the effect of the male gaze on the women and their appearances in this scene can be seen as attempts by the men to constrain women's movement and control their consumption of alcohol or food, restraining their access to anything that may "diminish" their femininity or beauty. The male gaze in this scene becomes more prominent with the second instance of physical violence within this scene. Rodney tells a story about his time in the war, and Jane Fonda enters, bringing a tray of Jell-O for dessert:

JANE FONDA dumps the Jell-O into the table. AGNES and VALERIE climb into the Jell-O table. JANE FONDA retrieves a whistle.

\footnotetext{
${ }^{87}$ Ibid., 265-266.

88 "Bread, Symbolism of | Encyclopedia.Com," accessed March 28, 2019, https://www.encyclopedia.com/food/encyclopedias-almanacs-transcripts-and-maps/bread-symbolism. ${ }^{89}$ Elizabeth M. Ward, MS, and RD, "The Truth About Bread and Your Diet," WebMD, accessed March 28, 2019, https://www.webmd.com/diet/features/truth-about-bread-and-diet.
} 
AGNES and VALERIE face off. JANE FONDA blows the whistle. AGNES and VALERIE begin to wrestle in the Jell-O, as RODNEY and OWEN scream from the sidelines and chomp on their cigars, throwing down more money.

This goes on for quite a while; a full match. Someone wins. The winner of the betting collects his money.

Then JANE FONDA retrieves two feather pillows. She hands one to AGNES and one to VALERIE. She blows her whistle.

AGNES and VALERIE begin to hit each other with the pillows, giggling like little girls. RODNEY and OWEN watch, eating popcorn.

The pillows eventually explode into feathers and cover the girls. They giggle like crazy.

RODNEY and OWEN cheer.

After a moment, VALERIE becomes aggressive. She beats AGNES down with her pillow until AGNES is screaming in fear.

VALERIE exits. OWEN regards AGNES in a puddle on the floor, Jell-O-ed and covered in feathers.

RODNEY pours his remaining popcorn onto AGNES and the floor. OWEN and RODNEY laugh and slap hands. RODNEY exits.

JANE FONDA begins to clean up the mess. OWEN looks sheepish. ${ }^{90}$

Jell-O wrestling, often a form of wrestling seen at parties in the United States, usually

features two women in bathing suits attempting to dominate each other while the slimy

substance makes it difficult for them to grab hold of one another. 91 "Someone" wins the

match - it does not matter whether it is Agnes or Valerie as both of the characters' bodies

are being used and exploited for the gratification of Rodney and Owen. Agnes and

Valerie then turn the Jell-O wrestling, already a highly sexualized feminine performance,

into a pillow fight, which invokes the male fantasy element of this feminine gender

performance. The "fun" the characters are having in this moment quickly turns dark as

Valerie shifts and becomes more aggressive, violently beating Agnes with a pillow.

When this shift occurs, Valerie's performance shifts from a highly feminine performance to a more masculine performance, whereas Agnes' performance becomes more feminine

\footnotetext{
${ }^{90}$ Callaghan, "That Pretty Pretty; Or, the Rape Play," 270.

${ }^{91}$ Sandy Kaye, "JelloWrestling.Com,” accessed March 28, 2019, https://fun.jellowrestling.com/jellowrestling-homepage.
} 
as a damsel in distress. When Valerie's violent act is completed, she exits, leaving the audience with the image of Agnes crumpled on the floor covered in Jell-O and feathers. Instead of offering to assist her, Rodney approaches Agnes and pours the popcorn he has been eating during the fight on top of her, degrading her and symbolically implying that Agnes' only value to him is as his entertainment. Rodney and Owen "slap hands," indicating that Owen is complicit and in agreement with Rodney for performing this masculine gesture. Jordan aptly describes this moment as a clear illustration of the "male gaze":

The women are performing for the men according to their desires, and since men view women as objects with less power, Owen and Rodney do not understand why they want to view the women fighting. The scene alludes to voyeurism towards women as being normal, adhering to the definition of the 'male gaze.' 92 But Callaghan goes beyond depicting the "male gaze" to an attempt at deconstructing it. This highly sexual and exploitative moment in the play is a manifestation of Owen's fantasy. He longs to watch women (especially Agnes) perform in accordance to his desires, but cannot put his finger on why he longs to do so. This is why at the end of this set of stage directions he appears "sheepish." Now in the absence of the man he has been trying to impress, Rodney, Owen has an opportunity to reflect on his actions when confronted by Jane Fonda. He knows he has been perpetuating masculine fantasy and that what he has created is problematic, but he provides no answers for his fantasy. Internally, he knows it is wrong, but acts as though he cannot help his male gaze and male fantasy as they are a part of him. Jane Fonda offers herself as a source of catharsis for Owen so he

\footnotetext{
${ }^{92}$ Jordan, "Perspectives on Women and Aggression Illustrated Through Caryl Churchill's Top Girls, Maria Irene Fornes' Fefu and Her Friends, and Sheila Callaghan's That Pretty Pretty; or, The Rape Play," 67.
} 
can channel his creative energy more clearly by making herself a punching bag for his rage towards Agnes:

JANE FONDA braces herself.

JANE FONDA (cont.)

I am she, now. The demon.

OWEN punches his hand, hard. JANE FONDA reacts as though she is being beaten.

JANE FONDA (cont.)

The liar.

OWEN punches his hand. JANE FONDA reacts.

JANE FONDA (cont.)

The bottomless eater.

OWEN punches his hand. JANE FONDA reacts.

JANE FONDA (cont.)

The child.

OWEN punches his hand. JANE FONDA reacts.

JANE FONDA (cont.)

The slut.

OWEN punches his hand. JANE FONDA reacts.

JANE FONDA (cont.)

The cock-tease.

OWEN punches his hand. JANE FONDA reacts.

JANE FONDA (cont.)

The vomiter.

OWEN punches his hand. JANE FONDA reacts.

JANE FONDA (cont.)

The come-hitherer.

OWEN punches his hand. JANE FONDA reacts.

JANE FONDA (cont.)

The make-you-cry-er.

OWEN punches his hand. JANE FONDA reacts.

JANE FONDA (cont.)

The hair-sprayer.

OWEN punches his hand. JANE FONDA reacts.

JANE FONDA (cont.)

The gown-wanter.

OWEN punches his hand. JANE FONDA reacts.

JANE FONDA (cont.)

The makeup-wearer.

OWEN punches his hand. JANE FONDA reacts.

JANE FONDA (cont.)

The use-all-the-hot-waterer.

OWEN punches his hand. JANE FONDA reacts.

JANE FONDA (cont.) 
The won't-shut-upper.

OWEN punches his hand. JANE FONDA reacts.

JANE FONDA (cont.)

The cheater.

OWEN punches his hand. JANE FONDA finally falls.

OWEN

Are you okay?

JANE FONDA (with dignity and grace)

Of course. It's my job. ${ }^{93}$

What is an interesting choice with this moment in the play is that Callaghan has created Brechtian spectatorial distance for the audience; they are seeing the action unfold by Owen punching his own hand, but can deduce that each blow is supposed to land on Jane Fonda. What creating this distance does is help the audience focus on the words that Jane Fonda is saying rather than the violent actions. Jane Fonda, by standing in for "the demon" Agnes, recites several gendered stereotypes generally coded feminine. Owen's violence is masculine, but is being inflicted on the self (his other hand) rather than on Jane Fonda, but Jane Fonda still feels the consequences of Owen's violence. This could also be interpreted as a feminine performance on Jane Fonda's part as she is taking on the burden of Owen's pain as a caretaker and receiving the brunt of the burden on his conscience. This is a blatant illustration of misogyny (one of many) within That Pretty Pretty.

The last instance of physical violence in the play is a test of masculinity between Reality Owen and Reality Rodney. Rodney has repeatedly attempted to distract Owen from completing his screenplay, which causes Owen to explode with anger:

OWEN

SHUT THE FUCK UP? PLEASE? a) You see me working here, b) this room is going to smell like piss all night, c) you promised you would let me fucking work if I brought you here, and d) you sound retarded.

${ }^{93}$ Callaghan, "That Pretty Pretty; Or, the Rape Play," 271-273. 
A beat. RODNEY smacks the back of OWEN's head.

OWEN (cont.)

Don't hit me, man.

RODNEY smacks the back of OWEN's head again.

OWEN (cont.)

Don't do it again.

He does it again.

They scuffle, wrestle, etc [sic], hurling each other playfully around the

room.

OWEN (cont.)

Fucker...

RODNEY

Pussy...

RODNEY accidentally slips off the bed and slams his face against

OWEN something hard.

Whoa. You okay man?

RODNEY

Think so. ${ }^{94}$

This series of violent acts sounds like two siblings fighting over a toy. Rodney chooses to smack Owen in the back of the head repeatedly, which is a violent gesture more playful than lethal. The two then engage in a schoolyard-style wrestling match, which is much more masculine in tone than the Jell-O wrestling match seen earlier in That Pretty Pretty. This wrestling sequence is not observed by any other characters, which sharply contrasts the voyeurism and male gaze that Agnes and Valerie experience while Jell-O wrestling. In addition, Rodney calls Owen a "pussy," which pushes Rodney's gender performance to a heightened masculine state that comes crashing down once he slips off the bed. The instant Rodney is potentially injured, the play-fighting stops, and Owen checks on Rodney to see if he is hurt. This shifts Owen's gender performance from masculine to feminine, as he transforms from combatant to caretaker.

${ }^{94}$ Ibid., 282-283. 
While some of the most benign acts of violence occur within the physical

violence section, the sexual violence committed in That Pretty Pretty is highly triggering and potentially troubling to readers and audiences alike, no matter who is committing the acts of sexual violence.

Sexual Violence

Some of the most reprehensible acts of violence that occur within That Pretty Pretty are forms of sexual violence. Many of the acts of sexual violence within the play share similar elements (whether it be lines, characters, or form). The first act of sexual violence that occurs within That Pretty Pretty is an act of necrophilia in Owen's first draft of the screenplay; Agnes uses Rodney's corpse as a source for her sexual release:

AGNES straddles RODNEY's leg and begins humping it.

VALERIE returns with two Diet Cokes.

AGNES (cont.)

Val...do the other leg...

VALERIE

Uh-huh.

AGNES

Come on...

VALERIE

I'm drinking my Diet Coke.

VALERIE connects her camera to the computer. AGNES grabs RODNEY's bottom lip again as she humps.

AGNES

'I really like skinny girls. How did you get so fucking skinny...' Starving myself and drinking water and longboarding my face off...I can't wait 'til summer...my metabolism speeds up in the summer...I'd burn more calories during sex if it took me longer to get off...

VALERIE

Then take longer...

AGNES

I...can't...

AGNES climaxes. VALERIE hands AGNES a Diet Coke. ${ }^{95}$

${ }^{95}$ Ibid., 243-244. 
There is no question that this section, seen in Owen's first draft of his screenplay, is highly grotesque. What it does present is a power shift in gender performance of sexuality. Rodney, or, rather, Rodney's corpse, is passive in this sexual act, making his gender performance feminine. Agnes, the active party, is performing masculinity in this moment as she is on top of Rodney in the sexual act and humping his leg as dogs do. She is in control of her sexual satisfaction rather than Rodney, and she climaxes quickly, which is a stereotype commonly associated with masculine sexuality. This continues to destabilize Agnes' gender performance as her behaviors are masculine, but the goal is feminine pleasure and satisfaction.

The second version of Owen's screenplay shows both consensual and nonconsensual sexual violence. A dominant feature in the second version is sadomasochist play between Rodney and Agnes. After Rodney performs a "complicated hip-hop move" and is teased about it by Owen, Rodney reacts with violence towards Agnes:

\section{RODNEY}

Shut UP, dude.

\section{OWEN}

RODNEY grabs AGNES by the hair. She does not react.

He thinks if he can get on the air, he'll ask him to dance.

RODNEY

Most people think he's gross but he's got these ice-blue eyes, that's why he wears sunglasses all the time.

RODNEY shoves AGNES onto the bed and presses his knee into her back., still holding her hair, and begins to tear off her clothes.

Again, she does not react. As a matter of fact, it seems to have a calming, pleasant effect on her.

OWEN pulls out a pack of cigarettes He begins by lighting them one by one and putting them out on AGNES's body. ${ }^{96}$

While in most cases the masculine gestures of pulling Agnes by the hair, holding her down, ripping clothes off, and extinguishing cigarettes on her would be considered

\footnotetext{
${ }^{96}$ Ibid., 254-255.
} 
abusive, Callaghan notes that these events "have a calming, pleasant effect on her," which could imply that Callaghan wants the audience to believe that Agnes is consenting to all of these actions, even if she doesn't give verbal consent. In a sadomasochist dynamic, Agnes is performing as the submissive, which codes her gender performance as feminine, whereas Rodney is performing as the dominant (or dom), which codes his gender performance as masculine. This sexual sadomasochist play continues between them:

RODNEY begins to tie AGNES up in the style of Abu Ghraib. He places a pillowcase over her head and attaches electric wires to her hands. RODNEY He's letting me have you first, he NEVER does that. He shocks her five times, and each time she lets out a shout of delight. OWEN Sweet. That's some subversive shit right there. That is CONTROVERSIAL. But that's the point, right? When you hit a nerve? POLARIZING. Some people just don't have the stomach for social commentary. They want butterflies and Bambi. Well fuck 'em. Right? Not my audience. I'm not the man with the lullaby, I'm the man with the MACHETE. A fugitive. Slicing down your tidy little forests. Everything that makes you feel safe? Shing. The lies you tell yourself? Shing. Truth to power. Burn it down, bitches. ${ }^{97}$

Callaghan's voice as playwright trickles through this monologue from Owen.

Commenting on the "subversive shit" that may be "polarizing," Callaghan directly calls attention to the subversion within the play. At this moment, Callaghan is simultaneously poking fun at artists who use sadomasochist play as a subversive, sexy edge to their works without adding substance; at the same time, she inserts it into her own work as a nod to the other subversions (with gender, violence, and gender roles) within it. At each turn, the stakes of the sadomasochistic play increase, which heightens the submissive feminine performance of Agnes and the dominant masculine performance of Rodney.

${ }^{97}$ Ibid., 255-256. 
This sexual play is complicated by the fact that images of Abu Ghraib are invoked through their sexual play. Goff discusses the problematic nature of invoking this imagery:

The all-too-familiar images of US soldiers torturing prisoners at Abu Ghraib prison flooded the media and inspired necessary, and often horrifying, discussions about where the line of human decency is drawn in regards to prisoners of war. Callaghan's explicit stage directions revive that discussion on stage in front of us, placing this featured historical moment of dehumanization in the context of systematic dehumanization of women. ${ }^{98}$

This image of a woman tied up in the style of Abu Ghraib for sexual satisfaction is a complicated one as it seems dehumanizing on the surface, but Agnes is consenting to it as a part of her submissive sexual play. It is also dehumanizing in the fact that the audience can no longer see her face by having her head covered with a pillowcase. When Agnes receives electric shocks, the audience would assume she would cry out in pain, but instead, she "lets out a shout of delight," continuing her submissive feminine performance. Immediately after this moment, Owen comments on how "subversive" and "CONTROVERSIAL" his screenplay is, but this time is playing himself in the screenplay instead of playing Valerie. He refers to himself as "the man" twice and makes reference to his "MACHETE" (another phallic symbol reference). Because he is not the one dominating in the sadomasochist play with Agnes, the only way he can assert his masculine performance is by commenting on how hypermasculine he and his screenplay are. After Owen shoots Agnes in the head and kills her, he instructs Rodney to pose with Agnes' corpse:

OWEN (cont.)

Keep the fucking bonnet on.

RODNEY pretends to be raping AGNES's body. OWEN (cont.)

\footnotetext{
${ }^{98}$ Goff, “'if More Women Knew More Jokes...': The Comic Dramaturgy of Sarah Ruhl And Sheila Callaghan," 86.
} 
Hoo-hoo! Beauteous. ${ }^{99}$

Rodney continues to assert his masculine dominance over Agnes' passive, lifeless, feminine body, and Owen, who is unable to perform the act himself, comments on how "Beauteous" this hypermasculine gender performance is that he has created.

The final instance of sexual violence in That Pretty Pretty occurs in Owen's final draft of his screenplay. Owen's disguise as the helpful doctor has been shed to hold Agnes and Valerie at gunpoint. Agnes has attempted to plead with Owen to stop him from sexually assaulting Valerie, but Owen rejects her pleas.

OWEN (cont.)

Keep the fucking burka on.

OWEN begins to rape VALERIE as AGNES watches in horrified silence. AGNES begins to cry.

OWEN (cont.)

Look, your sister is crying! But you haven't cried once, Valerie. You are so dignified. You won't cry, will you?

VALERIE

No.

OWEN

I know you won't. You have too much class for that. You are dignified and heroic.

VALERIE

Thank you.

OWEN

You're welcome.

OWEN continues his rape. He climaxes.

OWEN (cont.)

I'm done raping you now, Valerie. You did very well. ${ }^{100}$

All the performances within this violent moment fall in line with gender expectations. Agnes is horrified by what she sees and cries because of it, yielding a feminine gender performance. Owen sexually assaults Valerie, using her for his own sexual gratification to the point of climax, making his performance highly masculine. Valerie submits to her

\footnotetext{
${ }^{99}$ Callaghan, "That Pretty Pretty; Or, the Rape Play," 258.
}

${ }^{100}$ Ibid., 310-311. 
sexual assault as her only other option is death, making her an object for Owen to use, making her performance feminine. As subversive as Reality Owen thinks his screenplay may be, it plays directly into hypermasculine fantasy by objectifying, exploiting, and terrorizing women in the process.

\section{Conclusion}

In That Pretty Pretty, Callaghan hoped to expose and critique the misogyny and sexism that populated not only plays, but American society in the 2000s. ${ }^{101}$ To do so, she employs excessive amounts of violence and hypergendered performances; she makes no effort to hide, disguise, or diffuse the misogyny and brutality within the play. After pummeling the audience with violence, brutality, sexual violence, and overt sexuality, Callaghan shifts the tone of the piece entirely with the final scene of the play. Owen, taking questions from an audience during a talkback, acts as though his work is wellreceived, joking with the audience and speaking with distinction as though the work he has produced has significant cultural meaning. Then, the play ends in an absurd silence:

\section{OWEN (cont.)}

One last question, yes.

He sips his water and listens.

This question has clearly blown his mind. He's at a loss. He leans into the mike. He opens his mouth to speak. He closes it. He opens it again. He closes it. He opens it again.

This goes on for a bit.

Black out.

End of play. ${ }^{102}$

${ }^{101}$ Callaghan, "Preface," xv.

${ }^{102}$ Callaghan, "That Pretty Pretty; Or, the Rape Play," 315. 
What Callaghan has presented at the end of That Pretty Pretty is a classic Theatre of the Absurd technique. According to theatre critic Martin Esslin, who coined the term, "In the Theatre of the Absurd...the real content of the play lies in the action. Language may be discarded altogether." ${ }^{\prime 103}$ For the entirety of the play, the audience has been immersed in Owen's thoughts and point of view on women, men, gender, violence, and what makes a "good" screenplay. In his "moment of glory" at the end of the play, he answers questions from the same audience he has just barraged with misogyny and sexism only to be confronted with a question so surprising, so astounding that he is finally at a loss for words. Considering Callaghan's desire to interrogate why these images are so compelling and yet so problematic, my interpretation of this moment is that Owen is questioned about the problematic nature of his screenplay and how he could possibly view what he has presented as acceptable or progressive. Stunned that anyone could ever question his artistic integrity and the quality of his work, Owen is unable to speak, knowing any answer he may provide will ultimately turn into an excuse or an apology for his work, which he is too prideful to give. From this, I suggest that Callaghan's silencing of Owen is a pointed message about gender - the men need to be silenced; women should tell their own stories and can only do that when men clear the stage.

A majority of the moments of violence within That Pretty Pretty are happening within Owen's screenplay, and there is something that is "off” about them. They are too intense for an audience to believe realistically. Because there is dissonance between the gender performances and the violence the characters enact in the play, the gender performance and violence read as absurd. This absurdity makes many of these violent

\footnotetext{
${ }^{103}$ Martin Esslin, "The Theatre of the Absurd," The Tulane Drama Review 4, no. 4 (May 1960): 12.
} 
moments, which often veer into the grotesque, as comedic. The only way that Callaghan can demonstrate the absurdity of gendered expectations of both men and women, as well as point to the complicity of the connection between toxic masculinity and militarism to violence and misogyny, is to present them in a form that is so outlandish that it would be impossible for an audience or a reader to miss. This absurdity is at its best when the same violent hotel scene is presented twice with the genders of the characters swapped. This sequence in That Pretty Pretty seems to be a direct embodiment of Judith Butler's ideas of gender performance as parody:

Practices of parody can serve to reengage and reconsolidate the very distinction between a privileged and naturalized gender configuration and one that appears as derived, phantasmatic, and mimetic - a failed copy, as it were. And surely parody has been used to further a politics of despair, one which affirms a seemingly inevitable exclusion of marginal gender from the territory of the natural and the real...As the effects of a subtle and politically enforced performativity, gender is an 'act,' as it were, that is open to splittings, self-parody, self-criticism, and those hyperbolic exhibitions of 'the natural' that, in their very exaggeration, reveal its fundamentally phantasmatic status. ${ }^{104}$

By demonstrating the absurdity of these gender performances, Callaghan is critiquing the absurdity of all gender roles, norms, and expectations. Again, her use of Camp humor heightens the artifice of these absurd gender performances. To the extent that Callaghan parodies feminine gender performance, she equally parodies and questions masculine gender performance. While Callaghan is complicit in trafficking these tropes, she is equally exploding them and invalidating them through parody and camp.

${ }^{104}$ Butler, Gender Trouble: Feminism and the Subversion of Identity, 200. 


\section{CHAPTER FOUR}

\section{Killing Women: "What is execution but, literally, the opposite of who we are?"}

\section{Introduction}

When searching for plays in which women commit acts of violence, I was struck by the title of this play. Killing Women? I snatched it off the shelf and looked at the back cover. I was delighted when I discovered that this play not only centered women, but centered hitwomen. While this type of woman is popular in film and television (Kill Bill, Red Sparrow, Atomic Blonde, and Killing Eve to name a few), it is rare to find a play that portrays the psycho-social implications of these characters. With its razor-sharp wit and social commentary, I quickly fell in love with this script and wanted to bring attention to Marisa Wegrzyn's work.

Killing Women by Marisa Wegrzyn was originally developed in 2002 as a part of the WordBRIDGE Playwrights Lab at Eckerd College and the Performing Arts Department at Washington University in Saint Louis when she was a student there. ${ }^{1}$ Wegrzyn has been elusive when it comes to speaking about her own work, often providing short answers to deep questions from interviewers. Her blog, Chainsaw Calligraphy, is equally sparse when it comes to discussing the meaning of her own work, although the violent implications of its title are intriguing, and it has not been updated since February 2011. ${ }^{2}$ Her Twitter page, @ howdymarisa, is updated with some

\footnotetext{
${ }^{1}$ Marisa Wegrzyn, Killing Women (New York: Broadway Play Publishing Inc., 2014), n.p.

2 Marisa Wegrzyn, "Marisa Wegrzyn's CHAINSAW CALLIGRAPHY," Chainsaw Calligraphy, n.d., accessed April 6, 2019, http://chainsawcalligraphy.blogspot.com/.
} 
frequency, but contains mostly comedic punchlines about current events. ${ }^{3}$ Because of this, it is hard to tell what may have inspired Wegrzyn to write Killing Women, but the message of the play seems profoundly feminist in its representation of gender roles. The play, set in the present and "various places," serves as satirical commentary on the challenges of motherhood and working women encountering the glass ceiling in maledominated workforces. In this chapter, I will investigate how the gender performance of the characters and acts of violence in this play disrupt gender assumptions with particular attention to the gendered organizational structures of criminal organizations.

\section{Summary of Killing Women}

Wegrzyn uses organized crime (a highly gendered, hierarchical structure) as the workforce the women in the play attempt to break into. As the play opens, Gwen, a housewife, waits for her husband Baxter to return home. A member of an unnamed crime organization, he returns with Abby (his co-worker and lover) in tow, and there is awkward tension between the three. Abby tries to tell a joke in poor taste, which makes Baxter laugh, and Gwen pulls a gun out of her bathrobe and shoots him dead. The scene transitions to Lucy, another member of the organization, who is preparing for a date with a hit named Joe Lunchbox. Abby reveals to Lucy that Gwen killed Baxter, and that Abby's new job is to kill Gwen. Instead, Lucy suggests recruiting Gwen to work for the crime organization. Crime-boss Ramone is at first highly resistant to the idea of recruiting Gwen. After deliberation, Ramone agrees to allow Abby to train Gwen for a week-if she does not take to working for the organization, Abby will have to kill Gwen and

\footnotetext{
${ }^{3}$ Marisa Wegrzyn, “@howdymarisa,” Social Media, n.d., accessed April 6, 2019, https://twitter.com/howdymarisa.

${ }^{4}$ Wegrzyn, Killing Women, n.p.
} 
Gwen's daughter, Tess. Abby then goes to Gwen's apartment and gives Gwen her first assignment — to kill Johnny Duke, another hit. Gwen protests, arguing that she needs to take Tess to school the next day, she's not a trained killer, and she does not want to learn how to be one. Abby calls both Mike and Lucy to see if either of them would be willing to babysit while Abby teaches Gwen how to kill. During her phone call with Lucy, Gwen grabs a gun and holds it to Abby's head. Lucy reveals to Gwen that since she lives in the apartment across the street she will watch Tess during the hit. As Gwen and Abby stake out the hit at a coffee shop, Gwen almost blows their cover, much to Abby's chagrin. Lucy joins them at the coffee shop after dropping Tess off at school, and Gwen successfully executes the hit in the alley behind the coffee shop. Gwen leaves to go pick up Tess, leaving Abby to dispose of the body. Abby visits Gwen on another day to check her progress and discovers her cleaning up a game of Monopoly she has been playing with Wyatt, the man within the crime organization who is next in line to take over (despite Abby's greater experience). Lucy comes over to teach Gwen how to use drugs to poison hits instead of using a gun, and Abby is the test subject. As Gwen practices by injecting Abby, Gwen reveals that she has killed Wyatt, another hitman in the crime organization sent by Ramone to kill her. When Abby regains consciousness, Gwen states that she was able to get Wyatt's body to her car. Gwen's neighbor, Cooper, appears out of the bathroom, and the women tie and bind him. Abby instructs Gwen to kill Cooper as he knows too much, but Lucy intervenes, revealing that she and Cooper are in love. While Abby is confronting Lucy about the problem with falling in love with people who are destined to die, Mike Sanders, another member of the crime organization, appears at the window and tells Abby that he is in love with her and wants to go on a date with her. 
Cornered, she agrees. Abby calls Ramone asking to meet him, then warning Gwen to take her daughter and hide somewhere as the likely next step is that Abby will have to kill them both. When Abby meets up with Ramone, it is revealed that Ramone hired Wyatt to kill Gwen during the Monopoly game. Abby does not tell Ramone that Gwen killed Wyatt, but Ramone is suspicious of Abby. Abby goes to Lucy's apartment and finds that Gwen is still there. Ramone shows up with Mike Sanders and standoff occurs. After much back and forth arguing, Abby is fired, Gwen is promoted, and Ramone and Mike leave. Despondent, Abby is at a loss of what to do. Gwen asks Abby to take Tess to career day the next day, which Abby agrees to do. The final scene portrays Abby asking Tess's class for help in finding some guidance and direction in her life. She reads the class Tess's story, Princess Tess and the Moon Monsters, which is a story about female empowerment where the princess "could do anything. Anything at all. She could even fix the moon."

\section{Character Gender Disruption: Abby}

Like those of Callaghan, Wegrzyn's character descriptions are minimal and open to interpretation. Abby, one of the main assassins in the play, is described as "female, 30s-wears black well." ${ }^{\prime 6}$ Character name origins seem to have importance for Wegrzyn, as she has mentioned "Search[ing] the Social Security online baby name database for the right character names."7 The name Abby is a diminutive of Abigail, which is Hebrew in

\footnotetext{
${ }^{5}$ Ibid., $79-80$.

${ }^{6}$ Ibid., n.p.

7 "Interview with Marisa Wegrzyn | Steppenwolf Theatre," accessed September 5, 2018, https://www.steppenwolf.org/articles/interview-with-marisa-wegrzyn/.
} 
origin meaning "my father is joyful."» Within the context of the play, Abby's actual father is not a character nor discussed at length, but her crime boss Ramone may be viewed as a father figure by Abby. She does want to please him and to make him happy, but these desires may be more motivated by self-preservation than by familial love and connection.

Two of the main gender issues that Abby encounters in the play are sexist double standards and hitting a glass ceiling within the crime organization. In Scene Two, Abby asks Ramone to hire Gwen as Abby thinks she will be a great asset to the team. Ramone is resistant to this for a variety of reasons. First, he states that because Gwen has a daughter, she should not join the crime organization. Abby's argument highlights gender discrimination in this attitude:

ABBY: You hired Baxter when you knew he had a daughter. RAMONE: That's different.

ABBY: How is that different?

RAMONE: It's different 'cause it's different. ${ }^{9}$

What Ramone is not willing to admit is that hiring Gwen would be different from hiring Baxter because Baxter as a man is not expected to have the same duties of raising a daughter as Gwen would. Feminist scholar Joan Acker comments on the gendered and hierarchal nature of workplaces in her famous essay "Hierarchies, Jobs, Bodies: A Theory of Gendered Organizations:"

The abstract, bodiless worker, who occupies the abstract, gender-neutral job has no sexuality, no emotions, and does not procreate... Sexuality, procreation, and emotions all intrude upon and disrupt the ideal functioning of the organization, which tries to control such interferences. However...the [allegedly genderneutral] worker is actually a man, and it is the man's body, its sexuality, minimal

\footnotetext{
8 “Abby: Name Meaning, Popularity, and Similar Names," accessed April 5, 2019, https://nameberry.com/babyname/Abby.

${ }^{9}$ Wegrzyn, Killing Women, 9.
} 
responsibility in procreation, and conventional control of emotions that pervades work and organizational processes. ${ }^{10}$

Because Acker argues that there is no gender-neutral workplace, Wegrzyn's choice of using a crime organization to dramatize gender bias in the workplace minimizes the chance of the audience missing the central message of the play. Law professor Margaret Beare has revealed how double standards and essentialist gender notions are specifically perpetuated in criminal organizations:

Based on the largest amount of literature, women typically have supportive family-oriented roles in the mafia but may take over managerial and leadership functions if something happens to the males-leading one to assume that there are gendered roles in the mafia that women assume only in a situation of crises [sic]. Furthermore, the literature indicates that females internationally commit far fewer crimes than males and that their participation in crimes decreases as the level of violence required to carry out the criminal activity increases (Savona 2003, 104). ${ }^{11}$

Even though Baxter was a parent, Ramone is reluctant to hire a woman with a child for the crime organization even though she is a better shot than Baxter (as evident by her ability to kill him). Even though Ramone did hire the childless Abby as a hit woman, she is also subject to his gender biases. She complains that Ramone is assigning Baxter better "jobs" than he assigns to Abby, even though she has been there longer. Wyatt, a lessexperienced hitman, is also ahead of Abby in promotion despite her greater experience. Historically, organized crime (like many corporate structures in America) has been predominantly or exclusively male, and only in the last twenty years or so have women become more involved in its operations. In fact, the name "mafia" often translates to

\footnotetext{
${ }^{10}$ Acker, "Hierarchies, Jobs, Bodies: A Theory of Gendered Organizations," 151-152.

${ }^{11}$ Margaret Beare, Women and Organized Crime (Canada: Research and National Coordination Organized Crime Division, Law Enforcement and Policy Branch, Public Safety Canada, 2010), 43-44.
} 
"manly," and members of these male-only organizations were known as "Men of Honor." ${ }^{12}$ Beare explains:

In many cases, mafia based groups may be less open to women in dominant roles because in order to monopolize across various illegal markets, the ability to intimidate is a key determinant of one's standing, however, some research has indicated that women employ behind the scene roles in this area. Other organized crime operations that are more 'entrepreneurial' and are open to those who have access to a supply of illicit goods, transport, and/or distribution, may be more gender blind and open to the emancipation of women. ${ }^{13}$

The ability to intimidate, a decisive factor in ranking within organized crime, is considered a masculine attribute. Ramone confirms this belief within the scene with his explanation that he "was giving [Abby] the jobs that were least likely to give [her] a hard time." ${ }^{\prime 4}$ Abby begins to point out the flaws in her other male co-workers Miles (not seen in the play) and Mike Sanders, and Ramone asks Abby about his other top hitman Wyatt. Abby does not respond, and Ramone reveals to Abby that he will be stepping down from running the crime organization and placing Wyatt in charge. Abby protests this decision on the same grounds that she protested unfair job assignments. She has been with the crime organization longer than Wyatt has and is more experienced and deserving of the promotion than he is. Her protest, however, is futile. Sociologist Valeria PizziniGambetta has also explored gender inequity in organized crime, particularly in mixedgender organizations:

Organizational structures clearly shape the roles women play in organized crime. In mixed-gender operations, women largely are subordinate and peripheral. In small to medium-sized groups that are exclusively female and where illegal trades are open to competition, women are able to reach leadership roles. Monopolistic

\footnotetext{
${ }^{12}$ Wesley B. Knowles, Organized Crime in the U.S, Criminal Justice, Law Enforcement and Corrections Series (New York: Nova Science Publishers, Inc, 2010), http://proxy.mul.missouri.edu/login?url=http://search.ebscohost.com/login.aspx?direct=true\&db=nlebk\&A $\mathrm{N}=387208 \&$ site $=$ eds-live \&scope $=$ site.

${ }^{13}$ Beare, Women and Organized Crime, 44.

${ }^{14}$ Wegrzyn, Killing Women, 10.
} 
illegal markets remain resilient to removing gender barriers, let alone to accepting female leadership. ${ }^{15}$

As this is a mixed-gender, monopolistic illegal crime organization, Ramone reflects precisely the resistance to female leadership that Pizzini-Gambetta points out, and he even voices displeasure that more than one woman is a part of it.

Throughout the play, Abby repeatedly performs acts that are coded masculine. She resists going on a date with Mike Sanders, attempts to take on leadership roles within the crime organization, including mentoring Gwen through the process of becoming a hitwoman, and she challenges anyone who opposes her. She seems aware that she is being discriminated against because of her gender, and she speaks up about it (albeit unsuccessfully). She is a poster child for workplace gender discrimination.

\section{Character Gender Disruption: Lucy}

Lucy, another subversive and disruptive character in Killing Women, is described as "female, 30s—-sophisticated elegance." "16 Her name is a derivative of Lucius and Lux from Latin, meaning "light." ${ }^{\prime 17}$ Like Abby, Lucy is a hitwoman, a member of a criminal organization. Lucy, however, serves up her murders with interesting twists, exhibiting contradictory behaviors in her gender performance. She embodies some of the qualities of the "black widow" murderer, a misogynistic female archetype who romances her male hits before she kills them. ${ }^{18}$ Lucy also exhibits the stereotypical feminine behavior of having undue concern with physical appearance. She tries to avoid stress because

\footnotetext{
15 Pizzini-Gambetta, “Organized Crime: The Gender Constraints of Illegal Markets,” 460.

${ }^{16}$ Wegrzyn, Killing Women, n.p.

17 "Lucy: Name Meaning, Popularity, and Similar Names," accessed April 5, 2019, https://nameberry.com/babyname/Lucy.

18 "Black Widows on the Web," Psychology Today, accessed April 26, 2019, http://www.psychologytoday.com/blog/the-human-equation/201210/black-widows-the-web.
} 
Cosmopolitan magazine claims that it causes premature aging and wrinkles, and she hates getting blood on her clothes. She dislikes using a (phallic) gun to kill her targets, opting instead for more indirect (feminine) methods of killing via poisoning, drugging, and lethal injection. Using a gun, apparently, can also be detrimental to a nice manicure:

LUCY: I am Miss Nice-Nice, boopsie.[...] No more guns, not for me. The ringing in my ears keeps me up nights and, frankly, I broke a nail pulling the triggerABBY: (Overlap) You gotta be kidding me.

LUCY: - which was the proverbial straw that broke the proverbial camel's back. If you didn't bite your nails, you'd have lovely hands. Abby, this is how I feel. Cold calculation is barbaric and doesn't suit me quite the way it suits our associates, namely, Baxter. ${ }^{19}$

Although Lucy and Abby attribute her choice of weapons as an indication of "nice" (a "feminine" trait), rather than cold and barbaric (masculine) methods, her motives are entirely selfish and chillingly superficial. Lucy is hyperaware of beauty and appearance, which she remarks on frequently. She switches to lethal injection to "preserve her manicure," but Lucy's method of murder falls more closely in line with real women murderers. According to criminologists James Alan Fox and Emma E. Fridel,

Whereas both sexes employ firearms most often because of their accuracy and lethality, men tend to rely on guns more so than women... Women often prefer more distant and cleaner means of committing murder. In fact, women are responsible for nearly $40 \%$ of homicides involving poison, drugs, drowning, and asphyxiation. $^{20}$

By using drugs as her murder method, Lucy avoids the "barbarism" of gun violence but is still effective at her job, employing methods which might be described as more coldly calculating than a shot to the head.

\footnotetext{
${ }^{19}$ Wegrzyn, Killing Women, 6.

${ }^{20}$ Fox and Fridel, "Gender Differences in Patterns and Trends in U.S. Homicide, 1976-2015," 40.
} 
Lucy stresses the importance of her feminine performance as the most effective method to do her job. When Gwen prepares to take out her first "hit," she makes the mistake of introducing Abby and Lucy to the target. Cautioning Gwen about raising suspicion, Lucy states:

LUCY: We're faceless beauties in this world, Gwen. [...] It's part of our appeal in the business unless, of course, you let on that you're more than your parts. Then, of course, you become less affective. [sic] You see, Gwen, our reason d'etre is to first and foremost be unsuspected as a threat. ${ }^{21}$

Lucy suggests that the best form of safety is in the feminine gender performance because then the potential "hits" let down their guard, making them easier targets. Lucy points directly at the fact that society views women as less threatening and less likely to commit murder as the best cover for becoming a hitwoman. In this case, Lucy's feminine gender performance, highlighted here as performance, and as conscious strategy, becomes a desirable asset. Abby challenges Lucy on this in a heated exchange:

ABBY: Had I been you? His dick would have been in my mouth after dinner and a movie. (To GWEN) Don't date the prey. It's inaffective [sic].

LUCY: Then Abby, if you're so affective, how come the promotion is going to Wyatt? Hm? [...]

ABBY: Look-I work my ass off. I am working my ass off right now. GWEN: I don't think sitting here drinking coffee is a lot of work. ABBY: You have no idea. I'm not setting off any fire alarms, but if you haven't noticed, we have the rough spot in this business.

LUCY: So you didn't get promoted because you're not a man and you're inaffective [sic] because you're not much of a woman.

(Pause)

ABBY: I don't see you getting promoted. ${ }^{22}$

When Abby contests Lucy's strategy, Lucy in return points out the flaws in Abby's strategy. While Abby tries to be "one of the boys," she inevitably fails as she will never be "man" enough to take on a leadership role in the organization. Lucy also calls into

${ }^{21}$ Wegrzyn, Killing Women, 29.

${ }^{22}$ Ibid., 30-31. 
question Abby's womanhood, and the fact that Abby does not embrace her femininity makes it difficult for Abby to be successful and promoted in the hierarchy of the crime organization.

While Abby adopts masculine traits to "fit in" and move up in the organization (and therefore disrupt her gender performance), Lucy disrupts the expectation of assimilation by leaning into her feminine traits to advance or control those around her. At one point in the play, Lucy offers to get manicures with Gwen to get Gwen to stop pointing a gun at Abby's head, using a feminine distraction of pampering and maintenance as a strategy to keep Abby alive. While just as lethal as Abby, and arguably more coldly calculating and unfeeling, Lucy's "traditionally" gendered performances of indirection, flirtation, and personal vanity serve to "cover" for her masculine acts, perhaps rendering her even more dangerous to her unsuspecting "hits."

\section{Character Gender Disruption: Gwen}

The third female assassin, Gwen, is specifically identified in relation to her performance of perhaps the quintessential feminine role - motherhood. Wegrzyn

describes her as "female, 20s — a young mother."23 Throughout the play, Gwen vacillates between masculine and feminine gender performances as she fills two generally opposed roles - mother and murderer. The first time the audience sees Gwen she shoots her husband dead with a pistol concealed in her bathrobe (masculine) and then immediately offers coffee to Abby as a hospitable gesture (feminine). In the next scene, she protests becoming part of the crime organization so she can take care of her daughter (feminine), reveals that the murder of Baxter was premeditated (masculine), holds Abby at gunpoint

${ }^{23}$ Ibid., n.p. 
to force her to leave (masculine), then runs to the bathroom to vomit because she does not "have the stomach for this job" 24 (feminine). In each scene in which Gwen appears, she swings from one end of the spectrum of gender performance to the other, a juxtaposition which ends up being the source of many of the punchlines for the play and which also highlights gender as performance, and a highly unstable one. These swings often result in violence, which will be discussed later in this chapter.

\section{Character Gender Disruption: Mike Sanders}

Mike Sanders is described as "male, $30 \mathrm{~s}$ - a co-worker" in the dramatis personae of Killing Women. ${ }^{25}$ His name is a diminutive of the Hebrew Michael, meaning "Who is like God.?"26 and Sanders, his last name, is derived from Sander, a shortened form of Alexander. ${ }^{27}$ His name serves as a point of irony, as his name evokes godlike and heroic masculine icons like Alexander the Great, but he often fails to live up to these masculine expectations. While he is a hitman within the context of the play, the audience never sees him complete a hit. When Abby calls to ask Mike to babysit Gwen's daughter, he recites haiku poetry he has written about laundry (both poetry and laundry associated with femininity), which may be a misguided attempt to woo Abby. This feminine performance is continued in Scene Five. Mike approaches Abby while she is dragging Johnny Duke's body to a dumpster and confesses that he has lost his lucky bullet named Harriet (a phallic symbol with a feminine name) and bursts into tears. Mike's character

\footnotetext{
${ }^{24}$ Ibid., 23.

25 Ibid., n.p.

26 "Meaning, Origin and History of the Name Michael - Behind the Name," accessed April 5, 2019, https://www.behindthename.com/name/michael.

27 "Sander Name Meaning \& Sander Family History at Ancestry.Com,” accessed April 5, 2019, https://www.ancestry.com/name-origin?surname=sander.
} 
performance is one of support and empathy, and he repeatedly proclaims his affections for Abby, all adding to his unstable gender performance.

\section{Character Gender Disruption: Ramone}

Of all the characters in the play, Ramone exhibits the most traditionally and consistently masculine of gender performances. Ramone is a Spanish derivative of the name Raymond, meaning "wise protector," which seems ironic as Ramone fills the stereotypical role of the mob boss. ${ }^{28}$ His character description lists him as "male, $50 \mathrm{~s}-$ the boss, ${ }^{29}$ indicating that his status within the organization is his most important attribute. As Baris Cayli argues, "masculinity, or rather the performance of this, is one of the constitutive powers of [mafia] domination and the accumulation of power." ${ }^{30}$ At several points throughout the play, Ramone performs this masculinity by asserting that he is the boss and his word is law. These actions reflect the hierarchical dynamics of organized crime in life, as sociologist Maurizio Catino states, "For the mafia, the importance of the (mafia) family outweighs that of the single individual. Should a mafioso [linguistically male term] find himself in a difficult situation, even one of extreme urgency, he must still put the organization's interests first." ${ }^{31}$ Ramone's power and masculinity are preserved to the extent that he is able to preserve and control the crime organization, which thus reinforces his masculine gender performance. If anyone attempts to step out of line or challenge Ramone, the consequences are death. Ramone's

\footnotetext{
${ }^{28}$ Mike Campbell, "Meaning, Origin and History of the Name Raymond," Behind the Name, accessed April 5, 2019, https://www.behindthename.com/name/raymond.

${ }^{29}$ Wegrzyn, Killing Women.

${ }^{30}$ Cayli, "Performance Matters More than Masculinity: Violence, Gender Dynamics and Mafia Women," 37.

${ }^{31}$ Catino, "Mafia Rules. The Role of Criminal Codes in Mafia Organizations," 542.
} 
performance of hypermasculinity is exaggerated as an embodiment of the intensely sexist structure that the women struggle against. He embodies the personality triad of hypermasculinity created by psychologists Donald L. Mosher and Mark Sirkin of “(a) Calloused Sex Attitudes, (b) Violence as Manly, and (c) Danger as Exciting." ${ }^{32}$ In addition, Ramone is an alcoholic, mixing a bottle of Mylanta with whiskey to alleviate his ulcer pain. According to Mosher and Sirkin, "the macho personality pattern was significantly correlated with the frequency of use of alcohol, stimulants, depressants, marijuana, and hashish." ${ }^{, 33}$ From this comic choice of mixing a heartburn relief medication, with whiskey, a "manly" alcoholic drink, Ramone’s hypermasculine performance becomes subversive because it is so over the top. When any of the hitwomen attempt to counter Ramone's gender performance, they communicate exasperation at the absurdity of Ramone's illogical, irrational decision making (coded hypermasculine), which reinforces that the sexist workplace structure (and its leader) are absurd in and of themselves. By the end of the play, Ramone has fired Abby and promoted Gwen to Abby's now vacant position. The women in the play do not break through the glass ceiling of the syndicate, as Wyatt is still slated to take over the organization, and the masculine-dominant structure of the organization is maintained by replacing one woman with another.

\section{Character Gender Disruption: Joe Lunchbox/Johnny Duke/Baxter}

Both Joe Lunchbox and Johnny Duke are described as "a hit," Cooper is described as "insomniac med student," and Baxter is described as "Gwen's husband."34

\footnotetext{
${ }^{32}$ Mosher and Sirkin, "Measuring a Macho Personality Constellation," 160.

${ }^{33}$ Ibid., 156.

${ }^{34}$ Wegrzyn, Killing Women, n.p.
} 
Three of these characters - Joe Lunchbox, Johnny Duke, and Baxter-are all criminals that interact with the crime organization in some way, and all three die by the time their individual scenes are over. Baxter is killed by Gwen, who later becomes a member of the organization, and Johnny Duke and Joe Lunchbox are victims of the crime organization.

All three conform to traditional masculine gender performances, with Baxter and Johnny Duke exhibiting the most misogynistic attitudes of the three. As all three of these men are killed by women within the play, their hypermasculinity is challenged by the feminine characters in individualized gender disruptions that end in the characters losing their lives. These deaths symbolize the women triumphing over the hits' sexist, gendered attitudes as the women "silence" the men through death.

\section{Onstage Violence in Killing Women}

All the violence in Killing Women is tied to the operations of the crime organization. Predominantly, the violence is with guns. In the six instances during which a gun is drawn on a character, however, only one of them ends with someone pulling the trigger. This circumstance may be tied to the functions and operations of organized crime operations, particularly when addressing personnel within the crime organization. As Catino argues in his article "Mafia rules. The role of criminal codes in organizations," the mafia encounters personnel issues that can destabilize the organization:

Mafia organizations have to solve many critical organizational problems. Some of these are typical only of criminal organizations, while others are common to all organizations...As extra-legal organizations, they have information, communication, and trust problems; they have high transaction costs, have difficulties in finding reliable people, cannot keep meticulous books and records, and suffer from adverse selection in recruiting people. ${ }^{35}$

\footnotetext{
${ }^{35}$ Catino, "Mafia Rules. The Role of Criminal Codes in Mafia Organizations," 537.
} 
Most of the threatened gun violence within the play is directed at members of the crime organization, which, if the acts were completed and successful, could destabilize the crime organization, eventually leading to the crumbling of the network. For Killing Women, and especially in organized crime culture, the threat of violence seems to be as effective as the completion of violence, making these moments of threatened lethal violence worthy of examination.

The first instance of violence that happens within the play occurs in the prologue and is the only instance of completed gun violence within the play. Gwen is waiting up for her husband Baxter when he returns home with Abby. Gwen asks Baxter what Abby is doing there, and he attempts unsuccessfully to divert the conversation. Abby, attempting to break the awkward tension, proceeds to tell a wholly inappropriate sexist joke:

ABBY: [...]"Okay dad, so what's a 'bitch'?"

So the dad says, he says: "Everything outside that circle."

(BAXTER laughs. GWEN pulls a gun out of her robe and shoots him.) GWEN: Would you like some coffee? ${ }^{36}$

In this moment, two feminine characters enact masculine performances. Abby, attempting to lighten the mood, tells a misogynistic joke to break tension. This joke throws her gender performance to highly masculine as she is degrading women to break tension. In response to this joke, and to Baxter's laughing at it, Gwen pulls out a gun from her robe and shoots Baxter. Because Baxter is complying with the misogyny and laughing at the remark, Gwen uses a phallic symbol, a gun, to end his life. This gender performance is immediately disrupted when Gwen offers Abby coffee, performing feminine hospitality in the aftermath of her violent masculine act.

\footnotetext{
${ }^{36}$ Wegrzyn, Killing Women, 2.
} 
The only other instance of completed violence in the play happens in Scene One. Lucy has fallen in love with her hit, Joe Lunchbox, and he has arrived at her apartment two hours prior to their scheduled date to confess his love for her. Abby shows up unexpectedly to ask Lucy how to deal with Gwen following Gwen's murder of Baxter. While they are talking, Abby makes Joe a laced drink, which causes him to become intoxicated and less resistant to Lucy. Lucy draws up a solution in some hypodermic needles, and then asks Joe to dance. As they dance, the following occurs:

JOE: You're beautiful. Good dancer. Nicer if we had some music. Some jazz, slow jazz, with a heavy bass, something beautiful. So beautiful.

(LUCY searches out a vein in his neck as they dance. She slides the needle into a vein. Sensual for both. ABBY exits. Lights. $)^{37}$

This instance of violence differs markedly from the rest of the violence that is seen within Killing Women. First and foremost, the methodology is more in line with how women tend to commit murder in real life. According to criminologist James Alan Fox and Emma E. Friedel, "Women often prefer more distant and cleaner means of committing murder. In fact, women are responsible for nearly $40 \%$ of homicides involving poison, drugs, drowning, and asphyxiation. ${ }^{38}$ Lucy is using a drug or poison to disorient her victim, and then uses a hypodermic needle to inject a lethal concoction into him. This moment also is highly romanticized, as Lucy is dancing with Joe as she kills him; this mood is reinforced by the stage direction "Sensual for both." 39 This moment could also be read as an act of mercy, as Lucy prefers this less painful method of killing her victims than the gorier, bloodier, and more painful gunshot wound. In a very interesting way, however, Lucy's method mirrors Gwen's appropriation of symbolic masculinity using a

\footnotetext{
${ }^{37}$ Ibid., 7.

${ }^{38}$ Fox and Fridel, "Gender Differences in Patterns and Trends in U.S. Homicide, 1976-2015," 40.

${ }^{39}$ Wegrzyn, Killing Women, 7.
} 
phallus-shaped weapon. Lucy uses a needle and injection, which semiotically can be connected to the phallus and ejaculation. This makes Lucy's murder an act that juxtaposes masculine and feminine codes, a destabilizing image that seems in keeping with her generally unstable gender identity.

The remainder of the acts of violence in Killing Women are threatened acts of violence with guns. The first occurs after Abby has been calling other members of the organization to find someone to babysit Gwen's daughter while Abby trains Gwen to take out a major hit. As Abby talks to Lucy on the phone, Gwen sees an open opportunity to assert her dominance:

ABBY: Are you busy tomorrow morning? (GWEN will raise her gun, unnoticed by ABBY.)

LUCY: Why?

ABBY: I need you to baby-sit.

LUCY: A child?

ABBY: No, a llama—of course a child. Gwen's daughter.

LUCY: She's adorable, isn't she?

ABBY: Eh.

LUCY: I'm glad Gwen's daughter doesn't look anything like Baxter; I always thought that he looked like one of those rare, wrinkly dogs inbred for their weirdness. I'm not suggesting that a relationship should be founded on aesthetics. ABBY: What the fuck are you talking ab - can you baby-sit or what? LUCY: I'm awfully busy busy busy. When do you need me to baby-sit? (GWEN put the gun to ABBY's head, clicks off the safety. GWEN is stone-cold scary in kill mode.)

GWEN: He wouldn't listen to me either. What I said never mattered, ever, not ever, not at all. If I wanted him to listen, I'd have to make him listen. If this is the language he understood, then it's the language I would speak. The night before, I took all of Tess's pictures and art off the refrigerator so they wouldn't get sprayed with blood. He heard me loud and clear. (Pause) My daughter shouldn't see me like this. ${ }^{40}$

Gwen is an opportunistic killer and is highly strategic - like Lucy, her actions exhibit jarring juxtapositions of feminine-coded performances of ineptitude and motherhood with

${ }^{40}$ Ibid., 20. 
masculine-coded, premeditated brutality and violence. The destabilized gendered performances create a cognitive dissonance for the audience to process, which may result in these moments reading as comedic. Wegrzyn even indicates this with her stage directions, indicating that Gwen is "stone-cold scary in kill mode." When in this mode, Gwen reveals that murdering Baxter was entirely premeditated; she removed her daughter's art to prevent blood spatter getting on them (and, consequentially, residual evidence of the crime on them). She knows that this behavior is unacceptable to the gender norms and gender performance she regularly exhibits, and she acknowledges that her daughter should not see her in this state. By doing so, Gwen is acknowledging that her gender performance is not in alignment with normative gender performance.

The next instance in Killing Women when gun violence is threatened occurs when Abby threatens to kill Cooper. Both Gwen and Lucy refuse to kill him as he is an innocent bystander and Lucy's lover, so Abby takes matters into her own hands:

\section{(ABBY aims gun at COOPER.)}

COOPER: Woah!

LUCY: Abby, put it down.

ABBY: Do you think I like cleaning up your messes, covering for you. Do you think I wake up saying, gee, I wonder how I can make Lucy hate me today. LUCY: Okay, Abby, you have made your point. But Cooper doesn't have any business with Ramone, he's just a guy across the street.

COOPER: I'm just a guy.

LUCY: He came to protect Gwen, an act of kindness.

COOPER: I'm a nice guy.

LUCY: And he is now just in the wrong place at the wrong time.

COOPER: My timing sucks.

LUCY: Now, Abby, I think you need to prioritize your anger before you mismanage your emotional resources, yes?

ABBY: What?

LUCY: Please don't point your boom stick at us.

(ABBY lowers the gun. $)^{41}$

${ }^{41}$ Ibid., 57-58. 
This is the first time that the audience sees Abby, the protagonist who is lauded as the best and most experienced hitwoman in the group, nearly kill someone. In this moment, the audience sees her frustration with Lucy as she has covered for Lucy and tried to correct Lucy several times throughout the play on mafia protocol. Now, Abby is given the added burden of cleaning up after Gwen's mistakes as well, causing Abby to reach a breaking point. Abby says very little in this exchange and lets her physicality, coded masculine, do the talking. By keeping Cooper at gunpoint, Lucy and Cooper then have to talk Abby down as they know Abby has the upper hand in this scenario-she already has the gun pointed at Cooper, and she is more experienced with guns than both of them. Lucy also plays a role in this by asking Abby to "code switch" from masculine to feminine by acting more logical (masculine) rather than overly emotional (feminine). Lucy also uses coded language for the gun, referring to it as a "boom stick," which is a euphemism of guns that codes masculine because it is a lengthy stick-shaped weapon that explodes out of the end (like an ejaculating phallus). Because of this, Abby has no need to use words to assert dominance; she already has it. In the end, she chooses to lower the gun. This could be read as an act of mercy (coded feminine) or a deliberate, strategic choice not to kill (coded masculine). Which version might dominate could be influenced by the staging of the moment, and the actor's choices, but likely her decision not to kill Cooper would retain some ambiguity, underscoring the instability of her gender performance.

The final instance of threatened gun violence is a standoff-turned-mutiny between the members of the crime organization, Gwen, and Ramone. Ramone has instructed Abby to kill Gwen after incentivizing her with a promotion: 
RAMONE: Funny that Abby didn't enlighten me sooner. Very very interesting. Well now. Abby. Why don't you go on and finish up Wyatt's job here, and we'll see what we can do about your promotion.

(ABBY pulls her gun out and puts it to GWEN's head. Pause.)

ABBY: Fuck! FUCK!

RAMONE: Something the matter, Abby?

ABBY: No. I'm fine!

RAMONE: Then can we get back to business here.

ABBY: Yeah! Hold on. Give me a second.

RAMONE: It's getting late.

ABBY: Give me one second. One second. Give me one second. (Puts the gun to GWEN's head. Pause. She lowers the gun.)

RAMONE: Mike, you're going to have to finish Abby's job here.

(MIKE nods. Puts his gun to GWEN's head.)

MIKE: Um.

RAMONE: What?

(MIKE lowers the gun.)

MIKE: I like Abby. I like Abby a whole lot. I've liked her ever since I first set my eyes on her and she said, "What are you looking at, slackjaw?" We have an ice cream date. I don't want to muck this up by shooting one of her friends in the head. That's the quickest way to muck up a first date.

(RAMONE looks to ABBY for confirmation.)

ABBY: We're having ice cream.

RAMONE: This is ridiculous. You want a job done right, you have to do it yourself.

(RAMONE is about to go for his gun, but GWEN puts her gun to RAMONE's

head. Pause.)

RAMONE: Did Wyatt make you play Monopoly?

GWEN: Yes.

RAMONE: Did you beat him at Monopoly?

GWEN: Yes.

RAMONE: I told him, one of these days someone was going to beat him. [...]

GWEN: Completely overrated.

RAMONE: Exactly.

GWEN: Exactly.

(GWEN lowers her gun. Pause. $)^{42}$

This sequence of events is a complex one, with multiple players involved in making the same level of threatened violence. When Abby first puts the gun to Gwen's head, she does so without a word. Realizing what she is being asked to do, she stops and is then pressured by Ramone to go through with killing Gwen. When Abby lowers her gun,

\footnotetext{
${ }^{42}$ Ibid., 70-71.
} 
Ramone sticks to mafia protocol and instructs Mike to do the killing. In other words, Ramone asks Mike, a man, to finish a man's job. Mike then upsets this gendered expectation by stating he cannot kill Gwen as it may ruin his romantic chances with Abby. When Mike is unable to do the killing, Ramone attempts to take matters into his own hands. This attempt by Ramone to draw a gun on Abby falls in line with Catino's earlier observations that the mafioso put the organization above the needs of individuals, which, in this case, means that Gwen must die. ${ }^{43}$ Each time the gun is raised in this sequence, the holder of the gun wields power coded masculine as he or she is threatening Gwen at gunpoint with a phallic weapon. When both Abby and Mike lower their weapons, their performance transforms from masculine to feminine as they are unable to complete the act of murder; in other words, this phallic masculine gesture becomes feminine through impotency. Out of the three attempts to kill Gwen, Ramone's becomes most feminized as he is unable to draw his gun to point it at Gwen before Gwen usurps Ramone and puts him at gunpoint. When Gwen lowers the gun pointed at Ramone, it is a choice rather than a moment of feminine weakness not to kill Ramone but to let him go free. In exchange, Ramone rewards Gwen by hiring her, firing Abby, and giving Gwen Abby’s job. Because Gwen “out-manned” Ramone by drawing her gun first, Ramone respects Gwen's masculine gender performance but fires Abby for her feminine emotionality. The masculine hierarchy of the crime organization is maintained, and Abby, seeking direction with her newfound freedom, goes "back to school" for Gwen's daughter's career day in search of a new path forward.

\section{Conclusion}

${ }^{43}$ Catino, "Mafia Rules. The Role of Criminal Codes in Mafia Organizations," 542. 
Joan Acker's theory of gendered organizations argues that while organizations have been researched and treated as gender-neutral, the reality is that organizations are created and structured for a man's world. Women are forced to assimilate to the masculine to advance in the workplace, which is an enormous and inequitable task. ${ }^{44}$ Killing Women directly depicts and satirizes this feminist struggle in the workforce by using crime organizations as a lens to demonstrate the double standards that women and mothers are held to. Wegrzyn uses organized crime, a highly masculine, hierarchical structure with a highly masculine culture, as a place where women appear to have "broken through" to be a part of, but in the end, they still cannot break through the glass ceiling to leadership roles, even if the women are the best at their jobs. The crime organization in Killing Women serves as a metaphor for society and corporate America at large; even though women have broken through many different industries and have gained a solid foothold in the workforce, the glass ceiling to leadership still exists and seems impenetrable. In a sense, this play suggests that contemporary society at large is a criminal organization-hierarchal, misogynistic, and sexist.

Abby, the protagonist of the play, defies gender expectations as a professional hitwoman. She is the best at her job, but even being the best at a "man's" job does not save her from facing sexist discrimination. Abby sees no recognition or reward and is passed over by a less qualified, newer male colleague for promotion. Abby's inability to maintain her masculine gender performance by not being able to kill Gwen costs Abby her job and forces Abby to try to find a new identity at the end of the play.

\footnotetext{
${ }^{44}$ Acker, "Hierarchies, Jobs, Bodies: A Theory of Gendered Organizations."
} 
Abby also forces Gwen to choose between motherhood and murderer, like the choices many women face between being a stay-at-home parent and staying or joining the workforce. Even though Gwen is the "best shot" out of all the members of the crime organization, she does not want to join it because she wants to be a good mother to Tess. For Gwen, it would be impossible for her to be both a good mother and a great employee. This tension is faced by many women in the workforce who feel pulled between two opposing yet equally important worlds - if women devote themselves to their work, they are abandoning their children, and if they devote themselves to their children, they are not fulfilling their potential to contribute to society outside the home, or to their own personal, economic, or professional fulfillment. The violence within Killing Women serves as a reminder to the audience of the lethal repercussions of a hierarchal and unfairly gendered society, in which, as Acker has argued, the ideal worker is male, and women and all things associated with women - "pregnancy, child care, menstruation, and mythic 'emotionality' — are suspect, stigmatized, and used as grounds for control and exclusion. $" 45$

Wegrzyn's use of humor (such as Abby regaining consciousness at the start of the second act with a moustache drawn on her face by Tess) is part of her subversive strategy. American Studies professor Rebecca Krefting argues that humor provides a unique opportunity for political disruption in her monograph All Joking Aside: American

\section{Humor and Its Discontents:}

The promise and potential of comedy is that its progenitors can and do make social critiques; therefore, it is important to note that many women strive to incorporate appraisals of patriarchy, gender norms and stereotypes, capitalism,

${ }^{45}$ Ibid., 152. 
and bigotry into their comic performances...Humor that foregrounds one's marginality in a way that challenges stereotypes and illumines the history and consequences of one's exclusion disrupts the illusions of American claims to democracy and meritocracy. This is, perhaps, unsettling for privileged viewers occupying dominant categories of identity, but audience members sharing a similar history of exclusion, scapegoating, and exploitation may be compelled to identify... ${ }^{46}$

At the end of the play, Abby visits Gail's children's school on Career Day and offers the children this advice:

ABBY: [...] Here's my official Career Day advice. You're all going to grow up and get job, right? Some of you will hate your jobs, some of you won't really care, the lucky ones will like their jobs. You may get fired. No matter how good of a job you do, you might get fired for bullshit reasons... ${ }^{47}$

Abby's advice is more of a warning than actual advice. Without singling out gender directly, Abby's warning resonates with the feminist themes of the play that no matter what the women in the play did, it was not enough to take over leadership, and the reason that Abby was fired was her refusal to end the life of another woman. Yet Abby closes the play on a more hopeful note by reading a story written by Tess entitled Princess Tess and the Moon Monsters. In the story, Princess Tess loved to watch the moon change, but she notices one night that the moon stops changing. Abby continues the story: "So the princess climbed into her rocket-ship, and blasted off to the moon because someone had to do something. And the princess could do anything. Anything at all. She could even fix the moon. ${ }^{48}$ "' This final story serves as a call-to-arms from Wegrzyn. Women must do something because women can do anything, and nothing will change if women do not take action.

\footnotetext{
${ }^{46}$ Krefting,All Joking Aside: American Humor and Its Discontents, 128.

${ }^{47}$ Wegrzyn, Killing Women, 79.

${ }^{48}$ Ibid., 79-80.
} 


\section{CHAPTER FIVE \\ The Butcher of Baraboo: "Lots of ways to kill a person..."}

\section{Introduction}

After discovering Wegrzyn's Killing Women, I felt compelled to explore other works by her to see whether her other plays included similar amounts of violence committed by women. The Butcher of Baraboo delivers. I was sucked in by the complex family tree, the intrigue, and the seemingly bizarre women characters that collide throughout the play. With depictions of various forms of violence from butchery to stabbing, to face slams, The Butcher of Baraboo proved to be particularly apt for analysis in this dissertation.

The Butcher of Baraboo was commissioned and originally produced by Steppenwolf Theatre Company as part of their First Look Repertory of New Work in the summer of 2006. ${ }^{1}$ In The Butcher of Baraboo, Wegrzyn has created a complex family structure akin to Tracy Letts' August: Osage County, with a distinctly Midwestern bent. The play tackles the issues of abortion rights, conservative values, the roles of women in the domestic and professional sphere, and the ways that women transgress maledominated workforces to survive. In this chapter, I will examine how the gender performances of the characters within The Butcher of Baraboo align with or divert from current understandings of womanhood and femininity in the domestic and professional spheres, giving particular attention to women in male-dominated careers.

\footnotetext{
${ }^{1}$ Marisa Wegrzyn, The Butcher of Baraboo (New York: Broadway Play Publishing Inc., 2015).
} 


\section{Summary of The Butcher of Baraboo}

The entirety of The Butcher of Baraboo takes place in the kitchen and living room of Valerie's home in Baraboo, Wisconsin, in February of an unnamed year (presumably the present). Valerie's husband Frank has been missing for about a year, and many in the town assume that Valerie had something to do with his disappearance. Valerie, a butcher by trade, lives with her daughter, Midge, a pharmacist who steals drugs from the pharmacy and sells them to middle schoolers. Valerie's sister-in-law Gail, a police officer and D.A.R.E. program coordinator, suspects that Valerie and Midge had something to do with the disappearance but has no evidence or leads to pursue. Frank's brother, Donal, moves in next door to Valerie with his wife, Sevenly, who has recently discovered she is pregnant with her seventh child. Over a family dinner, all the characters reminisce about Frank on the anniversary of his disappearance. As the family members begin to trickle home or to their respective bedrooms, Valerie and Donal share a hug, indicating to the audience that their relationship has been more than familial. Sevenly returns in the middle of the night to retrieve her brownie pan and discovers Midge up waiting for her. Midge and Sevenly discuss the possibility of Midge providing Sevenly access to RU-486, the medical abortion pill. When Valerie discovers the plot to terminate Sevenly's pregnancy, she informs Donal of the plan. Donal threatens Midge and offers to pay her off if she agrees to leave Baraboo forever. Midge in turn confronts Donal with her suspicion that he, not Frank, is her biological father. Donal avoids the question and poses his own regarding Midge's possible involvement in Frank's death, as she was the last person to see him alive. Midge offers to take Donal to where she last saw Frank, and Donal decides to go with her. Unbeknownst to Donal, Midge takes Valerie's prized meat cleaver with 
her as she walks out the door. The next morning, Valerie confronts Midge over a new ding in her meat cleaver, and after a tense exchange, Midge reveals that she used it the day before when she took Donal out to the woods. Valerie strikes Midge with a coffee mug and slams her face into the butcher block until Midge is unconscious. As Valerie begins to hogtie her, Sevenly enters looking for Donal. Valerie reveals that Midge knows where Donal is, and leaves Sevenly with the task of watching her. When Midge regains consciousness, she convinces Sevenly to untie her, but Sevenly is unable to do so before Valerie returns. Valerie raises her meat cleaver to behead Midge for killing both Frank and Donal when Donal bursts through the door, freezing and covered in frostbite. Sevenly is leaving to take Donal home when Gail enters. Gail unties Midge, then stabs Valerie for killing Frank. Gail insists that this wound will not kill Valerie, it will just serve as a major pain and inconvenience, and then leaves. At the end of the play, Midge reveals to Valerie what actually happened to Frank - that she watched him walk off into the night, never to return. Upon hearing the 'truth' at last, Valerie takes responsibility for her husband's death but shows no remorse, observing "Lots of ways to kill a person, no death worse than a heartbreak to drive them away ... I am guilty. And I'm going to get away with it."

\section{Character Gender Disruption: Valerie}

Interestingly, Butcher is the second play in this study to feature a protagonist named Valerie. Like Valerie from That Pretty Pretty; or, The Rape Play, Valerie in The Butcher of Baraboo reveals the "strong, healthy"2 meaning of the name as she repeatedly

\footnotetext{
2 "Valerie Name Meaning \& Origin."
} 
displays her physical strength by slamming the meat cleaver into her butcher block in the kitchen. In the dramatis personae, Valerie is described as "female, 50s. A butcher."3 Women butchers are a rarity, and to my knowledge, there is only one scholarly resource examining women butchers in detail. In their essay "Women and butchery: some cultural taboos" published in 1993, sociologist Rosemary Pringle and social work research fellow Susan Collings argue that "Despite all the efforts to encourage women into nontraditional trades, to become electricians and plumbers, car mechanics and carpenters, butchering has been ignored and the 'woman butcher' is almost unthinkable as a cultural category."4 As a woman butcher, Valerie is already a gender outlaw simply due to her occupation. Pringle and Collings continue:

The popular representation of the female butcher is trapped within the masculine confines of the occupation itself. This necessary contradiction (woman-butcher) can only be tolerated if it is recast in the conventional gender binarism which it unquestionably subverts. Femininity, it seems, has no place inside the apron. An 'appropriate' woman butcher must relinquish any claim to feminine identity. ${ }^{5}$

Because Valerie is described in the dramatis personae only as "a butcher" and not "Midge's mother" "Frank's widow," or any other description of the character that might establish a "claim to feminine identity" other than identifying her biological sex as "female," Wegrzyn may very well be guiding the audience towards viewing Valerie as "masculine". Her character displays other traits that may be coded as masculine. She has little tolerance for any challenges to her will, and she reacts to such challenges with violence at several points throughout the play. When Midge prepares to dump Starbucks

\footnotetext{
${ }^{3}$ Wegrzyn, The Butcher of Baraboo, n.p.

4 Pringle and Collings, "Women and Butchery," 30.

${ }^{5}$ Ibid., 40.
} 
premium roast coffee into Valerie's decaf Maxwell House coffee container, Valerie

threatens to chop off Midge's hand:

VALERIE: Mess up my coffee again and yeah you can guess how many chops it takes my meat cleaver to chop your hand clean off [...] You know I don't drink caffeine.

MIDGE: You do now.

(VALERIE takes the coffee bag, picks up her meat cleaver, slams the Starbucks on the butcher block, and cleaves the Starbucks with her meat cleaver.)

MIDGE: (Smoldering) That is Fair Trade Coffee. [...] It is very expensive. That particular bag I got for free. But normally it's twelve dollars a pound, plus tax, so thirteen dollars about.

VALERIE: Well, it's half off now. ${ }^{6}$

By slashing the Starbucks coffee (which, coincidentally, has a logo of a female mermaid smiling on it) with a meat cleaver, Valerie performs a distinctly masculine gesture. This is part of the performance of butchery that often skews masculine. Pringle and Collings add:

Butchers have not only a masculine but also a sinister presence: they work at the boundaries of life and death, of human and animal, of bodies and carcasses. Culturally these areas of ambiguity and transition evoke fascination and horror, signifying both desire and the dissolution of the subject. The unity of the body is constructed by the exclusion of impure matter, which it regards as other. ${ }^{7}$

This association of butchery with being "at the boundaries of life and death" may be partially responsible for rumors to spread throughout Baraboo regarding Valerie's involvement with Frank's disappearance. It is also an association that heightens the abject nature of the profession. According to feminist psychoanalyst Julia Kristeva, who theorized the abject as the quintessential "Other", radically excluded from yet perpetually challenging that from which it is expelled.

\footnotetext{
${ }^{6}$ Wegrzyn, The Butcher of Baraboo, 2-3.

${ }^{7}$ Pringle and Collings, "Women and Butchery," 30.
} 
Kristeva's theory of Abjection has its roots in Mary Douglas' Purity and Danger: An Analysis of the Concepts of Pollution and Taboo. According to Douglas, "We should expect the orifices of the body to symbolise its specially vulnerable points. Matter issuing from them is marginal stuff of the most obvious kind. Spittle, blood, milk, urine, faeces or tears by simply issuing forth have traversed the boundary of the body." ${ }^{8}$ For Kristeva, these bodily emissions are included in these abject associations as they cross the border from inside the body to the outside of the body. In Kristevan terms, the abject "disturbs identity, system, order. What does not respect borders, positions, rules. The in-between, the ambiguous, the composite." Anything that threatens borders or rules can be deemed "abject." As anthropologist Robert Phillips puts it,

Abjection refers to the vague sense of horror that permeates the boundary between the self and the other. In a broader sense, the term refers to the process by which identificatory regimes exclude subjects that they render unintelligible or beyond classification. As such, the abjection of others serves to maintain or reinforce boundaries that are threatened. ${ }^{10}$

These abjections have also been connected to womanhood, as other feminist theorists

(such as Judith Butler and Barbara Creed) have connected abjection to womanhood.

Feminist scholar Megan Karius argues in her essay "Understanding Abjection: An

Analysis of the Monstrous-Feminine in the Art of Cindy Sherman:"

The female body is reviled as abject, for men and women. Women are taught to internalize self-hatred and shame of our bodily functions, such as breast-feeding, giving birth, and especially menstruation. The abject female body must be covered, hidden, and disguised by traditional modes of femininity. Woman is still Other, but her abjection is concealed. ${ }^{11}$

\footnotetext{
${ }^{8}$ Mary Douglas, Purity and Danger: An Analysis of the Concepts of Pollution and Taboo (London: Routledge, 1966), 122.

${ }^{9}$ Kristeva, Powers of Horror, 4.

${ }^{10}$ Robert Phillips, “Abjection,” TSQ: Transgender Studies Quarterly 1, no. 1-2 (May 1, 2014): 19.

${ }^{11}$ Megan Karius, "Understanding Abjection: An Analysis of the Monstrous-Feminine in the Art of Cindy Sherman," MK Feminist, December 31, 2011, accessed April 30, 2019, http://megankarius.com/academicpapers/abjection-cindy-sherman/.
} 
Valerie also follows a particularly abject occupation — butchers sever the boundary of the skin of flesh from the body and make the internal (blood, muscle, bone, organs) cross the border to the external. Moreover, the butcher's role is to transform living creatures into dead ones, thus violating the boundary of life and death. That Valerie is suspected of her husband's death is another abject association. According to Kristeva, "Any crime, because it draws attention to the fragility of the law, is abject, but premeditated crime, cunning murder, hypocritical revenge are even more so because they heighten the display of such fragility." 12 As a woman butcher suspected of her husband's murder, working on a daily basis to separate and categorize what is object and what is offal Valerie is abject determining abject. Valerie's abjection extends into the town of Baraboo at large as she remarks she has fewer customers coming to her shop and that the town has been gossiping about her alleged involvement in Frank's disappearance. She has been "cast out" of her society for actions she did not do, furthering her abjection.

In addition to following a highly masculine career, Valerie holds highly conservative views. She is pro-life, which proves to be an interesting and bizarre choice considering her career is focused on ending the lives of animals. This mindset could reflect the culture of Baraboo, Wisconsin, a small town of about twelve thousand people, ninety-four percent white according to the most recent census data. ${ }^{13}$ In November of 2018, a photo of male high school students of Baraboo High School apparently holding

\footnotetext{
${ }^{12}$ Kristeva, Powers of Horror, 4.

13 "U.S. Census Bureau QuickFacts: Baraboo City, Wisconsin," accessed September 16, 2018, https://www.census.gov/quickfacts/baraboocitywisconsin?\#qf-headnote-a.
} 
their arms in a Nazi salute went viral. ${ }^{14}$ Sociologists Michele Dillon and Sarah Savage investigated the values of rural populations regarding abortion and same sex marriage in their issue brief "Values and Religion in Rural America: Attitudes Toward Abortion and Same-Sex Relations" and discovered that the Midwest rural populations were the second most likely region to hold conservatives views. Regarding abortion, all the rural regions have majority support for abortion, but only in special circumstances such as rape or other trauma. ${ }^{15}$ With Valerie living in a rural town in the Midwest, it is more likely that she will hold anti-abortion views, making this juxtaposition of values and career path more likely. Espousing conservative views could be a part of Valerie's attempt to cross over from her abject state to one of conformity with her community. Even though Valerie's biological sex is female, even though she was a wife in a heterosexual partnership, and is a mother, her profession, and the aggressive and violent behaviors that make her a suspected killer, code masculine. This makes Valerie's gender performance an especially abject and unstable one.

\section{Character Gender Disruption: Midge}

Midge, like her mother, also evokes particularly abject associations. A shortened form of the name "Margaret," which is rooted in the Greek word for "pearl," Midge proves to be a rare gem of decency and humanity even though her methods are often misguided. On the other hand, a "midge" is a type of insect that is commonly confused

\footnotetext{
${ }^{14}$ Christina Caron, "Students Who Made Apparent Nazi Salute in Photo Won't Be Punished," The New York Times, December 11, 2018, sec. U.S., accessed April 20, 2019, https://www.nytimes.com/2018/11/24/us/baraboo-wisconsin-nazi-salute-photo.html.

${ }^{15}$ Michele Dillon and Sarah Savage, "Values and Religion in Rural America: Attitudes toward Abortion and Same-Sex Relations" (2004): 10.
} 
with mosquitoes but lacks the ability to take a blood meal. ${ }^{16}$ Midges are also sometimes referred to as "gnats" 17 and are often seen as a nuisance or pest as they tend to dwell in or near homes. ${ }^{18}$ These characteristics appear as a part of Midge's personality; rather than move out on her own, she resides at home with her mother Valerie, who treats Midge like a "pest" or "nuisance." Midge is also suspected of murder, but by the end of the play, the other characters discover that Midge never took the blood of another. In comparing Midge to an actual midge, blurring boundaries between animal and human, Wegrzyn increases this play's abject associations.

In the dramatis personae, Midge is described as "female, 32. A pharmacist. VALERIE's daughter." ${ }^{19}$ Unlike her mother, Midge is identified both in terms of her career path and her role within the family structure. As a pharmacist, Midge is a part of a historically masculine career in which women have recently gained significant footing, making up 54\% of pharmacists in the United States in $2012 .{ }^{20}$ Midge is also a criminal. To make additional money, Midge steals drugs from the pharmacy and sells them to the local middle schoolers. Criminologists Claire White, Justin Ready, and Charles M. Katz studied how prescription drugs are dealt by looking at the arrests of 366 drug offenders in Maricopa County, Arizona and discovered that those who stole the drugs from healthcare facilities (such as a hospital, pain clinic, or pharmacy) were more likely to be women in

\footnotetext{
16 "Midges," accessed April 27, 2019, https://www.insectidentification.org/insectdescription.asp?identification=Midges.

17 "Midge | Insect," Encyclopedia Britannica, accessed April 27, 2019, https://www.britannica.com/animal/midge.

18 "Midges."

${ }^{19}$ Wegrzyn, The Butcher of Baraboo, n.p.

20 "5 Professions Ruled by Women | Fortune," accessed April 27, 2019, http://fortune.com/2013/03/11/5professions-ruled-by-women/.
} 
their thirties. ${ }^{21}$ Midge matches this description, but in reality, the pharmacists themselves doubling as drug dealers seems to be a rarer phenomenon. Medical researchers Khary K. Rigg, Steven P. Kurtz, and Hilary L. Surratt noted in their study "Patterns of prescription medication diversion among drug dealers" that drug dealers are usually third party to the pharmacist and use pharmacists and pharmacy technicians as a "connect" who tips off the drug dealers regarding incoming drug shipments or turning a blind eye to fraudulent prescriptions. ${ }^{22}$ Midge's criminal activity significantly complicates her Aunt Gail's job as the school district's D.A.R.E. program officer, and it could also be extremely harmful to the pre-teens to whom she is dispensing the drugs. Midge also drugs Sevenly when Sevenly comes to her asking for help in tracking down RU-486. Midge knowingly drugs a pregnant woman, an action somewhat mitigated by her knowledge that Sevenly does not want to carry the child and is actively seeking a way to abort it. While drugging Sevenly (which, she later claims, is due to wanting to give Sevenly a chance to rest), Midge warns Sevenly against asking about contraceptives and abortion medication in Baraboo as its community is prone to gossip. To protect Sevenly's reputation, Midge offers to get the medication for Sevenly even though Midge's pharmacy does not stock it: "The manager of my pharmacy 'forgets' to stock RU-486." ${ }^{23}$ That the manager is consciously barring access to abortion points to the conservative nature of Baraboo. Midge's willingness to get RU-486 for Sevenly (presumably putting her job at risk), and

${ }^{21}$ Clair White, Justin Ready, and Charles M. Katz, "Examining How Prescription Drugs Are Illegally Obtained: Social and Ecological Predictors," Journal of Drug Issues 46, no. 1 (January 2016): 12-13. ${ }^{22}$ Khary K. Rigg, Steven P. Kurtz, and Hilary L. Surratt, "Patterns of Prescription Medication Diversion among Drug Dealers," Drugs: Education, Prevention and Policy 19, no. 2 (April 2012): 151.

${ }^{23}$ Wegrzyn, The Butcher of Baraboo, 35. 
even her willingness to provide illegal drugs to teens, marks her as an outsider, a rebel, within this conservative community, subverting customs and laws.

Midge's abject status extends to her sexual as well as her gender identity. During the play, the audience discovers that Midge is a lesbian. When she drugs Sevenly, she kisses her and asks her on a date. According to Tessa Wright, Senior Lecturer in Human Resource Management at the Centre for Research in Equality and Diversity of London, UK, "Defining women as lesbians (regardless of their actual sexual orientation) makes them less threatening to the ideologies of masculinity....as they can be perceived as 'unnatural women."”24 Defining her as an "unnatural woman," disrupts Midge's feminine gender performance because her lesbianism directly threatens the sexual role that masculine men are supposed to inhabit; therefore, there must be something "faulty" with her womanhood and her femininity. However, Wright's argument that lesbians are "less threatening to the ideologies of masculinity" seems challenged when considering that lesbians are in competition with the masculine for women's sexual attention. Midge's identity as a lesbian destabilizes her performance as feminine.

Midge's second identity marker given by Wegrzyn is that of "daughter.” By situating and solidifying this aspect of her identity before the play begins, Wegrzyn reinforces the significance of Midge's function within the family structure. Valerie is either unaware or in denial of Midge's sexuality, as she makes several remarks throughout the play indicating that Midge needs to find herself a nice man to marry and settle down with. Midge usually dismisses these comments without outing herself, which

\footnotetext{
${ }^{24}$ Wright, Gender and Sexuality in Male-Dominated Occupations: Women Working in Construction and Transport, 28.
} 
suggests that heteronormativity is part of Baraboo's and Valerie's conservative views. The idea of daughter codes as feminine as only women can be daughters, but her legitimacy as Frank's child is called into question, which destabilizes her feminine gender performance as "daughter" over the course of the play.

Through her various identities - pharmacist, thief, drug dealer, daughter, woman, and lesbian-Midge's feminine gender performance is destabilized by Wegrzyn to raise questions as to how well women can ever "fit" in any of these categories.

\section{Character Gender Disruption: Gail}

Gail's name, like that of her sister-in-law Valerie, is one that has been used and explored in other works in this study. A diminutive of Abigail, which means, in Hebrew, "my father is joyful," 25 the name seems to have less significance in this play than it did in Wegrzyn's other work, Killing Women. It is possible that Gail could connote gale force winds, as she blows in and out of scenes with a dramatic flourish. The dramatis personae positions Gail as "female, mid/late 40s. A cop. VALERIE's sister-in-law." ${ }^{26}$ Similar to that of Valerie, Gail's career, which is also a typically masculine one, comes before her position within the family structure. She is married to a man named Eddie, who is unseen in the play, but who apparently causes her considerable grief. Gail also attempts suicide at one point in the play, but her attempt is thwarted by Midge, who has put jelly beans in Gail's gun instead of bullets.

\footnotetext{
25 "Abby."

${ }^{26}$ Wegrzyn, The Butcher of Baraboo, n.p.
} 
Gail's career as a police officer serves as a significant gender disruption for the character. As Wright points out in her book Gender and Sexuality in Male-Dominated Occupations, "Women's participation in jobs traditionally said to require 'masculine' traits or attributes challenges the supposed 'naturalness' of the association of these traits with men." 27 Policing is highly associated with the masculine, as Cara E. Rabe-Hemp argues in her article "POLICEwomen or PoliceWOMEN?: Doing Gender and Police Work:"

The occupation of policing is masculine by social construction, as law enforcement is typically associated with aggressive behavior, physical strength, and solidarity (Crank, 1998; Garcia, 2003). Hegemonic masculinity in police agencies is maintained through: authority, heterosexism, the ability to display force, and the subordination of women (Connell, 1995; Connell \& Messerschmidt, 2005; Messerschmidt, 1993). ${ }^{28}$

Gail tends to perform highly masculine behaviors (sometimes underscored as "performance") when she appears in the play. In the first scene, although Gail states that she is at Valerie's house to talk to Midge about "police business" while she rests a hand on her gun in the holster, in reality she is there to see if Midge still needs a babysitter for Friday night. In this moment, Gail seems to be using her authority as a police officer to mask more feminine motivations. Many of her behaviors throughout the play also reveal the impact of Gail's police work on her personal life. Criminologist Kenneth Dowler and sociologist Bruce Arai pinpoint some of these factors in their article "Stress, gender and policing: the impact of perceived gender discrimination on symptoms of stress:"

A review of police stress research reveals that the costs of stress [for both men and women] include: cynicism and suspiciousness, emotional detachment from family, reduced efficiency, absenteeism and early retirement, excessive aggressiveness, alcoholism, marital or family problems (extramarital affairs,

\footnotetext{
${ }^{27}$ Wright, Gender and Sexuality in Male-Dominated Occupations: Women Working in Construction and Transport, 25.

${ }^{28}$ Rabe-Hemp, "POLICEwomen or PoliceWOMEN?," 116.
} 
divorce or domestic violence), post-traumatic stress disorder, health problems (heart attacks, ulcers, weight gain) and suicide (Toch, 2002, p. 6). ${ }^{29}$

Gail experiences many of these symptoms of police work stress. Without this context, however, many of her behaviors may be coded masculine, but fall in line with the expectations of her gendered experience at work. She is cynical and suspicious of her relatives, especially Valerie, of being the cause of her missing brother Frank's probable death. She is emotionally detached from her relatives as she has no problem pulling a gun on them or interrogating them to seek answers to non-police related questions. Gail is also experiencing marital problems with her husband Eddie, who is abusive to her and repeatedly has affairs with women in town. The most serious indication of the impact of police work stress on Gail's life are her suicide attempts. It is mentioned in the play that she has previously attempted suicide, and she makes two additional attempts during the play—once by firearm and once by pills. This stress from her police work may also have another source - the tension surrounding her gender performance on the job. As RabeHemp states,

Susan Martin's (1980) groundbreaking analysis of female police officers concluded that the conflict between gender roles and occupational role norms resulted in women adopting either the POLICEwoman identity, which stresses overachievement and conformity to the police subculture, or the policeWOMAN identity, which emphasizes conformity to stereotypical feminine roles. ${ }^{30}$

As Gail is constantly shifting between these two roles, POLICEwoman and policeWOMAN, her performance of gender remains in a constant state of flux but veering toward the masculine side of the spectrum. If she performs as a POLICEwoman,

\footnotetext{
${ }^{29}$ Kenneth Dowler and Bruce Arai, "Stress, Gender and Policing: The Impact of Perceived Gender Discrimination on Symptoms of Stress.," International Journal of Police Science \& Management 10, no. 2 (2008): 123.

${ }^{30}$ Rabe-Hemp, "POLICEwomen or PoliceWOMEN?," 114.
} 
her identity as a woman is threatened, but if she performs as a policeWOMAN, her identity as a police offer is threatened. There is no winning for Gail, and she becomes a manifestation of the conflicts surrounding gender identity described in Martin's study.

\section{Character Gender Disruption: Donal}

Donal, the only male character who actually appears in The Butcher of Baraboo, displays highly masculine behaviors and conservative perspectives throughout the course of the play. Donal is only described by Wegrzyn as "male, $50 s$ "31 but the name, Donal, from the Gaelic "Domnhall" meaning "ruler of the world,"32 evokes masculine power and privilege. His identity as Gail and Frank's brother, Valerie's brother-in-law, and Midge's potential biological father is only gradually revealed throughout the play. We also learn that he is married to Sevenly, with whom he has six children. Interestingly, Donal's profession is never named; he is entirely identified according to his domestic relationships (brother, father, husband). As the only man left in the family structure, it would be assumed that Donal would serve as the "patriarch" of the family (including over his sisters and Midge), but his position as patriarch seems to be usurped by the power Valerie and Gail wield, destabilizing his masculine gender performance.

Unbeknownst to him, Sevenly is pregnant with their seventh child. Donal seems to personify the rural conservative American man who drinks whiskey and enjoys his place as head of his immediate household. Fathering six children (and a seventh on the way) with Sevenly, Donal spreads his seed beyond his household as he is the likely father

\footnotetext{
${ }^{31}$ Wegrzyn, The Butcher of Baraboo, n.p.

${ }^{32}$ Mike Campbell, "Meaning, Origin and History of the Name Donald," Behind the Name, accessed April 18, 2019, https://www.behindthename.com/name/donald.
} 
of Midge. Donal appears to function as the "All American Average Joe" early in the play, but as the play progresses the proverbial skeletons come out of his closet and a darker side is revealed. Donal's character may serve as correlative to the town of Baraboo itself; on the surface, it appears to be a charming All-American town in the heartland of America, but in reality, a deeper, darker Baraboo lurks in the shadows.

\section{Character Gender Disruption: Sevenly}

Sevenly is described as "female, 30s" by Wegrzyn. She reveals that her name "was chosen in a resigned sigh. My name was chosen in the way you choose the wood finish of your own casket. There is no number beyond seven." 33 Sevenly's name, and its meaning, provides one of the driving motivations for Sevenly's trying to terminate the seventh child she is carrying. All her female relatives, including her mother, died giving birth to their seventh child, and she wants to live.

In all other aspects of her character, however, Sevenly's performances may be coded as feminine, even hyper-feminine. In the first study of hyperfemininity, psychologists Sarah K. Murnen and Donn Byrne define hyperfemininity as "exaggerated adherence to a stereotypic feminine gender role." 34 Sevenly is a domestic goddess, making Katharine Hepburn's famous brownies, being a stay-at-home mom to six children, and constantly aiming to obey and serve her husband Donal. Psychologists Melissa McKelvie and Stephen R. Gold added to the image of the hyperfeminine woman as "a woman who is alienated from herself and others and who suffers from

\footnotetext{
${ }^{33}$ Wegrzyn, The Butcher of Baraboo, 53.

${ }^{34}$ Murnen and Byrne, "Hyperfemininity: Measurement and Initial Validation of the Construct," 480.
} 
psychological symptoms, such as anxiety and high levels of interpersonal sensitivity." ${ }^{35}$ Sevenly also displays these characteristics; in an anecdote during the dinner party, Sevenly reveals that she would read books to her pet chickens to practice her reading skills. Sevenly developed a bond with one of her pet chickens named Lulu, and she reveals that she "couldn't be the one to...my father took care of Lulu when it was her time to go. ${ }^{\prime 36}$ Throughout the play, Sevenly is overly polite to all of the other characters until she becomes desperate for the abortion pill, highlighting her anxiety and stress related to her pregnancy. By wanting to terminate her pregnancy, Sevenly is destabilizing her hyperfeminine gender role. According to Murnen and Byrne, "hyperfemininity was related to traditional attitudes about the rights and roles of women in society.

Hyperfeminine women reported more negative attitudes about women and more traditional family values." ${ }^{37}$ Sevenly wanting to terminate her pregnancy contradicts the hyperfeminine desire to maintain traditional family values, which destabilizes her hyperfeminine gender performance. Wegrzyn may have made this choice for Sevenly's character to demonstrate the flawed logic of conservative Christian values and the performance of hyperfemininity that it promotes, and uses Sevenly's abortion attempt to call attention to the oppressive nature of these traditional societal values.

\section{Onstage Violence in The Butcher of Baraboo}

In The Butcher of Baraboo, nearly all the violence is committed with a prop or some form of weapon. The weapons of choice (a rolled-up newspaper, a gun, a meat

\footnotetext{
${ }^{35}$ McKelvie and Gold, "Hyperfemininity: Further Definition of the Construct," 225.

${ }^{36}$ Wegrzyn, The Butcher of Baraboo, 20.

${ }^{37}$ Murnen and Byrne, "Hyperfemininity: Measurement and Initial Validation of the Construct," 487.
} 
cleaver, a coffee cup, and a knife) tend to fall within the domestic sphere and may not always be lethal when used, but can certainly cause quite a bit of damage. The acts of violence performed are predominantly used as physical punishment to police the behavior of other members of the family, even if it is as extreme as smashing a coffee cup into someone's head. Research on physical punishment is primarily focused on parent-child discipline dynamics rather than adult-adult discipline, but the intent of physical punishment is essentially the same. Sociologist Murray A. Straus defined physical punishment in his article "Discipline and Deviance: Physical Punishment of Children and Violence and Other Crime in Adulthood" as "a legally permissible physical attack on children. The most common forms are spanking, slapping, grabbing, and shoving a child 'roughly' — with more force than is needed to move the child." ${ }^{38}$ Straus goes on to suggest that physical punishment in children could cause violent behavior in those children when they become adults, which Straus calls "Cultural Spillover Theory." 39 This theory is not inherently gendered in terms of masculine or feminine physical punishments having differing effects on the child. However, pairing the concept of physical punishment with the analyses of these acts of violence point to more substantial analyses of the gender performances of the characters who commit acts of violence within The Butcher of Baraboo.

The first instance of violence within the play is a minor scuffle between Gail and Midge. Gail is attempting to explain where she stages drunk driving accidents to deter

\footnotetext{
${ }^{38}$ Murray A. Straus, "Discipline and Deviance: Physical Punishment of Children and Violence and Other Crime in Adulthood," Social Problems 38, no. 2 (1991): 134.

${ }^{39}$ Ibid., 141.
} 
teenagers from drinking and driving and becomes frustrated at Midge's apparent failure to recognize the road on which Gail stages the accidents:

GAIL: That road-you know where I'm talking right, that busted-up no-traffic road there, you know where I'm talking right?

MIDGE I dunno, Aunt Gail, maybe I'll get it you keep pointing at the wall. (GAIL thwacks MIDGE hard with a bit of rolled-up newspaper) ${ }^{40}$

While this act is not as severe as other acts seen in this study, this moment is indicative of the family dynamics. This family, including its female members, disciplines through physical punishment, which is coded masculine. Gail's weapon of choice in this moment is a rolled-up newspaper, which is reminiscent of a police officer's billy club, which is also evocative of the phallus. This masculine gesture is also amplified by the heightened intensity as Wegrzyn indicates that Gail "thwacks MIDGE hard" rather than delivering a gentler "tap." Gail's behavior is aggressive and authoritative, and Midge has no choice but to acquiesce.

The remainder of the acts of violence in the play occur in the second act of The Butcher of Baraboo. Gail bursts into Valerie's kitchen while high on crystal meth after discovering Eddie, her husband, in bed with another woman. Valerie suggests that while Gail is high, she should not have her gun on her, and Valerie offers to take it from her. Gail refuses to give the gun to Valerie, so Valerie offers Sevenly as an alternative:

SEVENLY: Guns make me feel very uneasy, Valerie.

VALERIE: I don't like guns either and I'm not asking you to use it. Just take it from Gail and set it down over there. You'll give it to Sevenly, won't you?

GAIL: Sure, yeah, sure. I'll give it to Sevenly, I'll give it to her. Come and get it. (SEVENLY approaches. GAIL jabs the gun in SEVENLY's stomach.)

GAIL: I'm just messin.

(GAIL holds the gun in her palm for SEVENLY to take.

SEVENLY takes the gun. VALERIE takes GAIL by the hair and wrenches her head back.)

\footnotetext{
${ }^{40}$ Wegrzyn, The Butcher of Baraboo, 7.
} 
VALERIE: I am sorry for the way Eddie treats you, but you win little sympathy from me when you go all freewheeling with your firearms, pointing your gun like that when she's going to be having a baby.

GAIL: Ohh congratulations a baaaaybe, just what the world needs another baaaay-

(VALERIE gives GAIL's hair a tugging twist.)

GAIL: - hey! [...]

VALERIE: Apologize to your sister-in-law for pointing your gun, and pray to whatever you need to pray to that she learns to tolerate you as much as I've tolerated you all these years.

GAIL: Yeah right.

(VALERIE twists GAIL's hair.)

GAIL: Ow. Sorry.

VALERIE: To her.

GAIL: You got my head wrenched back I can't exactly direct my apologies to anything but the cracked plaster in your dumb ceiling, you called me an idiot, well who's the idiot now-

(VALERIE twists GAIL's hair.)

GAIL: —ow ! Is all I'm sayin is who's the idiot now-

(VALERIE twists.)

GAIL: —ow ! I'm just sayin-

(VALERIE twists.)

GAIL: - OW!

(VALERIE directs GAIL's head towards SEVENLY.)

GAIL: I'm sorry.

VALERIE: Go soak your head in the shower.

(VALERIE releases GAIL.)

GAIL: You're crazy, Valerie. I'm calling the cops.

VALERIE: You are the cops.

GAIL: Well good! I'm glad I know about this! ${ }^{41}$

This is one of the longest and most elaborate sequences of violence seen in any of the plays in the study. Gail pointing her gun at Sevenly's stomach seems to come out of nowhere, which could be a sign that Gail is truly high beyond her control on crystal meth. The fact that she points a gun, a phallus, directly at Sevenly's stomach containing her womb with a fetus inside is a striking gesture of masculine dominance holding femininity, womanhood, and maternity hostage. If Sevenly so much as attempts to

${ }^{41}$ Ibid., 47-48. 
protest, it could prove to be fatal. What remains unclear is why Gail performs this gesture. Is it tied to her mania while on crystal meth? Is this deep-seated trauma Gail has not yet explored? Is it no more than a device to shock the audience into thinking something bad is about to happen? Evidence points to the latter of these questions as Gail steps so easily out of committing this gesture with an "I'm just messin." If there were more severe intentions, they would have been followed through later in the plot. In addition, Gail's "joke" of pointing the gun at Sevenly's stomach is swiftly punished by Valerie, who grabs her by the hair and wrenches her hair back repeatedly until Gail genuinely apologizes to Sevenly for what she has done. Gail did not think about any repercussions for her poor "joke," and when she attempts to joke her way out of it with Valerie, she continues to have her hair pulled. In the end, Valerie is the one who asserts the most dominance by punishing Gail for threatening Sevenly and stepping out of line with sane, reasonable behavior. Valerie and Gail both perform aggressive and violent masculine acts in this moment, while Sevenly remains passive.

But even Sevenly transgresses from a feminine to masculine performance of violence on one occasion. Midge returns home in possession of RU-486, which will enable Sevenly to have a medical abortion. When Valerie attempts to intervene and take the medication away, Sevenly aims the gun at them, holding Midge and Valerie hostage until she can leave with the medication:

SEVENLY: [...] This will be my seventh child. I have to do something. Now. Give me the bag.

(VALERIE doesn't release the bag. SEVENLY puts the gun to MIDGE's head.) MIDGE: Mom?

(VALERIE gives up the bag to SEVENLY. SEVENLY puts down the gun, takes her brownie pan, and exits.)

VALERIE: Go check on your Aunt Gail. (MIDGE exits. VALERIE goes to the phone, dials.) 
VALERIE: Donal? Hi, it's Valerie. You're sure right to be worried about your wife. $^{42}$

Sevenly is desperate to stay alive and to avoid what she believes to be a curse placed upon the women in her family. Valerie is faced with a choice of her daughter's life ending or the death of Sevenly's fetus. As Midge is her only child, Valerie performs a feminine act by handing over the medication Sevenly wants in exchange for keeping Midge alive. When Sevenly gets what she wants, she puts down the gun in exchange for her brownie pan. Sevenly's destabilized gender performance (from gun to brownie pan) is further complicated by the fact that she is also carrying the medication to kill her unborn child. These juxtapositions send the message that Sevenly is capable of masculine aggression yet tied to domesticity, and perhaps most significantly, her maternal instinct does not outweigh her desire to live. She violates the long-held belief that mothers will willingly sacrifice their own lives for that of their children. In this moment, one mother tries to save a child's life and the other tries to end one. Valerie displays her "natural" maternal instinct, which is then subverted by Sevenly's threats to end the lives of two children. Severing Sevenly's motherly performance undermines her feminine and domestic performances, making her gender performance less stable.

Donal, the only masculine character of the show, only performs one act of violence during the play. Donal confronts Midge about providing Sevenly with the abortion medication, which he has flushed down the toilet before Sevenly could take it. Midge makes a cryptic remark about people disappearing from the town when they feel lonely or sad, which raises Donal's suspicions regarding his missing brother Frank.

${ }^{42}$ Ibid., 53. 
DONAL: Don't—Midge-I'm through playing games, you understand me now? What happened to Frank. (He grabs her arm, hard.) Did you do something to him?

MIDGE: (Shakes him off) Don't touch me! Don't.

DONAL: Please, just, Midge. ${ }^{43}$

In this moment, Donal is asserting his masculinity through brute strength, using his strength as a tactic to force Midge to confess to what she knows about Frank's disappearance. Midge thwarts this act of masculinity by shaking him off and verbally asserting herself, which forces Donal to change his tactics and plead with her. This shift goes from highly masculine to a slightly more feminine performance as his use of force was not enough to gain dominance over Midge. Again, violence is used here as a form of familial physical punishment; Donal is disciplining his niece Midge for withholding information from him, and once the violent act is completed, Midge informs Donal that he, rather than his brother Frank may in fact be her real father.

The morning after the confrontation between Donal and Midge, Valerie asks Midge about a suspicious "ding" that she has discovered in her meat cleaver. Midge confesses that she borrowed the meat cleaver for protection as she was in the woods the night before. Valerie plays it cool by brushing it off as no big deal, but it is a trick she is playing on Midge:

VALERIE: Accidents happen. Just, in the future, please ask me if you'd like to borrow my cutlery, all right?

MIDGE: All right.

(VALERIE hits MIDGE with a stunning blow upside the head with a coffee mug.) MIDGE: AAAAAOOOW!!! OW! FUCK!

VALERIE: That always works in the movies, I don't understand. (She grabs MIDGE by the neck and wrangles her in a sleeper choke hold to compress the carotid artery and black her out.) Did you see in the paper this morning, City Council voted to abolish the beer tent at the Old Fashioned Days Festival. Didn't I

${ }^{43}$ Ibid., 64. 
say that was going to happen sooner or later, because it's a family event? You said it wasn't going to happen, but from my mouth to God's ear.

(MIDGE goes limp.)

VALERIE: ...I'm sorry, sweetheart, just a bit of necessary prep work.

MIDGE: (Wakes) What the fu-?

(VALERIE slams MIDGE's head on the table, and pushes her on top of the table. MIDGE is finally unconscious. VALERIE ties MIDGE's feet with her robe tie.

SEVENLY enters with her brownie pan.)

SEVENLY: Valerie, have you heard from D...?

VALERIE: Oh! She's fine. Midge has these spells. Are those more brownies for us?

SEVENLY: I had leftovers.

VALERIE: That's really nice, I've never had a next-door neighbor as nice as you before.

SEVENLY: Why are you doing that?

VALERIE: She'll be wily and I don't want her hurting herself. Really, it's for her own safety and comfort.

(SEVENLY helps VALERIE lift MIDGE on the table and will hog-tie her.) SEVENLY: Have you heard from Donal yet? ${ }^{44}$

Again, Wegrzyn has constructed a highly complex series of violent events that are tied to disciplining the behavior of women in the play. Valerie decides to punish Midge for "borrowing" her meat cleaver, but the severity of this sequence indicates that Valerie is punishing Midge for much more than just this transgression. Valerie seems to be punishing Midge for withholding information about the disappearance of Frank and Donal, and Valerie suspects that Midge may have killed them both. Even though Valerie is punishing Midge, she is attempting to make it as painless as possible by attempting to knock her unconscious with a coffee mug. When that attempt fails, Valerie puts Midge in a sleeper hold, which works momentarily, but then fails as Midge wakes up for a second time. The third attempt to force Midge into unconsciousness is the most violent as Valerie slams Midge's head into the butcher block, and this attempt is successful. In this sequence of violence, Valerie is treating Midge like one of the animals she is about to

${ }^{44}$ Ibid., 68-69. 
butcher; Valerie does whatever she needs to do to force her prey to lose consciousness so it does not fight against her when she attempts to tie it up and then kill it. This performance of her career in the domestic space of her own kitchen on her own daughter creates a highly masculine performance as she is "manhandling” Midge's unconscious body into submission. In addition, Valerie hogties Midge with Valerie's bathrobe tie, which conveys not only an image of meat on display, but a sexual display of womanhood on display at complete vulnerability. Sevenly ends up aiding in this process, which makes her gender performance, along with Valerie's, swing masculine.

Valerie exits the room to grab a copy of the book Goodnight, Moon to read her child one last bedtime story before executing her. Immediately before attempting to murder her own daughter, Valerie makes one final motherly gesture - attempting to comfort and soothe her frightened child. This is a major disruption of Valerie's feminine gender performance. While Valerie is gone, Midge regains consciousness and begs Sevenly to untie her. Valerie returns as Sevenly attempts to untie the complex knots. Valerie informs Sevenly that Midge is the last person to see Donal alive and that Midge knows more than she has disclosed to either of them. When Midge confesses that she left Donal at the lake unharmed, Valerie and Sevenly do not believe her, which provokes Valerie to more disciplinary action:

VALERIE: Well sorry you're gonna look odd if I tear one of your ear flaps off the side of your head.

(VALERIE twists one of MIDGE's ears.)

MIDGE: Gaaaahhhhhh!!! Stop!!!

(VALERIE stops) $^{45}$

${ }^{45}$ Ibid., 72. 
Twisting ears is a common trope seen in film and television by parents who are attempting to discipline their children, and this moment is a recreation of this somewhat comic form of parental physical punishment. Valerie is using this ear twist as a reminder that she is the one in power, so it would behoove Midge to comply with Valerie's demands. This gesture maintains Valerie's masculine gender performance, which continues throughout the last moment of violence between Valerie and Midge. Valerie has given Goodnight, Moon to Sevenly who begins to read the book aloud. As Sevenly reads, Valerie reminds Midge of the times when she would come to the shop to watch Valerie behead chickens and ask where chickens go after they die. Valerie reminds Midge that they went to heaven and suggests that Midge focus on that thought for comfort in the last few moments of her life. To convince Midge to tell her the truth, Valerie commands:

VALERIE: (She holds MIDGE's head down, cleaver at the ready.) You tell me the truth now or this blade is going through your neck. MIDGE: Was your fault he left, Mom! Was always your fault! (VALERIE raises the cleaver to chop MIDGE's neck, and MIDGE cries in terror. The kitchen door flies open and DONAL roars into the kitchen. VALERIE halts, stunned. DONAL is bundled up in scarf, hat, hood, obscured under layers, nearly frozen. $)^{46}$

This moment serves as the climax of the play. Valerie is performing at her most masculine, holding down her daughter's head to prevent her from moving while she beheads her. Midge blames Valerie for Frank's desertion, which is not the "truth" that Valerie is seeking, so she raises her arm to behead Midge just as Donal bursts through the door and halts the action. Valerie has sacrificed all aspects of her femininity in this moment; she is about to butcher her one and only child, equating her daughter to no more

${ }^{46}$ Ibid., 73. 
than an animal deserving of slaughter. Her violent, cold, and calculating manner take over, and as a result, she kills her femininity, motherhood, and womanhood in the process.

The final instance of violence in The Butcher of Baraboo occurs between Gail and Valerie. Sevenly and Donal have left Valerie's kitchen to tend to Donal's hypothermia, and Gail enters freshly discharged from the hospital after overdosing on pain pills. Seemingly nonplussed by the shenanigans she has walked into, Gail unties Midge as though finding her niece hogtied on a butcher block is completely commonplace for this family. In a final desperate act to discover what happened to Frank, Gail stabs Valerie:

GAIL: [...] Oh, Valerie, thanks for driving me to the hospital yesterday, I really appreciate that. I'd like to return the favor, so feel free to give me a call if you need a ride home from the hospital today.

VALERIE: A ride home from the hospital today?

GAIL: For the stitches.

VALERIE: For the stitches?

GAIL: For when I stick you with my pocket knife.

VALERIE: For when you what?

(GAIL sticks her pocket knife in VALERIE's side.)

GAIL: Not so piss-ant now, eh?

VALERIE: You stabbed me! ${ }^{47}$

This act of violence is also used as physical punishment by Gail. She knows that she has not delivered a fatal wound, but she does not confess that to Valerie until she gets the information she needs from Valerie. Gail offers forgiveness to Valerie for whatever Valerie has done to Frank in the form of a handshake, and Valerie accepts the handshake. Gail interprets this acceptance of the handshake as admittance of guilt for killing Frank. Gail asserts her authority and her strength using a knife, a phallus, to generate a false confession out of Valerie, making Gail's gender performance highly masculine. This

${ }^{47}$ Ibid., 75. 
moment could also serve as punishment for Valerie for her masculine gender performance, and that transgression of gender causes her immense pain.

\section{Conclusion}

Wegrzyn's The Butcher of Baraboo brings together female characters who, through their disrupted gender performances, challenge essentialist ideas about gender construction that empowers men and marginalizes women. The women characters in The Butcher of Baraboo both uphold and challenge the conservative values of their small community in rural Wisconsin, creating complex, unstable constructions of gender, femininity, and womanhood. Wegrzyn has set the play in a kitchen, a domestic interior, which is a gendered space that is mostly occupied by women. These women are identified by familial relationships (mother, daughter, sister-in-law, etc.) and dominate the action and stage time; this space is a woman's world, and it is the only space in which they have control. The "outside world," is dominated by the values of the conservative Midwest town and ruled by husbands, fathers, and bosses.

But this is no ordinary kitchen; pies and cookies are not made in this space. Rather, this kitchen functions as a butcher shop. It is home to violence and death, with a gallon of blood in the refrigerator. These women live in the abject from Baraboo, and this is the place where they have been sent for slaughter. Philosophy professor Noelle McAfee suggests, in her explication of Kristeva's theory of the subject-in-process, "that we are all discrete beings learning to act independently and autonomously...Kristeva offers us... a self that is always in process and hetereogeneous [sic]. The self's affective 
energies continue to destabilize any given self-understanding." ${ }^{48}$ In Kristevan terms, these characters are subjects-in-process, and they are trying on different identities to see if they can find one that "fits" with the world of Baraboo, a process that strengthens this play's anti-essentialist critique of identity.

Valerie, the protagonist and namesake of The Butcher of Baraboo, is a dutiful, hard-working mother attempting to keep what little of her family she has left together. By working in butchery, she exudes masculine characteristics that causes others to doubt her innocence in her husband's disappearance, deepening her abjection from her town and her relatives. By butchering animals (and nearly butchering her own daughter), she manifests heightened levels of abjection as she directly works with the boundary of life and death, separating blood and offal from valuable flesh. The comic double entendre of Valerie's profession — butcher of meat and potential butcher of people — adds absurdity to her characterization as she finds a way to inhabit both sides of the double entendre by the end of the play. Valerie is a butcher who is suspected of murder who has a bastard child as the result of an extramarital affair; she later tortures and nearly kills her child and is then identified as the responsible party for her husband's death. After this discovery, she brags about the fact that she will get away with murder completely unscathed. This abject space is the only place where these women can live until their executioner (whether that is God or a fellow family member) determines that their existence is no longer valid or necessary.

${ }^{48}$ Noelle McAfee, Julia Kristeva, Routledge Critical Thinkers (New York: Routledge, 2004), 41. 
Midge's role as an attempted abortionist underscores her abject condition. Midge continues to live in abjection from the town of Baraboo by illegally obtaining abortion pills for Sevenly, contradicting the conservative values of Baraboo. Midge's abjection is furthered by her identity as a closeted lesbian and her discovery that she is an illegitimate child, or a "bastard," which codes masculine and outside the bounds of normative family structure. Midge's profession may also be expressed in terms of double entendre; she is a drug dealer, both legally and illegally. This absurdist choice adds to the duality that Midge inhabits during the play. Midge is a pharmacist and a criminal - a drug dealer to children - 'bad daughter' 'bad role model' an enabler to Sevenly's attempts to abort a child.

Gail's conflicting gender roles include wife/homemaker and police officer, caregiver and violent assaulter (she stabs Valerie). She repeatedly crumbles under the pressures at work and her abusive marriage, going so far as to attempt suicide. Gail's absurdist professional double entendre as a policeWOMAN and a POLICEwoman exemplifies the difficulties she faces as she attempts to find a stable gender identity through her profession, and ultimately never succeeds.

Sevenly and Donal serve the play as representatives of the "All American" values of the town of Baraboo-Donal asserts his masculine dominance over Sevenly, bribing Midge to stay away from her and preventing Sevenly from aborting his seventh child, and Sevenly presents the hyperfeminine ideal that "good" housewives should aspire to be. Both Sevenly and Donal disrupt these images, however, through their use of violence or threats of violence, showing that there is a darker side to their idyllic American lifestyle. Sevenly destabilizes her hyperfeminine performance of making Katharine Hepburn's 
brownies by willfully attempting to get an abortion (breaking the laws of God and the wishes of her husband to do so). When Donal returns from the frozen lake, frostbitten and downtrodden, the couple reverses their gender roles - Sevenly becomes the "man" of the household, dictating to a submissive Donal what needs to happen to keep him alive. When this reversal occurs, Sevenly focuses on her needs and her needs only; she ignores the pleas from Valerie that she stay in the kitchen.

Their shockingly violent acts appear commonplace in Wegrzyn's uncanny domestic dystopia. With this play, Wegrzyn could be presenting the butcher shop as a metaphor for a brutal, hierarchal, and exclusive American society. American society determines who is abject and who is not; those who are selected as prize cuts are upheld, and those who are determined to be offal are tossed away and left to rot. In this process, women are most vulnerable to exclusion. Through Wegrzyn's use of dark (often grotesque) humor, she satirizes the gendered expectations of women living in these conservative misogynist conditions. 


\section{CHAPTER SIX}

\section{Conclusion: "That's some subversive shit right there."}

The purpose of this dissertation was to advance inquiry into plays by American women playwrights containing onstage acts of violence by aggressive women. By examining these plays with particular attention to the relationship between gender and these violent acts, I hoped to shed light on the function and purpose of the acts of violence and how they relate to existing notions of femininity, gender, and womanhood. It was also an aim of this study to explore how other dramaturgical choices (of plot, setting, context, and characterization) contributed to the meaning of these plays vis a vis representations of gender. I also hope that this investigation will increase interest in the works of these two contemporary feminist playwrights who, with their own genderdefying use of dark comedy and satire to serve feminist agendas, are challenging dramaturgical as well as social and cultural traditions.

Each of these works, Roadkill Confidential and That Pretty Pretty; Or, The Rape Play by Sheila Callaghan and Killing Women and The Butcher of Baraboo by Marisa Wegrzyn, offer striking challenges to heteronormative gender identities. Women perform masculine gestures and actions (including myriad acts of armed and unarmed violence), work in traditionally masculine careers, and take power away from men within the world of the play. At the same time, the men within these plays take one of two routes; either they perform heteronormative masculinity to the point that it becomes an overdone hypermasculine performance that doubles back on itself in the form of parody, or the men perform feminine acts and behaviors that "queer" their gender identities. Both modes 
underscore the notion of gender as performance. Although all the plays call attention to and support Judith Butler's anti-essentialist theories regarding how gender is constructed through repeated performances, Sheila Callaghan's metatheatrical That Pretty Pretty is an especially vivid manifestation of the process.

\section{Summary of Findings}

In Roadkill Confidential, Callaghan challenged gender norms and expectations through portrayals of a range of conflicting masculine and feminine behaviors. FBI Man's hypermasculine identity is deconstructed over the course of the play, along with his male gaze, as the female protagonist Trevor turns the tables on him and reclaims power over her own story. Trevor's methodology of violence, vehicular violence, is almost never performed by women in the real world, so to have a woman character repeat sequences of vehicular violence onstage represents a notable transgression of gender norms and expectations.

In That Pretty Pretty; Or, The Rape Play, Callaghan slaps the audience across the face with a barrage of absurdist, misogynistic imagery, forcing the audience to confront and question their revulsion/fascination with such images. Through Owen's (eventually deconstructed) male gaze, the play reflects back to the audience the specifically gendered, misogynistic, and sexist media it loves to consume and questions the legitimacy of that consumption. Using absurdist theatre techniques, Callaghan's characters perform gender parody to demonstrate the absurdity of gender norms that are trafficked by American society, including some of the "queerest" performances of gender and sexuality depicted in these plays. In Callaghan's conclusion, an unheard question from the audience, "blows [Owen's] mind," rendering him utterly mute. Here Callaghan posits that the only way to 
overcome a misogynistic gender system is by dismantling the male gaze and male discourse, perhaps letting women speak about their own experiences.

In Killing Women, Wegrzyn examines, again through a satirical and absurdist lens, the struggles women face in the workforce by presenting this struggle within a male-dominated, criminal organization. This play functions as a satirical dramatization of Joan Acker's theory of gendered organizations, positing that the gendered hierarchy of all-American workplaces, are criminal in their flagrant misogyny, sexism, and heteronormative structures that prevent women from succeeding. Even when the women are the best and most successful at their job (which in this case happens to be murder), institutional sexism (the proverbial glass ceiling) prevents them from equal opportunity.

In The Butcher of Baraboo, Wegrzyn creates women characters who disrupt essentialist notions of gender, womanhood, motherhood, and femininity. Their performances of masculine careers, grotesque violent behavior, physical punishment, and two women's attempted murder of their own children, disrupt expectations of what mothers and women should do and should be. None of the women characters "fit" in their conservative world, which suggests that Wegrzyn could be arguing that these representations of women do not fit in American society, as currently structured, either. By presenting this, Wegrzyn questions the boundaries that are placed around the women and why they live in abjection for behaviors that would be normalized or expected of the men in the same circumstances. Their abjection from Baraboo and their entrapment in the kitchen of Valerie's home could function as a parallel of how American society treats women. They are abject and banned from participating in the society, so they try on 
identities like Kristeva's concept of the "subject-in-progress" and no matter what identity they try (even the masculine ones), they are unable to "fit in."

One major common thread between all four of these works is that they all bend genres, as well as genders, presenting brutal acts of violence, including sexual violence, with humor, in tones that I have described as satirical, absurd, grotesque, or darkly comic. In these dramaturgical choices, both playwrights, to some degree, violate a longstanding gendered assumption that women are incapable of humor. As English professor Lisa Colletta notes,

scholars and critics - from Congreve to Christopher Hitchens - have repeatedly claimed that women are incapable of having a sense of humor. They are essentially and materially unequipped for it, too associated with nature and their own bodies to perceive the contradictions and juxtapositions that are at the heart of comedy. ${ }^{1}$

Clearly, Congreve and Hitchens are unfamiliar with the works of Callaghan and

Wegrzyn, whose ability to craft comic contradictions and ironic juxtapositions seems remarkable. The comedy these playwrights present is predominantly satirical in nature, and very dark, which, as Colletta acknowledges, has predominantly been associated with the masculine:

Satire is a form of attack that has generally been attributed to male aggressiveness. So, if it has been controversial to claim that women even have a sense of humor, it has been even harder to make a claim for female participation in the tradition of dark humor and satire- a tradition that is long, rich, varied, funny, and most definitely aggressive. ${ }^{2}$

Colletta argues, however, for emerging challenges to that tradition, a movement of which Callaghan and Wegrzyn seem exemplary: "in our current historical moment, this tradition

${ }^{1}$ Colletta, "Postmodernity and the Use of Political Satire," 207.

${ }^{2}$ Ibid., 209. 
has taken on new and more destabilizing forms, if not necessarily more 'feminist.' ${ }^{3}$ By using dark comedy to satirize American culture, especially gendered violence and misogyny, Callaghan and Wegrzyn are themselves disrupting gender performance and essentialist notions about women writers and comedy. Not only are Callaghan and Wegrzyn disrupting their own gender performances, they are attempting to disrupt longheld beliefs about American society and cultural norms. Colletta argues that this is the way that satirists can create change-by sending a call to action with their work:

Transforming anger and frustration into action is satire's corrective aim. Its efficacy relies on the ability of the audience to recognize the irony that is at the heart of its humor. Injustice, vice, stupidity, or cruelty have to be recognized as the object of the attack, and they need to be judged against a better moral standard. The satirist may use irony with vicious anger, but the irony always has a deeper meaning and a social signification beyond that of the humor. ${ }^{4}$

Cruelty and injustice are the primary targets of the attacks by Callaghan and Wegrzyn. They want their audiences to see the cruel, unjust working and living conditions that women experience, the oppressive circumstances that the misogynist culture has set up against all women, and then hope to move the audience to act against their oppressors.

If the theorists are correct in asserting that this use of humor and satire constitutes a call to action, this dramaturgical choice may open the possibility of perceiving empowerment in these representations of violent women and perceiving within these acts of violence a metaphor of extreme resistance to unbearable existing conditions. By creating women who disrupt the expectations of their gender, Callaghan and Wegrzyn lift subconscious barriers that only those in power can create change; anyone can create

\footnotetext{
${ }^{3}$ Ibid.

${ }^{4}$ Ibid., 212.
} 
change if they believe that they can do so, and these representations aid in that empowerment process.

One shortcoming of the radical disruptions of gender that Callaghan and Wegrzyn have created is both Callaghan and Wegrzyn identify all the characters in the dramatis personae of these plays in terms of the sex binary of male and female. In addition, all the characters identified as "female" use she/her/hers pronouns. If these were changed to man and woman, or even no gender identities listed at all, there may be more possibilities for radical disruptions of gender within the world of the play.

\section{Staging Violence: Realism, Romanticism, and Reinforcing Gender Disruptions}

Designing these violent moments in production would be a daunting task for most violence designers. There are several factors that one must consider in production. How realistic will the violence be? What technical abilities does the performance space have? How can the choices that the violence designer, director, and actor make in staging these acts help or hinder the gender disruption suggested in the text? In the following section, I will discuss selected, representative moments in each of the plays in terms of designing violence to assist in the gender subversions of the moments of violence and the difficulties of staging some of these violent moments onstage.

\section{Designing Violence in Roadkill Confidential}

I am fortunate enough to have personal experience in the difficulties of staging some of the violence in Roadkill Confidential in an advanced directing class. In this class, we were given the added complication of using a specific contemporary theatre style while directing our piece. For this project, I chose to use Brechtian techniques, as many 
of the qualities of the play seem to fall in line with the style-alienation, use of projection of scene titles; characters directly address the audience; and the staging of the play in an art installation-esque space would work in tandem with the requirements of the show. In addition, my limited budget would allow for me to play with extreme minimalism of the piece in terms of prop usage and light sources. Finally, Brecht's "epic theatre" techniques are generally considered effective means by which to stage theatre intended to raise social awareness or effect social change.

For this project I staged two of the violent moments within the play- the initial accident scene and the first Hit Animal Dance. The actor playing Trevor sat on a black acting cube, pantomiming her driving down the road with her hands around an imaginary steering wheel and feet on imaginary pedals. The other members of the ensemble made the sounds of her driving down the road ("errs" and "vrooms" accordingly) standing near her but obviously not in the car with her. Another actor placed a rabbit hand puppet on her hand and manipulated the rabbit as if it was walking across the road ahead. When the collision with the rabbit occurred, the two actors making the car noises were directed to make screeching tire sounds and one to stomp her foot on the floor to indicate impact of the rabbit with the vehicle. The puppeteer would then raise the rabbit high in the air as if it was struck and would scream, followed by a resounding thud of the rabbit on the stage floor, now flipped on its back, displaying a red streak of blood across its stomach. Trevor then pantomimed getting out of the car, slid the injured rabbit puppet off of the hand of the puppeteer, and placed it behind her on the acting block to indicate she has placed the animal in the car. This process, depending on the moment, would repeat with the ensemble shifting who was making the vehicle sounds and who was puppeteering a rabbit 
hand puppet. One of my actors was particularly talented in puppeteering, so her rabbit would often still be alive after being struck, causing Trevor to flinch and back away from the rabbit before approaching it with more caution in response to the flinching.

While this staging was useful for exploring Brechtian technique, I do not think it highlighted or reinforced the disruption of gender within these moments of the play. As the entire ensemble was comprised of women, the gender roles and expectations faded to the background as women were playing characters named FBI Man and Frizzy Haired Man, which de-emphasized the impact of gender disruption on these moments. In addition, the Brechtian technique of demonstrating that the rabbits were puppets (the puppeteers were always in clear view of the audience), gave the audience permission to accept the fact that the violence they were seeing wasn't "real" and had no real consequences.

Should I attempt to stage this moment of violence again to reinforce its subversive potential regarding gender identity, there are several choices that I would make differently to create a more faithful, realistic context; rather than having actors follow the sounds of the vehicle, I would use recorded sound to create the atmosphere, sound of driving, and eventual collisions. I would also use a vehicle frame with the front of the car intact so the audience could see the headlights and have a sense of what kind of car that Trevor is using as a weapon. The performance space would need some sort of masking towards the front of the vehicle that would not be obvious to the audience to cover a device to launch animal skins (or very realistic-looking stuffed animals) at the grill of the car to indicate the moment of impact with each animal. If possible, I would also like to incorporate some sort of hydraulics in the front of the vehicle itself to indicate when the 
vehicle has specifically run the animal over (a "bump" that the vehicle has gone over). Roadkill is often something that catches drivers off-guard; they are not anticipating colliding with a deer on the way to their destination. Having an animal launched directly at the front of the vehicle without prior knowledge from the audience would create a visceral reaction in both the actor and the audience. Using realism as opposed to Brechtian techniques may provide a stronger subversion of gender that would support the text better as the audience is perceiving these gender subversions as "real" rather than as another aspect of the "distancing effect" Brecht was so fond of. Because audiences are not used to seeing women enact violence on stage, seeing them do so is already surprising in and of itself. This challenges the efficacy of Brechtian techniques for political theatre as this act is already a challenge to stereotypes surrounding women and violence. By eliciting a more visceral reaction from the audience (such as fear, horror, and repulsion), Trevor's gender performance is disrupted more effectively than using further alienation to force the audience to think about what they are seeing. It is already alienating to see women commit realistic acts of violence; it does not need additional layers to alienate further.

\section{Designing Violence in That Pretty Pretty; Or, the Rape Play}

I have not been able to work on a production of That Pretty Pretty as a violence and intimacy designer, but using my knowledge as both, I will be examining parallel violence in the first two scenes (Valerie shooting Rodney after Agnes seduces him, and Owen shooting Agnes after Rodney seduces her) to discuss how the violence presented in these two moments might be staged in order to support the gender subversion of these moments. 
The first moment of violence in the entire play catches the audience by surprise:

RODNEY

Do not leave the fucking room.

A beat. VALERIE reaches into her purse and pulls out a gun. RODNEY (cont.)

Wait.

\section{VALERIE shoots RODNEY in the head. Blood hits the wall and the floor. AGNES}

GROSS. Gross gross gross get him off me...

VALERIE helps get RODNEY off AGNES. They roll him onto the floor. ${ }^{5}$

Theatrical firearms are one of the most difficult tools to use effectively in a theatre. They are notoriously finicky, require significant amounts of maintenance, and are still very dangerous, even with the use of blank rounds. As this moment is an attempt to catch the audience off-guard, my preference as a violence designer would be to use a live-firing blank round in an easily concealable pistol for this moment. Blood packs and an "electrical squib" would also be needed to be attached to Rodney's back and to explode outward on the set wall behind him to create the "blood spatter" effect that is so often used in movies. As there would be a reliance on the effectiveness of all these devices, they would need to be maintained and checked daily to ensure they are working properly, but they are bound to malfunction at some point. Should the electrical squib and blood pack not detonate, Agnes would need to be in close enough proximity to detonate them herself (or, at the very least, pop the blood bag open so the blood spillage and seepage could occur on the bed and on Agnes). I would want to portray this moment of violence as realistically as possible to support the gender subversion of the characters and to support the "surprise" of Valerie drawing out her gun and shooting Rodney. While the shooting needs to be realistic, the amount of blood in the packet could be highly

\footnotetext{
${ }^{5}$ Callaghan, "That Pretty Pretty; Or, the Rape Play," 239.
} 
excessive to aid in Callaghan's description of something being "off" about these sequences of violence. Rather than undermine the severity of the action, I would choose to exaggerate the reaction to heighten the subversion of Valerie's gender performance in this moment. The more realistic this moment of violence is for the audience, the more absurd the subsequent, corresponding moment of violence will seem:

\section{AGNES}

Do not leave the fucking room.

A beat. OWEN reaches into his coat and pulls out a gun. AGNES (cont.)

Wait.

OWEN shoots AGNES in the face. Them he pulls out a machete from his coat and hacks her. OWEN

Shing! Taste the blade! Skeeee-rumptious!

Then he pulls a sledgehammer from the closet and begins slamming it into her. Blood hits the wall. OWEN (cont.)

Rahg! World smells a whole lot better without your reeking hole... He is finally done. ${ }^{6}$

For this moment, I would want to replicate the blank-firing round with squib and blood pack strategy from the first version of this scene, but lean into the absurdity with the addition of the machete and sledgehammer. If blood packets were also stored on both sides of Agnes' body, Owen could target those areas with a dulled theatrical prop machete while also having a blood pump stream system in his shirt sleeve to maneuver and point in the direction of the machete blade to give the sense that the machete blade is flinging blood around the room. By the time the sledgehammer comes into play, there should be ample amounts of blood surrounding Agnes, so that if Owen strikes one of those pools of blood, the effect will be a huge spray and splash of blood that would evoke the tone of a bad slasher film. The reason I would want to lean into the absurdity of these

\footnotetext{
${ }^{6}$ Ibid., 257.
} 
added tools of violence for this moment would be to demonstrate the absurd lengths that Owen is willing to go to satiate his anger; in other words, I would want to turn Owen's own hypermasculine performance against him and undermine his hypermasculine performance by highlighting the stupidity of inflicting massive amounts of pain and trauma on a dead body. These choices also underscore the macabre, comic tones of the play and further the disruption of the gender performance because the more extreme Owen's violence is, the more hypermasculine he seems, and the more hypermasculine he seems, the more likely that hypermasculinity will double back on itself and read as absurdity.

As both moments also graphically depict sexual assault and necrophilia, consentbased practices would be essential to crafting the stage picture of these moments. The actors would have equal say in the creation of the stage pictures of these moments to ensure actor safety and comfort. By translating these moments into the language of choreography (for example, using counts or describing the level of intensity and shape of the physical contact), I will be creating a space for the actors (as opposed to the audience) to have emotional distance from the "reality" of the acts they are depicting and to focus on the elements of my violence and intimacy design to tell the story to the audience. Finally, I would encourage the actors to engage in a de-roling process after each rehearsal to "close the book" on rehearsal for the evening, create a space of conversation where any issues can be raised or addressed, and to remind the actors that they are acting these acts of violence, not actually experiencing them. Designing Violence in Killing Women 
For the purposes of discussing how staging violent moments may impact their subversive messages, I will consider how I would design the only two moments of completed violence within the play, both committed by women: the murder of Baxter by Gwen in the prologue, and the murder of Joe Lunchbox via lethal injection by Lucy.

Like the other instances of gun violence discussed earlier, I would want Gwen to use a blank-firing firearm to kill Baxter. As this act of murder is a surprise to the audience (I would doubt many audience members would expect a killing so early in the play), I would want a small concealable pistol that Gwen could easily hide in the pocket of her robe. To add to the surprise of the moment, I would suggest that during the prologue, the actors are as still as possible once they enter the scene. By creating this physical tension between the characters, the audience is "tipped off" that something is amiss in the dynamic between the three characters, so when Gwen pulls the gun out of her robe and sharply holds it up to shoot Baxter, the audience barely has enough time to respond to the gesture before the gun goes off. In addition, there should be some uncomfortable distance between Gwen and the pair of Baxter and Abby to indicate that the group is at odds with Gwen even though Gwen and Baxter are married. One of the elements that is essential to staging this moment convincingly is that Gwen points the gun slightly upstage of Baxter so that any debris that may fly out of the gun from the blank round would miss him and not damage his costume.

One of the reasons that it is important to stage this moment as realistically as possible is to give the audience reason to suspect that all the subsequent gun violence in the play has a realistic chance of being completed or performed. If the first act of violence is performed ineffectively, the remaining acts of violence will not have the same 
intended effect on the audience. By enforcing from the beginning of the show that these guns can function and can be lethal to the characters, each instance of threatened gun violence thereafter will seem like a credible threat to the audience. This is important in reinforcing the gender performances of the women wielding the guns as these gestures are masculine but being performed by women, and the last thing I would want to do as a violence designer is take away any potential power that could be given to the female characters later in the play. When it seems realistic for a woman to be committing the acts of violence, the more realistic the fear, horror, and power becomes for the audience.

In terms of characterization, Gwen should evoke a sense of concern and bewilderment for the audience but without falling into the hysterical, nagging housewife trap. Should the actor perform Gwen as hysterical, the surprise of the gun would be undermined, the "masculinity" of the performance would be undermined, and it would seem incongruous to the cold, calculating Gwen we see hold Abby at gunpoint later in the play.

The same line of logic holds true for the second act of violence in the play. To stage the moment of lethal injection between Lucy and Joe, the audience needs to see Lucy realistically push the plunger down on Joe's vein. Luckily, many stunt and weapons organizations have developed trick hypodermic needles for this very purpose. When the needle is pressed against the skin, the needle will retract into the syringe in a specialized compartment that the plunger of the needle surrounds. This way, the audience sees the effect of a needle penetrating the skin, and Lucy would still push down on the plunger of the syringe to indicate "injection" into Joe Lunchbox. Joe would then have to realistically act as though he was collapsing until the lights faded indicating the end of the scene. By 
portraying this second form of violence realistically so early in the play, the audience buys into the reality of the world that violence can manifest in many forms and can be lethal to those who become victims of the violence.

To reinforce the gender subversion of Lucy, I would recommend leaning into the "romantic" atmosphere of the scene. As Joe and Lucy dance, the music they are dancing to could swell, the lights could shift to red or dim, and the actors themselves could have their bodies pressed against one another as they sway to the music. This romantic imagery would then be disrupted by the death of Joe, who could slowly collapse to the ground, indicating his death. The more feminine Lucy appears, and the more heteronormative a "date" they seem to be having, the more Lucy's act disrupts and challenges the assumptions around gender and women's methods of violence.

\section{Designing Violence in The Butcher of Baraboo}

A violence designer's worst nightmare is dealing with sharp objects in a production. The risk of injury is heightened to a tremendous degree. The greatest challenge, then, is how to convincingly stage the sharpness of the meat cleaver for the audience, which repeatedly gets thrown into the butcher block and cleaves a Starbucks coffee bag in twain before it is almost used on an actor. One solution is to have designated "holding" knicks in the butcher block that have been constructed specifically for holding the meat cleaver when it makes contact with the knick in the butcher block. This way, the cleaver can be dull and puts no actors at risk for accidentally cutting themselves on the cleaver. The same idea could work for the Starbucks coffee bag by having pre-sliced the bag in half and holding the seams together with scotch tape within the bag, so when the effort from the cut is made, it appears to "slice" the bag in half, 
making the audience buy into the fact that the meat cleaver is indeed sharp for the final beheading moment. An option that may appeal to many violence designers and fight choreographers, which is highly dangerous if implemented, is to have two identical meat cleavers - one sharp and one dull. The sharp meat cleaver would be used throughout the production and would then be swapped with the dull meat cleaver for the final scene in the play. This would not be a course of action I would choose, however, as there is risk that the actors could still injure themselves on the sharp cleaver, the cleavers may not be switched correctly, or, even worse, someone could trip and fall while holding the sharp meat cleaver.

While this play has several complicated sequences of violence within it, in production, this would be one of the simplest productions for which to fully realize and stage violence. No guns are fired during the play, so a dummy rubber gun could easily be used in place of a blank-firing gun in all the sequences. Most of the violence in the play is unarmed violence, so it would be a matter of teaching proper unarmed techniques to convincingly stage the violence for the audience to believe it is "real." To support the transgression of the gender performances of the characters in this play, I would opt for a realistic staging of all the violence rather than abstracting the violence to support the gender subversion of the characters. This would largely depend on the "victims" of the violence to convincingly portray pain as a result of the violent acts, which would in turn reinforce in the audience's mind the image of woman as she who punishes and harms rather than she who nurtures and comforts (especially her children or other family members).

\section{Implications for Further Research}


The interest in women performing acts of violence is a burgeoning line of inquiry within the theatre world. What I hope this study does is bring forth another type of violence that is being presented on the American stage - and, so far, given less attention, which is aggressive acts of violence initiated and committed by women. These are not victims, or not exclusively victims. These are not characters who are only reacting to violence enacted upon them by men. These are women characters who, for the most part, are agents in their own story, and, in some cases, even reclaim the narrative from the male gaze. These characters subvert the gendered expectations and cultural norms of American society to satirize and critique and undermine those expectations. These plays are complex and challenging in terms of technology, staging violence, narrative, tone, and potential meanings, so I hope this dissertation aids those who want to take on the challenge of studying and staging them.

These playwrights represent a new generation of third wave feminist women playwrights whose critiques of American society and culture warrant further investigation; others may have differing interpretations of these portrayals of brutality, violence, sexual assault, misogyny, capitalism, and discrimination regardless of the context of the works. In addition, these works are mostly focused on gender, but also have an eye towards how socioeconomic status and capitalism intersect and impact women's lives. The women in these plays are mostly in heterosexual relationships. Other research examining women playwrights of color and/or queer women playwrights could explore these intersections as well as critical race, decolonial, and queer theory to examine how other points of intersectional identity may further subvert or destabilize gender performance. International playwrights' works may also be useful in comparing 
and contrasting the impact the cultural norms and societal values have on these disruptions of gender (if they even are disruptions in other cultures). In addition, more research is needed on the intersections of gender, violence, and race in works like these (in which all the characters are White) different from "gender norms" for women of color.

In addition to looking at the content and contexts of the plays, more research should be done surrounding the form and structure of works by Callaghan and Wegrzyn. These women use exceedingly dark humor (specifically in relation to violence, sexual assault, and misogyny) to bring about social change or raise awareness of the plight of women. In fact, both playwrights have specifically categorized these works as "comedies." With a growing body of literature and theory on women, comedy, and the use of humor, these theories could also be applied to women playwrights' comedies and dark comedies to evaluate the intention and efficacy of these comic strategies. Some other women playwrights' works that would be worthy of exploration in a similar model would be Rebecca Gilman, Cherrie Moraga, Naomi Wallace, Hannah Moscovitch, Naomi lizuka, and Sarah Kane.

Finally, more research needs to be done on violence relative to women's experience with violence as aggressors. The literature overwhelmingly profiles women as victims, but what does it mean when women are the aggressors? Theories and understandings of when, why, and how women are violent, and treating violence as behavior and not as a biologically determined attribute, is crucial in investigating violence in the future. 


\section{BIBLIOGRAPHY}

Abrams, Jamie R. "The Feminist Case for Acknowledging Women's Acts of Violence." Yale Journal of Law and Feminism 27, no. 2 (2016): 45.

Acker, Joan. "Hierarchies, Jobs, Bodies: A Theory of Gendered Organizations." Gender \& Society 4, no. 2 (June 1990): 139-158.

Auger, Micheline. "Theaterspeak : Clubbed Thumb's Maria Striar Talks About The Development of Sheila Callaghan's Interesting New Play, Roadkill Confidential." Theatrespeak, n.d. Accessed February 17, 2019. http://www.theaterspeak.org/2010/09/its-sort-of-one-of-those-things-where.html.

Austin, Gayle. "Feminist Literary Criticism: The 'Resisting Reader."' In Feminist Theories for Dramatic Criticism, 21-37. Ann Arbor: University of Michigan Press, 1990.

Barson, Michael. "Martin Scorsese | Biography, Films, \& Facts." Encyclopedia Britannica. Accessed March 27, 2019. https://www.britannica.com/biography/Martin-Scorsese.

. "Woody Allen | Biography, Movies, \& Facts." Encyclopedia Britannica. Accessed March 27, 2019. https://www.britannica.com/biography/Woody-Allen.

Batrinos, Menelaos L. "Testosterone and Aggressive Behavior in Man." International Journal of Endocrinology \& Metabolism 10, no. 3 (June 1, 2012): 563-568.

Beare, Margaret. Women and Organized Crime. Canada: Research and National Coordination Organized Crime Division, Law Enforcement and Policy Branch, Public Safety Canada, 2010.

Behn, Aphra. "The Rover; or, the Banish'd Cavaliers." Project Gutenberg. Accessed November 7, 2018. https://www.gutenberg.org/files/21339/21339$\mathrm{h} /$ files/rover.html.

Beltrán, Gina Jimena. "Violence and Performance on the Latin American Stage." Dissertation, University of Toronto, 2012.

Berger, John. Ways of Seeing. London: The British Broadcasting Corporation and Penguin Books, 1972.

Bernard Shaw, George. "Pygmalion." Project Gutenberg. Accessed November 7, 2018. https://www.gutenberg.org/files/3825/3825-h/3825-h.htm\#act4.

Biernat, Monica, and Amanda K. Sesko. "Gender Stereotypes and Stereotyping: A Cognitive Perspective on Gender Bias." In Gender, Sex, \& Sexualities: Psychological Perspectives, edited by Nancy K. Dess, Jeanne Marecek, and Leslie C. Bell, 171-194. New York: Oxford University Press, 2018. 
Brasherfons, Lukas. "Unlimited Passion: The Opposing Schools of Stage Violence in Shakespeare and Kane.” Thesis, University of Iowa, 2017.

Bray, John Patrick. "Playwright as Auteur, Playwright as Producer: The Economics and Aesthetics of the Twenty-First Century American Playwright." New England Theatre Journal 23 (August 2012): 57-78.

Brockett, Oscar G., and Franklin J. Hildy. "European Theatre in the Middle Ages." In History of Theatre, 72-107. 9th ed. Boston: Allyn and Bacon, 2003.

Bryan, Richard A. "From the Voice to the Violent Act: Language and Violence in Contemporary Drama." Dissertation, University of Tennessee - Knoxville, 2006.

Busselle, Kate. "When Oppressed Women Attack: Female-Enacted Violence through Minority American Female Playwrights' Works." Thesis, University of Central Florida, 2015.

Butler, Isaac. "Chronicle of an Award Ungiven." American Theatre 28, no. 1 (January 2011): 106.

Butler, Judith. Bodies That Matter: On the Discursive Limits of "Sex." New York: Routledge, 1993.

- Gender Trouble: Feminism and the Subversion of Identity. 2nd ed. New York: Routledge, 1990.

Callaghan, Sheila. "Preface." In Lascivious Something, Roadkill Confidential, That Pretty Pretty; or, the Rape Play: Three Plays, xiii-xv. Berkeley, CA: Soft Skull Press, 2011.

_. "Roadkill Confidential." In Lascivious Something, Roadkill Confidential, That Pretty Pretty; or, the Rape Play: Three Plays, 109-228. Berkeley, CA: Soft Skull Press, 2011.

_ . "That Pretty Pretty; Or, the Rape Play." In Lascivious Something, Roadkill Confidential, That Pretty Pretty; Or, the Rape Play: Three Plays, 229-231. Berkeley, CA: Soft Skull Press, 2011.

Campbell, Mike. "Meaning, Origin and History of the Name Donald." Behind the Name. Accessed April 18, 2019. https://www.behindthename.com/name/donald.

_- "Meaning, Origin and History of the Name Eoghan." Behind the Name. Accessed March 24, 2019. https://www.behindthename.com/name/eoghan.

. "Meaning, Origin and History of the Name Raymond." Behind the Name. Accessed April 5, 2019. https://www.behindthename.com/name/raymond. 
Caron, Christina. "Students Who Made Apparent Nazi Salute in Photo Won't Be Punished." The New York Times, December 11, 2018, sec. U.S. Accessed April 20, 2019. https://www.nytimes.com/2018/11/24/us/baraboo-wisconsin-nazisalute-photo.html.

Carrington, Kerry. "Girls and Violence: The Case for a Feminist Theory of Female Violence." International Journal for Crime, Justice, and Social Democracy 2, no. 2 (2013): 63-79.

Carroll, Linda J., and J. Peter Rothe. "Viewing Vehicular Violence through a Wide Angle Lens: Contributing Factors and a Proposed Framework." Canadian Journal of Criminology and Criminal Justice 56, no. 2 (February 2014): 149-166.

Castellun, Maida. "The Plays That Pass." New York Call. New York, April 30, 1922, sec. 4.

Catino, Maurizio. "Mafia Rules. The Role of Criminal Codes in Mafia Organizations." Scandinavian Journal of Management 31, no. 4 (2015): 536-548.

Cayli, Baris. "Performance Matters More than Masculinity: Violence, Gender Dynamics and Mafia Women." Aggression and Violent Behavior 29 (2016): 36-42.

Ceballos Muñoz, Alfonso, Ramón Espejo Romero, and Bernardo Muñoz Martínez, eds. Violence in American Drama: Essays on Its Staging, Meanings and Effects. Jefferson, North Carolina: McFarland, 2011.

Cieply, Michael. "Godard's Hononary Oscar Raises Charges of Anti-Semitism.” The New York Times, November 1, 2010, sec. Movies. Accessed March 27, 2019. https://www.nytimes.com/2010/11/02/movies/02godard.html.

Colletta, Lisa. "Postmodernity and the Use of Political Satire." In Women and Comedy: History, Theory, Practice, edited by Diana Solomon, Sean Zwagerman, Paul Matthew St. Pierre, Peter Dickinson, and Anne Higgins, 207-218. Madison: Fairleigh Dickinson University Press, 2014. Accessed May 1, 2019. http://search.ebscohost.com.proxy.mul.missouri.edu/login.aspx?direct=true \&db=n lebk\&AN=753604\&site=eds-live \&scope=site.

Cooper, Alexia, and Erica L Smith. "Homicide Trends in the United States, 1980-2008" (2011): 36.

Coward, Noel. Private Lives: An Intimate Comedy in Three Acts. New York: Samuel French, 1947.

Dillon, Michele, and Sarah Savage. "Values and Religion in Rural America: Attitudes toward Abortion and Same-Sex Relations" (2004): 10.

Dolan, Jill. The Feminist Spectator as Critic. 2nd ed. Ann Arbor: University of Michigan Press, 1988. 
Douglas, Mary. Purity and Danger: An Analysis of the Concepts of Pollution and Taboo. London: Routledge, 1966.

Dowler, Kenneth, and Bruce Arai. "Stress, Gender and Policing: The Impact of Perceived Gender Discrimination on Symptoms of Stress." International Journal of Police Science \& Management 10, no. 2 (2008): 123.

Duke, Lynne. “The FBI's Art Attack: Offbeat Materials at Professor's Home Set Off Bioterror Alarm.” The Washington Post. Washington, DC, June 2, 2004.

Dworkin, Andrea. "Renouncing Sexual 'Equality." off our backs: a women's newsjournal 4, no. 11 (1974): 2.

Editors. "My Lai Massacre.” HISTORY. Accessed April 28, 2019. https://www.history.com/topics/vietnam-war/my-lai-massacre-1.

Editors, History.com. “Jane Fonda's First Workout Video Released.” HISTORY. Accessed March 27, 2019. https://www.history.com/this-day-in-history/janefondas-first-workout-video-released.

Esslin, Martin. "The Theatre of the Absurd." The Tulane Drama Review 4, no. 4 (May 1960): 3-15.

Fox, James Alan, and Emma E. Fridel. "Gender Differences in Patterns and Trends in U.S. Homicide, 1976-2015.” Violence and Gender 4, no. 2 (June 2017): 37-43.

Fox, John, and Bob Pease. "Military Deployment, Masculinity and Trauma: Reviewing the Connections." Journal of Men's Studies 20, no. 1 (January 2012): 16-31.

Goff, Jennifer Ann. “'if More Women Knew More Jokes...’: The Comic Dramaturgy of Sarah Ruhl And Sheila Callaghan.” Dissertation, Wayne State University, 2015.

Grote, Jason. “Joyce Among the Ruins.” American Theatre 23, no. 5 (June 5, 2006): 2222.

Harbison, Lawrence. 2014: The Best Women's Stage Monologues, 2014.

- New Playwrights: The Best Plays of 2008. Hanover, N.H.: Smith and Kraus, 2008.

—. The Best Men's Stage Monologues. 2017, 2017.

—. The Best Women's Stage Monologues. 2017, 2017.

- The Best Women's Stage Monologues of 2008. Hanover, NH: Smith \& Kraus, 2009.

Hart, Sarah. "Sheila Callaghan Writes Plays with One Finger on the Fast-Forward Button." American Theatre (October 2008): 28-30. 
Herbert, Joe. "Without Testosterone, Would There Be War?" Psychology Today. Accessed November 10, 2018.

https://www.psychologytoday.com/blog/hormones-and-the-brain/201603/withouttestosterone-would-there-be-war.

Hinojosa, Ramon. "Doing Hegemony: Military, Men, and Constructing a Hegemonic Masculinity." Journal of Men's Studies 18, no. 2 (2010): 179-194.

Jordan, Kelda Lynn. "Perspectives on Women and Aggression Illustrated Through Caryl Churchill's Top Girls, Maria Irene Fornes' Fefu and Her Friends, and Sheila Callaghan's That Pretty Pretty; or, The Rape Play.” Thesis, California State University, Sacramento, 2010.

Karius, Megan. "Understanding Abjection: An Analysis of the Monstrous-Feminine in the Art of Cindy Sherman." MK Feminist, December 31, 2011. Accessed April 30, 2019. http://megankarius.com/academic-papers/abjection-cindy-sherman/.

Kaye, Sandy. "JelloWrestling.Com.” Accessed March 28, 2019. https://fun.jellowrestling.com/jellowrestling-homepage.

Kimmel, Michael S. The Gender of Desire: Essays on Male Sexuality. Albany, NY: State University of New York Press, 2005.

http://proxy.mul.missouri.edu/login?url=http://search.ebscohost.com/login.aspx?d irect $=$ true $\& \mathrm{db}=$ nlebk $\& A N=144997 \&$ site $=$ eds-live $\&$ scope $=$ site .

Knowles, Wesley B. Organized Crime in the U.S. Criminal Justice, Law Enforcement and Corrections Series. New York: Nova Science Publishers, Inc, 2010. http://proxy.mul.missouri.edu/login?url=http://search.ebscohost.com/login.aspx?d irect $=$ true $\& \mathrm{db}=$ nlebk $\& A N=387208 \&$ site $=$ eds-live $\&$ scope $=$ site .

Krefting, Rebecca. All Joking Aside: American Humor and Its Discontents. Baltimore: Johns Hopkins University Press, 2014. http://proxy.mul.missouri.edu/login?url=http://search.ebscohost.com/login.aspx?d irect=true $\& \mathrm{db}=\mathrm{e} 700 \times \mathrm{xna} \& \mathrm{AN}=778025 \&$ site $=$ eds-live $\&$ scope $=$ site .

Kristeva, Julia. Powers of Horror: An Essay on Abjection. Translated by Leon S. Roudiez. New York: Columbia University Press, 1982. Accessed April 26, 2019. http://www.jstor.org/stable/3684782?origin=crossref.

Lee, Bandy X. "Causes and Cures II: The Biology of Violence." Aggression and Violent Behavior 25 (November 1, 2015): 204-209.

Lee, Felicia R. "Wasserstein Prize Goes to Playwright, 28." The New York Times, December 1, 2009, sec. Theater. Accessed September 17, 2018. https://www.nytimes.com/2009/12/02/theater/02artsWASSERSTEINP_BRF.html. 
Litke, Robert F. "Violence and Power." In Violence: A Philosophical Anthology, edited by Vittorio Bufacchi, 296-308. New York: Palgrave Macmillan, 2009.

MacKenzie, Sarah Emily. "White Settler Colonialism and (Re)Presentations of Gendered Violence in Indigenous Women's Theatre." Dissertation, University of Ottowa, 2016.

Massie, Courtney Alimine. "Toward a Theatre of Empathy: Violence in the Plays of Timberlake Wertenbaker, Sarah Kane, and Marina Carr." University of Texas at Austin, 2017.

McAfee, Noelle. Julia Kristeva. Routledge Critical Thinkers. New York: Routledge, 2004.

McDonald, M. M., C. D. Navarrete, and M. Van Vugt. "Evolution and the Psychology of Intergroup Conflict: The Male Warrior Hypothesis." Philosophical Transactions of the Royal Society B: Biological Sciences 367, no. 1589 (March 5, 2012): 670679.

McKelvie, Melissa, and Steven R. Gold. "Hyperfemininity: Further Definition of the Construct." Journal of Sex Research 31, no. 3 (September 1994): 219.

Mikkelson, David. "FACT CHECK: Guillermo Vargas: Dog Starved for Art Exhibit." Snopes.Com. Accessed March 20, 2019. https://www.snopes.com/factcheck/starving-dog-art/.

Morgan, Michael H., and David R. Carrier. "Protective Buttressing of the Human Fist and the Evolution of Hominin Hands." The Journal of Experimental Biology 216, no. 2 (January 15, 2013): 236.

Mosher, Donald L, and Mark Sirkin. "Measuring a Macho Personality Constellation." Journal of Research in Personality 18, no. 2 (June 1984): 150-163.

Mulvey, Laura. "Visual Pleasure and Narrative Cinema." In Film Theory and Criticism: Introductory Readings, edited by Leo Braudy and Marshall Cohen, 833-844. New York: Oxford University Press, 1999.

Murnen, Sarah K., and Donn Byrne. "Hyperfemininity: Measurement and Initial Validation of the Construct." Journal of Sex Research 28, no. 3 (August 1991): 479.

Mychaskiw, Marianne. "This Is Why People Cut Off Their Hair After a Breakup." InStyle. Last modified October 10, 2016. Accessed April 29, 2019. https://www.instyle.com/news/haircut-breakup-connection.

Nevitt, Lucy. Theatre \& Violence. Theatre\&. Palgrave Macmillan, 2013. 
Niehoff, Debra. The Biology of Violence: How Understanding the Brain, Behavior, and Environment Can Break the Vicious Circle of Aggression. New York: The Free Press, 1999.

Nuendorf, Henri. "Study: $80 \%$ of Artists Represented at NYC's Top Galleries Are White." Artnet News. Last modified June 2, 2017. Accessed February 20, 2019. https://news.artnet.com/art-world/new-york-galleries-study-979049.

Ozieblo, Barbara, and Noelia Hernando-Real, eds. Performing Gender Violence: Plays by Contemporary American Women Dramatists. 1st ed. New York: Palgrave Macmillan, 2012.

Pan, Deanna. "A Guide to Mass Shootings in America." Mother Jones, n.d. Accessed November 10, 2018. https://www.motherjones.com/politics/2012/07/massshootings-map/.

Phillips, Robert. “Abjection.” TSQ: Transgender Studies Quarterly 1, no. 1-2 (May 1, 2014): 19-21.

Pizzini-Gambetta, Valeria. "Organized Crime: The Gender Constraints of Illegal Markets." In The Oxford Handbook of Gender, Sex, and Crime, edited by Rosemary Gartner and Bill McCarthy, 448-467. New York: Oxford University Press, 2014.

Press, The Associated. "Charge Dropped Against Artist in Terror Case." The New York Times, April 22, 2008, sec. N.Y. / Region. Accessed February 17, 2019. https://www.nytimes.com/2008/04/22/nyregion/22bioart.html.

Pringle, Rosemary, and Susan Collings. "Women and Butchery: Some Cultural Taboos." Australian Feminist Studies 8, no. 17 (March 1993): 29-45.

Rabe-Hemp, Cara E. "POLICEwomen or PoliceWOMEN?: Doing Gender and Police Work." Feminist Criminology 4, no. 2 (April 2009): 114-129.

Rigg, Khary K., Steven P. Kurtz, and Hilary L. Surratt. "Patterns of Prescription Medication Diversion among Drug Dealers." Drugs: Education, Prevention and Policy 19, no. 2 (April 2012): 145-155.

Rodgers, J.T. "Deep Conditioning: An Interview with the Playwright." American Theatre, April 2009.

Rogers, J. T. “Deep Conditioning.” American Theatre 26, no. 4 (April 2009): 78-79.

Rothe, J. Peter. Driven to Kill: Vehicles as Weapons. Alberta, Canada: The University of Alberta Press, 2008.

__. "Introduction." In Driven to Kill: Vehicles as Weapons, 1-7. Alberta, Canada: The University of Alberta Press, 2008. 
_. "Section I: The Social Context." In Driven to Kill: Vehicles as Weapons, 9-10. Alberta, Canada: The University of Alberta Press, 2008.

_- "Violence Against Nature." In Driven to Kill: Vehicles as Weapons, 73-80. Alberta, Canada: The University of Alberta Press, 2008.

Salmi, Jamil. "The Different Categories of Violence." In Violence: A Philosophical Anthology, edited by Vittorio Bufacchi, 311-319. New York: Palgrave Macmillan, 2009.

Serratore, Nicole. "The Kilroys Were Here (at the Lillys' Behest)." American Theatre 32, no. 5 (June 5, 2015): 12-13.

Shakespeare, William. "The Tragedy of Macbeth.” Accessed May 3, 2019. http://shakespeare.mit.edu/macbeth/full.html.

Shane, Tim. "Commedia Stock Characters Columbina." Accessed October 14, 2018. http://www.tim-shane.com/Commedia-Columbina.htm.

Smith, Kirsten. "Seduction and Sex: The Changing Allure of the Femme Fatale in Fact and Fiction." At the Interface / Probing the Boundaries, no. 90 (September 2017): $37-52$.

Sontag, Susan. "Notes on Camp." In Theater of the Avant-Garde 1950-2000: A Critical Anthology, edited by Robert Knopf and Julia Listengarten, 312-324. New Haven: Yale University Press, 2011.

Sorrentino, Renee, Susan Hatters Friedman, and Ryan Hall. "Gender Considerations in Violence." Psychiatric Clinics of North America 39, no. 4 (December 2016): 701710.

Straus, Murray A. "Discipline and Deviance: Physical Punishment of Children and Violence and Other Crime in Adulthood." Social Problems 38, no. 2 (1991): 133.

Szlawieniec-Haw, Danielle. "The Consequences of Representing Human Suffering, Distress, and/or Violence.” Dissertation, York University, 2018.

Taylor Porter, Nancy. Violent Women in Contemporary Theatre: Staging Resistance. New York: Palgrave Macmillan, 2017.

The Kilroys. The Kilroys List: 97 Monologues and Scenes by Female and Trans Playwrights. Edited by Anna Feinberg. Vol. 1. New York: Theatre Communications Group, Inc., 2017.

Ward, Elizabeth M., MS, and RD. "The Truth About Bread and Your Diet." WebMD. Accessed March 28, 2019. https://www.webmd.com/diet/features/truth-aboutbread-and-diet. 
Wegrzyn, Marisa. “@howdymarisa.” Social Media, n.d. Accessed April 6, 2019. https://twitter.com/howdymarisa.

—. Killing Women. New York: Broadway Play Publishing Inc., 2014.

—_. "Marisa Wegrzyn's CHAINSAW CALLIGRAPHY." Chainsaw Calligraphy, n.d. Accessed April 6, 2019. http://chainsawcalligraphy.blogspot.com/.

—.The Butcher of Baraboo. New York: Broadway Play Publishing Inc., 2015.

White, Clair, Justin Ready, and Charles M. Katz. "Examining How Prescription Drugs Are Illegally Obtained: Social and Ecological Predictors." Journal of Drug Issues 46, no. 1 (January 2016): 4-23.

Wilson, August. "The Ground on Which I Stand." In The American Theatre Reader: Essays and Conversations from American Theatre Magazine, 152-162. New York: Theatre Communications Group, Inc., 2009.

Wright, Tessa. Gender and Sexuality in Male-Dominated Occupations: Women Working in Construction and Transport. London: Palgrave Macmillan, 2016.

"5 Professions Ruled by Women | Fortune.” Accessed April 27, 2019. http://fortune.com/2013/03/11/5-professions-ruled-by-women/.

“Abby: Name Meaning, Popularity, and Similar Names.” Accessed April 5, 2019. https://nameberry.com/babyname/Abby.

“About.” The Kilroys. Last modified June 11, 2015. Accessed January 4, 2019. https://thekilroys.org/about/.

“Awards and Prizes." American Theatre 24, no. 10 (December 2007): 20-21.

"Bio." Sheila Callaghan., August 28, 2018. Accessed September 17, 2018. https://www.sheilacallaghan.com/bio/.

"Black Widows on the Web." Psychology Today. Accessed April 26, 2019. http://www.psychologytoday.com/blog/the-human-equation/201210/blackwidows-the-web.

"Boy or Girl? Gender Popularity of the Name 'Trevor." Accessed April 24, 2019. http://www.babynameshub.com/gendercompare.cfm?Name=Trevor.

“Bread, Symbolism of | Encyclopedia.Com.” Accessed March 28, 2019. https://www.encyclopedia.com/food/encyclopedias-almanacs-transcripts-andmaps/bread-symbolism.

“Everytown for Gun Safety.” Everytown for Gun Safety. Accessed November 10, 2018. https://everytown.org/learn/. 
"Femme Fatale, n." OED Online. Oxford University Press, n.d. Accessed April 28, 2019. http://www.oed.com.proxy.mul.missouri.edu/view/Entry/291008.

“Gun Violence.” Amnesty International USA. Accessed November 10, 2018. https://www.amnestyusa.org/issues/gun-violence/.

"Gun Violence in America." EverytownResearch.Org. Last modified July 19, 2018. Accessed March 27, 2019. https://everytownresearch.org/gun-violence-america/.

"How Common Is PTSD in Women? - PTSD: National Center for PTSD." General Information. Accessed April 24, 2019. https://www.ptsd.va.gov/understand/common/common_women.asp.

“Interview with Marisa Wegrzyn | Steppenwolf Theatre.” Accessed September 5, 2018. https://www.steppenwolf.org/articles/interview-with-marisa-wegrzyn/.

"Jane Fonda | Biography, Facts, Films, \& Activism." Encyclopedia Britannica. Accessed March 24, 2019. https://www.britannica.com/biography/Jane-Fonda.

"Lucy: Name Meaning, Popularity, and Similar Names.” Accessed April 5, 2019. https://nameberry.com/babyname/Lucy.

“Mansplaining | Merriam-Webster.” Accessed June 30, 2019. https://www.merriamwebster.com/words-at-play/mansplaining-definition-history.

“Marisa Wegrzyn.” IMDb. Accessed September 17, 2018. http://www.imdb.com/name/nm5794137/.

“Marisa Wegrzyn | Playscripts, Inc.” Accessed September 17, 2018. https://www.playscripts.com/playwrights/bios/867.

"Meaning, Origin and History of the Name Agnes - Behind the Name." Accessed March 24, 2019. https://www.behindthename.com/name/agnes.

"Meaning, Origin and History of the Name Michael - Behind the Name." Accessed April 5, 2019. https://www.behindthename.com/name/michael.

"Mel Gibson." Biography. Accessed March 27, 2019. https://www.biography.com/people/mel-gibson-9310680.

“Midge | Insect.” Encyclopedia Britannica. Accessed April 27, 2019. https://www.britannica.com/animal/midge.

"Midges." Accessed April 27, 2019. https://www.insectidentification.org/insectdescription.asp?identification=Midges.

"Mythology and Folklore of Yew | Trees for Life." Accessed March 26, 2019. https://treesforlife.org.uk/forest/mythology-folklore/yew/. 
“NIMH » Post-Traumatic Stress Disorder.” Accessed February 20, 2019. https://www.nimh.nih.gov/health/topics/post-traumatic-stress-disorderptsd/index.shtml.

“Overview for Martin Scorsese.” Turner Classic Movies. Accessed March 27, 2019. http://www.tcm.com/tcmdb/person/172836|108079/Martin-Scorsese/.

“Owen Name Meaning \& Origin.” Baby Name Wizard. Accessed March 24, 2019. http://www.babynamewizard.com/baby-name/boy/owen.

"Persons Arrested." FBI 2017 Crime in the United States. Accessed October 16, 2018. https://ucr.fbi.gov/crime-in-the-u.s/2017/crime-in-the-u.s.-2017/topicpages/persons-arrested.

"Pratt Name Meaning, Family History, Family Crest \& Coats of Arms." HouseOfNames. Accessed December 9, 2018. https://www.houseofnames.com/pratt-family-crest.

"Pretty, Adj., n., and Int." OED Online. Oxford University Press, n.d. Accessed May 1, 2019. http://www.oed.com.proxy.mul.missouri.edu/view/Entry/151023.

"Rodney Name Meaning \& Rodney Family History at Ancestry.Com." Accessed March 24, 2019. https://www.ancestry.com/name-origin?surname=rodney.

"Sander Name Meaning \& Sander Family History at Ancestry.Com." Accessed April 5, 2019. https://www.ancestry.com/name-origin?surname=sander.

"Second Amendment | Wex Legal Dictionary / Encyclopedia | LII / Legal Information Institute." Accessed November 10, 2018. https://www.law.cornell.edu/wex/second_amendment.

“Sheila Callaghan." IMDb. Accessed September 17, 2018. http://www.imdb.com/name/nm3558363/.

"Statistics." The National Domestic Violence Hotline. Accessed March 28, 2019. https://www.thehotline.org/resources/statistics/.

“The Numbers - Top-Grossing Movies of 2018.” Accessed March 26, 2019. https://www.the-numbers.com/market/2018/top-grossing-movies.

"Trevor Name Meaning \& Trevor Family History at Ancestry.Com." Accessed December 9, 2018. https://www.ancestry.com/name-origin?surname=trevor.

“"Twin Peaks' Proves David Lynch Still Has a Woman Problem (Commentary)." TheWrap. Last modified May 31, 2017. Accessed April 28, 2019. https://www.thewrap.com/twin-peaks-david-lynch-woman-problem/.

"U.S. Census Bureau QuickFacts: Baraboo City, Wisconsin.” Accessed September 16, 2018. https://www.census.gov/quickfacts/baraboocitywisconsin?\#qf-headnote-a. 
"Valerie Name Meaning \& Origin." Baby Name Wizard. Accessed March 24, 2019. http://www.babynamewizard.com/baby-name/girl/valerie.

"Violence, n." OED Online. Oxford University Press, n.d. Accessed September 3, 2018. http://www.oed.com.proxy.mul.missouri.edu/view/Entry/223638.

"Violent Crime." FBI 2017 Crime in the United States. Accessed October 16, 2018. https://ucr.fbi.gov/crime-in-the-u.s/2017/crime-in-the-u.s.-2017/topicpages/violent-crime.

"Why We Hide Emotional Pain | Psychology Today." Accessed March 28, 2019. https://www.psychologytoday.com/us/blog/evolution-the-self/201109/why-wehide-emotional-pain. 


\section{VITA}

Kate Busselle is a theatre educator, scholar, violence and intimacy designer, director, and actor. She received her BFA in Acting from Michigan State University, her MA in Theatre Studies from the University of Central Florida, and her PhD in Theatre and Performance Studies from the University of Missouri.

Kate has two research agendas: theatrical violence and theatrical intimacy. While her dissertation specifically focused on theatrical violence, Kate is also an independent intimacy designer who has taught several workshops on staging intimacy, as well as designing intimacy for several productions. Her specific area of expertise is staging sexual trauma and assault and how to assist actors in leaving these moments behind in the theatre. She is a co-founder of Theatrical Intimacy Education and the founder of Heartland Intimacy Design and Training.

Kate is an Actor Combatant with the Society of American Fight Directors (SAFD) with certifications in unarmed combat, rapier \& dagger, quarterstaff, single sword, broadsword, broadsword and shield, knife, and theatrical firearms safety. She is also a member of the Association of Movement Theatre Educators (ATME), Association for Theatre in Higher Education (ATHE).

Kate is also a director, primarily directing new student-written work, play reading festivals, and regional semi-professional theatre. She is an Equity Membership Candidate (EMC) with the Actors Equity Association (AEA). 